\title{
Results from the Long-Term Interaction and Modeling of SRL-131 Glass with Aqueous Solutions
}

D. M. Strachan

L. R. Pederson

R. O. Lokken

November 1985

Prepared for the U.S. Department of Energy under Contract DE-AC06-76RLO 1830

Pacific Northwest Laboratory Operated for the U.S. Department of Energy by Battelle Memorial Institute 


\title{
DISCLAIMER
}

This report was prepared as an account of work sponsored by an agency of the United States Government. Neither the United States Government nor any agency thereof, nor any of their employees, makes any warranty, express or implied, or assumes any legal liability or responsibility for the accuracy, completeness, or usefulness of any information, apparatus, product, or process disclosed, or represents that its use would not infringe privately owned rights. Reference herein to any specific commercial product, process, or service by trade name, trademark, manufacturer, or otherwise, does not necessarily constitute or imply its endorsement, recommendation, or favoring by the United States Government or any agency thereof. The views and opinions of authors expressed herein do not necessarily state or reflect those of the United States Government or any agency thereof.

\author{
PACIFIC NORTHWEST LABORATORY \\ operated by \\ BATTELLE \\ for the \\ UNITED STATES DEPARTMENT OF ENERGY \\ under Contract DE-AC06-76RLO 1830
}

\begin{tabular}{|c|c|}
\hline \multirow{2}{*}{\multicolumn{2}{|c|}{ Printed in the United States of America }} \\
\hline & \\
\hline \\
\hline \multicolumn{2}{|c|}{ United States Department of Commerce } \\
\hline 5285 & oad \\
\hline \multicolumn{2}{|c|}{ Springfield, Virginia 22161} \\
\hline \multicolumn{2}{|c|}{ NTIS Price Codes } \\
\hline \multicolumn{2}{|c|}{ Microfiche A01 } \\
\hline \multicolumn{2}{|c|}{ Printed Copy } \\
\hline & \\
\hline Pages & Codes \\
\hline $001-025$ & A02 \\
\hline 026-050 & $\mathrm{A} 03$ \\
\hline 051-075 & AO4 \\
\hline 076-100 & A05 \\
\hline $101-125$ & A06 \\
\hline $126-150$ & $\mathrm{~A} 07$ \\
\hline $151-175$ & $A 0 B$ \\
\hline $176-200$ & $\mathrm{~A} 09$ \\
\hline $201-225$ & A010 \\
\hline $226-250$ & A011 \\
\hline $251-275$ & A012 \\
\hline $276-300$ & A013 \\
\hline
\end{tabular}


PNL -5654

UC -70

RESULTS FROM THE LONG-TERM INTERACTION

AND MODELING OF SRL-131 GLASS WITH

AQUEOUS SOLUTIONS

D. M. Strachan

L. R. Pederson

R. 0. Lokken

November 1985

Prepared for

the U.S. Department of Energy

under Contract DE-AC06-76RLO 1830

Pacific Northwest Laboratory

Richland, Washington 99352 
$\checkmark$ 


\begin{abstract}
Leaching studies on SRL-131 simulated defense waste glass have been carried out for a duration of two years. This glass contained nonradioactive elements and depleted uranium to simulate the waste content. The leachants used in this study were deionized water, a sodium bicarbonate/silicic acid solution (silicate water), a synthetic groundwater, and a high ionic strength $\mathrm{K}-\mathrm{Mg}-\mathrm{Na}-\mathrm{Cl}$ brine. Two temperatures were used; $40^{\circ} \mathrm{C}$ and $90^{\circ} \mathrm{C}$. The long-term results were in fair agreement with modeling calculations performed using the PHREEOE geochemical code. The leachabitity of SRL-131 glass from results up to two years followed the trend: deionized water > silicate water > synthetic groundwater $>$ salt brine at $40^{\circ} \mathrm{C}$ and deionized water $\cong$ synthetic groundwater > silicate water $>5$ alt brine at $90^{\circ} \mathrm{C}$. Solid state analyses are reported along with an Appendix containing a complete data set.
\end{abstract}




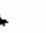
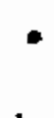
ABSTRACT $\ldots \ldots \ldots \ldots \ldots \ldots \ldots \ldots \ldots \ldots \ldots \ldots \ldots \ldots \ldots \ldots \ldots \ldots \ldots \ldots \ldots \ldots \ldots \ldots \ldots \ldots \ldots \ldots$

inTRODUCTION $\ldots \ldots \ldots \ldots \ldots \ldots \ldots \ldots \ldots \ldots \ldots \ldots \ldots \ldots \ldots \ldots \ldots \ldots \ldots \ldots \ldots \ldots \ldots \ldots$

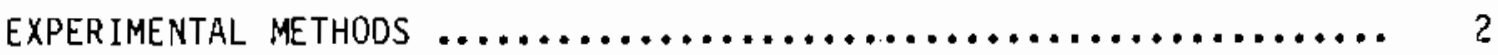

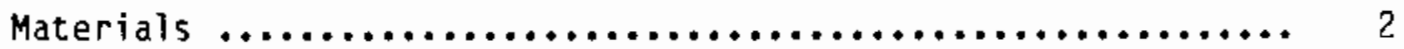

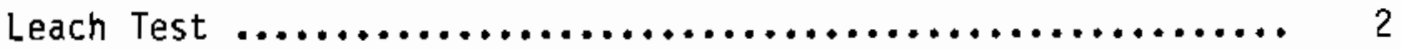

Solid State Analyses $\ldots \ldots \ldots \ldots \ldots \ldots \ldots \ldots \ldots \ldots \ldots \ldots \ldots \ldots \ldots \ldots$

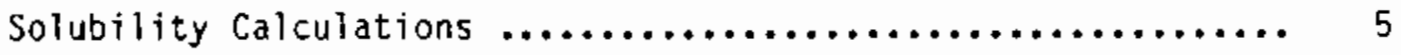

RESULTS AND DISCUSSIDN $\ldots \ldots \ldots \ldots \ldots \ldots \ldots \ldots \ldots \ldots \ldots \ldots \ldots \ldots \ldots \ldots \ldots \ldots \ldots \ldots \ldots \ldots \ldots \ldots$

Deionized Water Results $\ldots . \ldots \ldots \ldots \ldots \ldots \ldots \ldots \ldots \ldots \ldots \ldots \ldots$

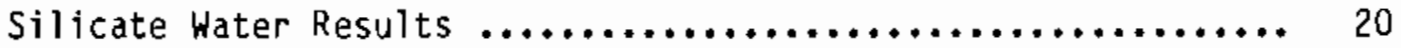

Salt Brine Results $\ldots \ldots \ldots \ldots \ldots \ldots \ldots \ldots \ldots \ldots \ldots \ldots \ldots \ldots \ldots, 32$

Synthetic Groundwater Results ..................... 42

COMPARISON OF RESULTS FROM ALL LEACHANTS $\ldots \ldots \ldots \ldots \ldots \ldots \ldots \ldots \ldots \ldots$

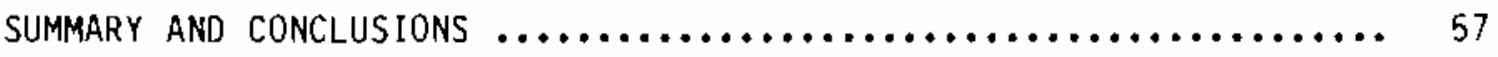

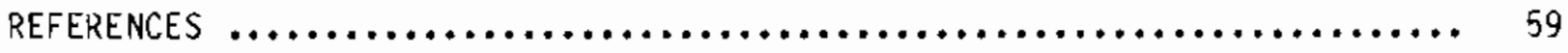

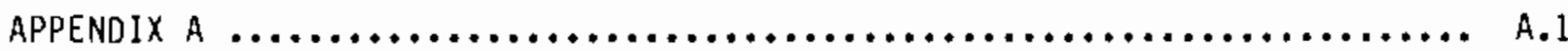




\section{FIGURES}

1 Normalized Mass Loss Results from the Leaching of SRL-131 Glass

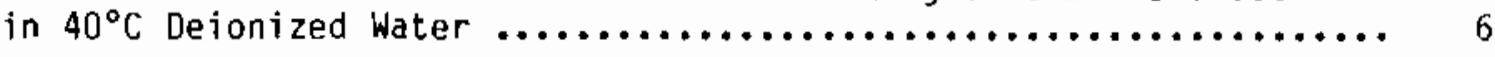

2 Normalized Mass Loss Results from the Leaching of SRL-131 Glass

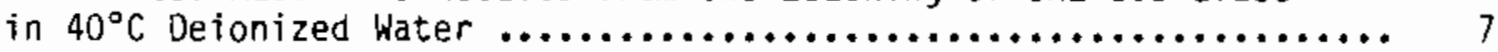

3 Normalized Mass Loss Results from the Leaching of SRL-131 Glass

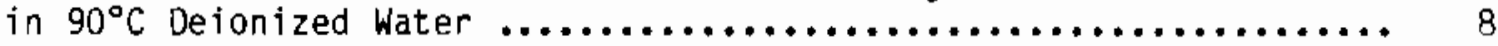

4 Normalized Mass Loss Results from the Leaching of SRL-131 Glass

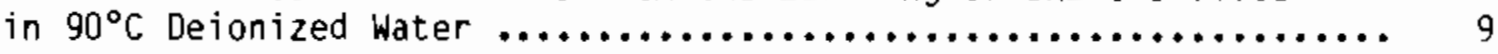

5 Leachate pH Values from SRL-131 Glass in $40^{\circ} \mathrm{C}$ Deionized Water ..... 10

6 Leachate $\mathrm{pH}$ Values from SRL-131 Glass in $90^{\circ} \mathrm{C}$ Deionized Water ...... 11

7 Photomicrographs from Specimens Leached in 0eionized Water at $40^{\circ} \mathrm{C}$ : as-leached surface, cross section ...................... 13

8 Photomicrographs from Specimens Leached in Deionized Water at $90^{\circ} \mathrm{C}$ : as-leached surface, cross section (NOTE: the $546 \mathrm{~d}$

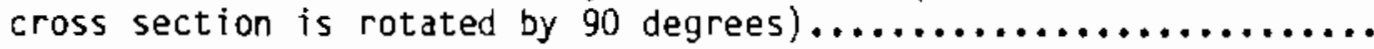

9 Calculated and Observed Data from SRL-131 Glass in Deionized

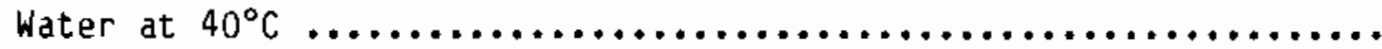

10 Calculated and Observed Data from SRL-131 Glass in Deionized

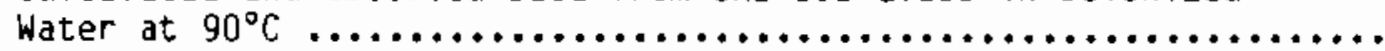

11 Normalized llass Loss Resuits from the Leaching of SRL-131 Glass

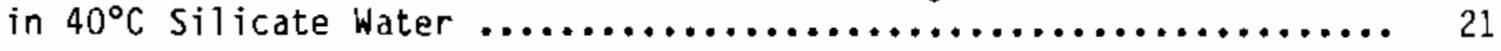

12 Normalized Mass Loss Results from the Leaching of SRL-131 Glass

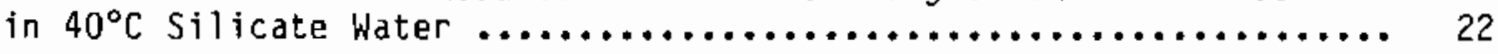

13 Normalized Mass Loss Results from the Leaching of SRL-131 Glass in $90^{\circ} \mathrm{C}$ Silicate Water ................................ 23

14 Leachate $\mathrm{pH}$ Values from SRL-131 Glass in $40^{\circ} \mathrm{C}$ silicate water ...... 25

15 Leachate $\mathrm{pH}$ Values from SRL-131 Glass in $90^{\circ} \mathrm{C}$ Silicate Water ...... 26

16 Calculated and Observed Data from SRL-131 Glass in Silicate

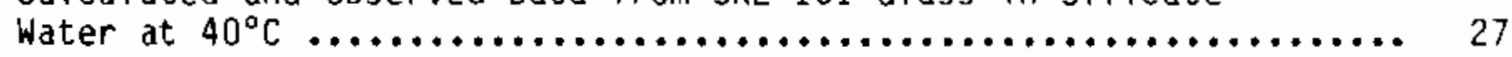

17 Calculated and Observed Data from SRL-131 Glass in Silicate Water at $90^{\circ} \mathrm{C}$ 
18 Photomicrographs from Specimens Leached in Silicate Water $40^{\circ} \mathrm{C}$ : as-leached surface, cross section ................... 30

19 Photomicrographs from Specimens Leached in Silicate Water $90^{\circ} \mathrm{C}$ : as-leached surface, cross section ................... 31

20 Normalized Mass Loss Results from the Leaching of SRL-131 Glass

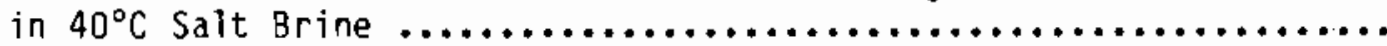

21 Normalized Mass Loss Results from the Leaching of SRL-131 Glass

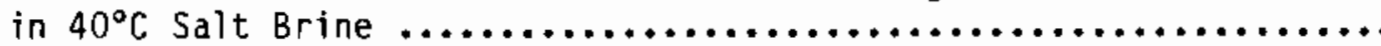

22 Normalized Mass Loss Results from the Leaching of SRL-131 Glass

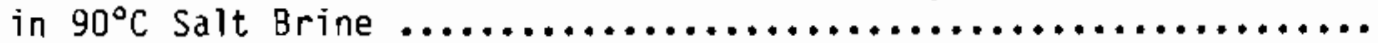

23 Leachate $\mathrm{pH}$ Values from SRL-131 Glass in $40^{\circ} \mathrm{C}$ Salt Brine ........ 36

24 Leachate $\mathrm{pH}$ Values from SRL-131 Glass in $90^{\circ} \mathrm{C}$ Salt Brine ......... 37

25 Photomicrographs from Specimens Leached in Salt Brine at $40^{\circ} \mathrm{C}$ : as-leached surface, cross section ......................... 39

26 Photomicrographs from Specimens Leached in Salt Brine at $90^{\circ} \mathrm{C}$ :

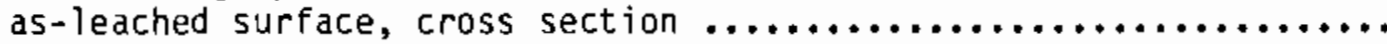

27 Nornalized Mass Loss Results from the Leaching of SRL-131 Glass

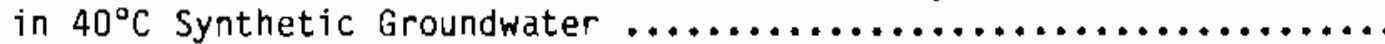

28 Normalized Mass Loss Results from the Leaching of SRL-131 Glass

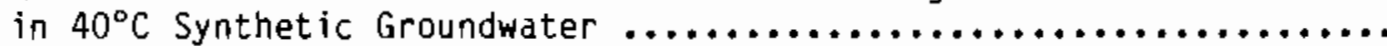

29 Normalized Mass Loss Results from the Leaching of SRL-131 Glass

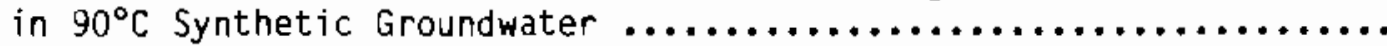

30 Normalized Mass Loss Results from the Leaching of SRL-131 Glass

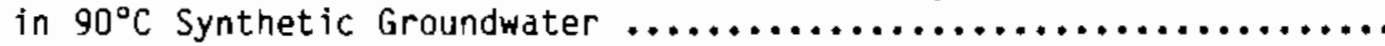

31 Leachate $\mathrm{pH}$ Values from SRL-131 Glass in $40^{\circ} \mathrm{C}$ Synthetic Ground Water .............................................

32 Leachate $\mathrm{pH}$ Values from SRL-131 Glass in $90^{\circ} \mathrm{C}$ Synthetic Ground

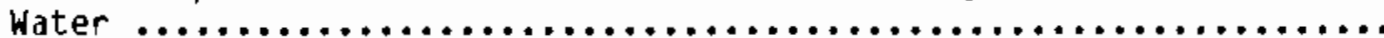

33 Photomicrographs from Specimens Leached in Synthetic Ground

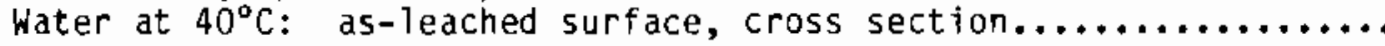

34 Photomicrographs from Specimens Leached in Synthetic Ground

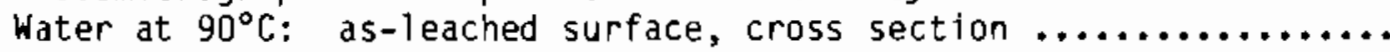

35 Calculated and Observed Data from SRL-131 Glass in Synthetic Groundwater at $40^{\circ} \mathrm{C}$ 
36 Calculated and Observed Data from SRL-13L Glass in Synthetic

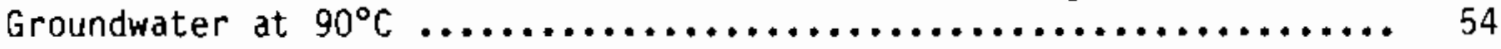

A.1 Concentrations in the Leachates from SRL-131 Glass in Deionized

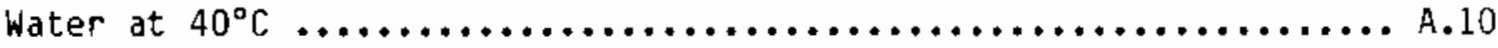

A.2 Concentrations in the Leachates from SRL-131 Glass in Deionized

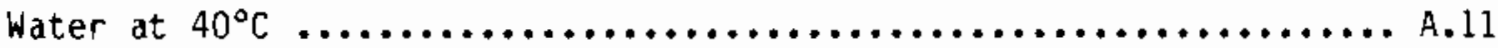

A.3 Concentrations in the Leachates from SRL-131 Glass in Deionized

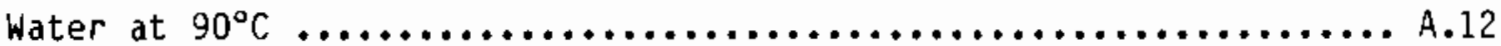

A.4 Concentrations in the Leachates from SRL-131 Glass in Deionized

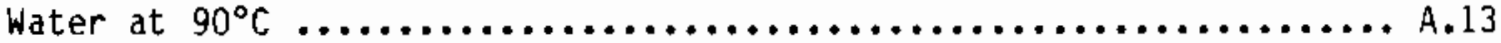

A.5 Concentrations in the Leachates from SRL-131 Glass in Silicate

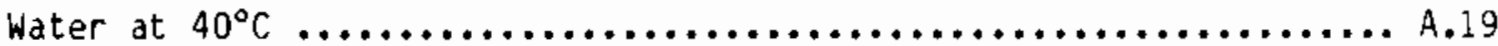

A.6 Concentrations in the Leachates from SRL-131 Glass in Silicate

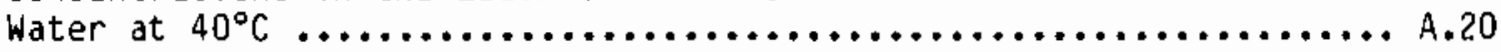

A.7 Concentrations in the Leachates from SRL-131 Glass in Silicate Water at $40^{\circ} \mathrm{C}$

A.8 Concentrations in the Leachates from SRL-131 Glass in Silicate

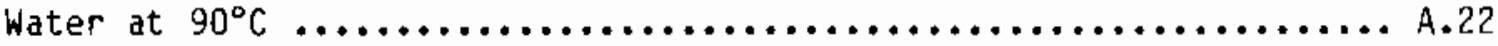

A.9 Concentrations in the Leachates from SRL-131 Glass in Silicate

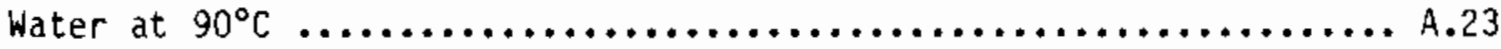

A.10 Concentrations in the Leachates from SRL-131 Glass in Salt

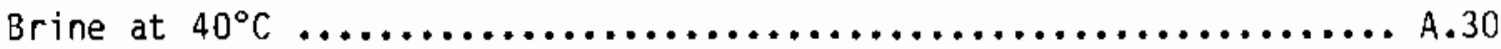

A.11 Concentrations in the Leachates from SRL-131 Glass in Salt Brine at $40^{\circ} \mathrm{C}$

A.12 Concentrations in the Leachates from SRL-131 Glass in Salt Brine at $90^{\circ} \mathrm{C}$

A.13 Concentrations in the Leachates from SRL-131 Glass in Salt Brine at $90^{\circ} \mathrm{C}$

A.14 Concentrations in the Leachates from SRL-131 Giass in Synthetic Groundwater at $40^{\circ} \mathrm{C}$

A.15 Concentrations in the Leachates from SRL-131 Glass in Synthetic Groundwater at $40^{\circ} \mathrm{C}$

A.16 Concentrations in the Leachates from SRL-131 Glass in Synthetic Groundwater at $90^{\circ} \mathrm{C}$ 
A.17 Concentrations in the Leachates from SRL-131 Glass in

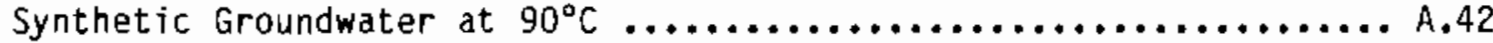




\section{TABLES}

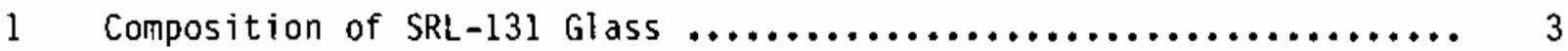

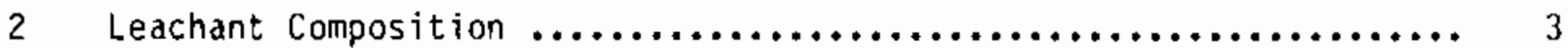

3 Test Matrix for the $2-y r$ Leach Test at $40^{\circ} \mathrm{C}$ and $90^{\circ} \mathrm{C} \ldots \ldots \ldots$

A.1 Concentrations of Elements Leached from SRL-131 Glass in

Deionized Water at $40^{\circ} \mathrm{C}$

A.2 Normalized Elemental Mass Loss for SRL-131 Glass in

Deionized Water at $40^{\circ} \mathrm{C} \ldots \ldots \ldots \ldots \ldots \ldots \ldots \ldots \ldots \ldots \ldots \ldots \ldots \ldots . \ldots \ldots$

A.3 Concentrations of Elements Leached from SRL-131 Giass in

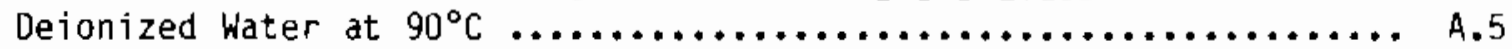

A.4 Normalized Elemental Mass Loss for SRL-131 G1ass in

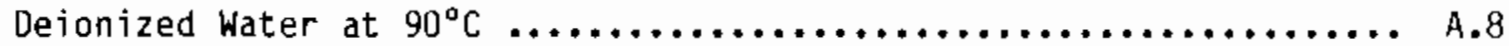

A.5 Concentrations of Elements Leached from SRL-131 Glass in

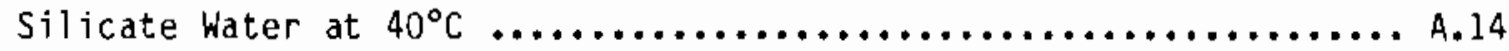

A.6 Concentrations of Elements Leached from SRL-131 Glass in

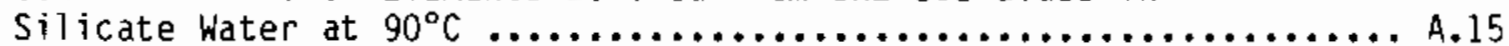

A.7 Normalized Elemental Mass Loss for SRL-131 Glass in

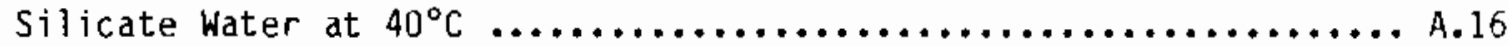

A.8 Normalized Elemental Mass Loss for SRL-131 Glass in

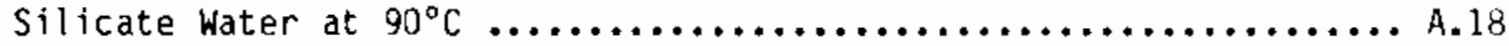

A.9 Concentrations of Elements Leached from SRL-131 Glass in

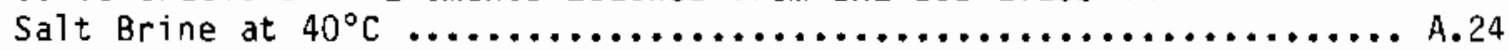

A.10 Normalized Elemental Mass Loss for SRL-131 Glass in

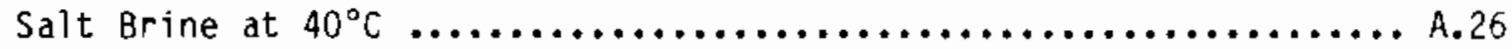

A.11 Concentrations of Elements Leached from SRL-131 Glass in

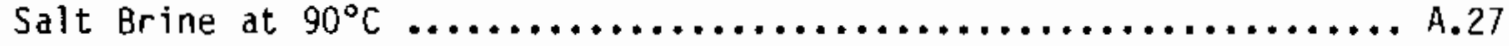

A.12 Normalized Elemental Mass Loss for SRL-131 Glass in

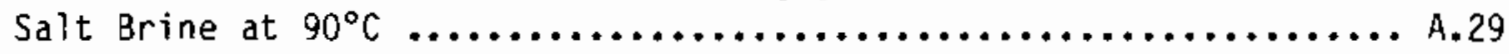

A.13 Concentrations of Elements Leached from SRL-131 Glass in

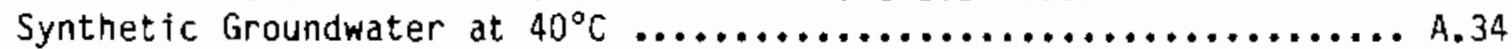

A.14 Normalized Elemental Mass Loss for SRL-131 Glass in

Synthetic Groundwater at $40^{\circ} \mathrm{C}$ 
A.15 Concentrations of Elements Leached from SRL-131 Glass in

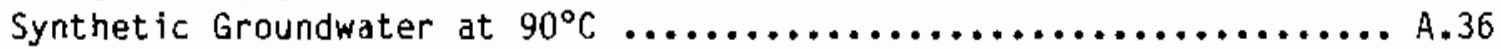

A.16 Normalized Elemental Mass Loss for SRL-131 Glass in

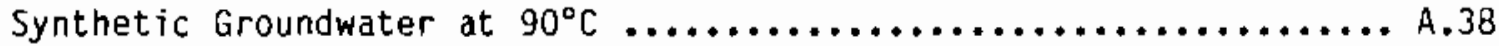


.

.

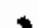

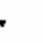


INTRODUCTION

During the various processing activities in the production of plutonium for the U.S. national defense programs, waste byproducts were generated. These wastes, which have been generated over about the past 40 years at sites such as the Savannah River Plant in South Carolina and Hanford in Washington, have been stored in underground tanks. Plans for the final disposal of the Savannah River Plant (SRP) waste have now been documented (ODE 1982) and call for the decontaminated soluble fraction of the waste to be mixed with cementitious materials and disposed of in near-surface trenches (Langton 1984). The radionuclide fraction of the soluble waste and the insoluble fraction of the waste will be converted to glass and sent to a geologic repository. In order for the repository to accept the glass, certain performance criteria must be met. Although not fully defined, it is certain that these criteria will include some specification on the rate of release of nuclides from the glass waste form when contacted by water.

To defensibly predict whether glass or any other waste form can meet anticipated radionuclide release criteria, leaching tests are needed which are carried out for times as long as possible and are coupled with modeling calculations. Modeling calculations must be based upon a physical and chemical understanding of glass-water interactions, and not merely a mathematical fit to early-time leaching data. Geochemical models can be used to predict what solution concentrations ought to be, based upon alteration product formation, their related solubilities, and groundwater complexities. These calculations can then be tested against results obtained from long-term experiments. Infortunately, the number of reported leaching experiments decreases rapidly with increased test length. Very few tests extend beyond one year. In this study, leaching experiments for a Savannah River Laboratory glass (SRL-131) were carried out to two years in four different leachants. The results were then compared to calculations using the PHREFOE geochemical code (Parkhurst, Thorstenson, and Plummer 1980).

Since the test began, the glass formulation for SRP waste has been changed from SRL-131 to SRL-165 (Soper et al 1983). Results from the long-term testing 
of SRL-131 glass will, however, still be useful in documenting the long-term performance of SRL-165. The SRL-165 glass formulation is also subject to change as adjustments are made to the overall process that will be used to treat the waste and to produce the glass.

\section{EXPERIMENTAL METHODS}

Materials

Samples of SRL-131 glass were produced at Savannah River Laboratory by melting the nonradioactive constituent oxides, carbonates, and nitrates in a laboratory-scale ceramic melter. Depleted uranium was included in the composition. After melting at $1150^{\circ} \mathrm{C}$, the molten glass was poured into $0.25 \mathrm{~L}$ stainless steel beakers. These were subsequently annealed at an unspecified temperature and time before cooling to room temperature. The as-received samples were cut into specimens of approximately $400 \mathrm{~mm}^{2}$ surface area (approximately $13 \mathrm{~mm} \times 11 \mathrm{~mm} \times 2 \mathrm{~mm}$ ), washed in an ultrasonic bath, dried, and weighed. The washes included one in acetone, one in ethanol and one in deionized water.

Randomiy selected specimens were analyzed by crushing the specimen into a fine powder and fusing a portion with $\mathrm{Na}_{2} \mathrm{O}_{2}$ and another portion with $\mathrm{KOH}$. The fusates were then dissolved in $6 \mathrm{M} \mathrm{HCL}$ and diluted to a known volume. The resulting solutions were analyzed using an Inductively Coupled Plasma Spectrometer (ICP; a Model 3560, ARL, Palo Alto, CA, or a Model Mark 8, Jarrel-Ash, Cambridge, MA). The results from these analyses are shown in Table 1. Cesium was analyzed using Atomic Absorption Spectrometry.

Leach Test

Four synthetic leachants were used in this experiment: deionized water, a silicic acid/sodium bicarbonate water, a nearly saturated salt brine, and a synthetic groundwater. The first three leachants were those recommended by the Materials Characterization Center (MCC 1981). The synthetic groundwater composition was that specified by jones (1982). The composition of these leachants, except for the deionized water (Millipore Corp.), are shown in Table 2. 
TABLE 1. Composition of SRL-131 Glass

\begin{tabular}{|c|c|c|c|}
\hline & Wto Oxide & & Wt\% 0xide \\
\hline $\mathrm{Al}_{2} \mathrm{O}_{3}$ & 3.05 & $\mathrm{MgO}$ & 1.24 \\
\hline $\mathrm{B}_{2} \mathrm{O}_{3}$ & 9.84 & $\mathrm{MnO}_{2}$ & 4.17 \\
\hline $\mathrm{BaO}$ & 0.01 & $\mathrm{Na}_{2} \mathrm{O}$ & 14.77 \\
\hline $\mathrm{CaO}$ & 1.04 & $\mathrm{Nd}_{2} \mathrm{O}_{3}$ & 0.45 \\
\hline $\mathrm{CeO}_{2}$ & 0.24 & $\mathrm{NiO}$ & 1.54 \\
\hline $\mathrm{Cr}_{2} \mathrm{O}_{3}$ & 0.18 & $\mathrm{P}_{2} \mathrm{O}_{5}$ & 0.10 \\
\hline $\mathrm{Cs}_{2} \mathrm{O}$ & 0.30 & $\mathrm{SiO}_{2}$ & 38.60 \\
\hline CuO & 0.02 & Sro & 0.14 \\
\hline $\mathrm{Fe}_{2} \mathrm{O}_{3}$ & 14.28 & $\mathrm{TiO}_{2}$ & 0.75 \\
\hline $\mathrm{K}_{2} \mathrm{O}$ & 0.12 & $\mathrm{UO}_{2}$ & 1.62 \\
\hline $\mathrm{La}_{2} \mathrm{O}_{3}$ & 0.33 & $\mathrm{ZrO}_{2}$ & 0.31 \\
\hline \multirow[t]{2}{*}{$\mathrm{Li}_{2} \mathrm{O}$} & 3.89 & & \\
\hline & & TOTAL & 97.00 \\
\hline
\end{tabular}

TABLE 2. Leachant Composition $(\mathrm{mg} / \mathrm{L})(1)$

Silicate Water Synthetic Groundwater Salt Brine

$\begin{array}{rcccrr}B(0.01) & 0.04 & - & & 17 & (0.1) \\ \mathrm{Ca}(0.01) & - & 2.4 & 302 & (0.1) \\ \mathrm{Fe}(0.005) & - & - & 0.3(0.05) \\ \mathrm{K}(0.3) & - & 3.58 & 26800 & (300) \\ \mathrm{Li}(0.004) & - & - & 35.2(0.04) \\ \mathrm{Mg}(0.06) & - & - & 30800 & (60) \\ \mathrm{Na}(0.01) & 47.9 & 364 & 34400 & (10) \\ \mathrm{Si}(0.02) & 28.9 & 30.4 & & (0.2) \\ \mathrm{Sr}(0.002) & - & 0.004 & 10(0.02)\end{array}$

(1) The numbers in parentheses are the detection limits in low ionic strength solutions ( $7 \mathrm{eft}$ ) and the salt brine (right). All concentrations shown in this table are from analyses. 
A1 though the MCC-1 Static Leach Test Method is described in detail elsewhere (MCC 1981), it is briefly described here. The specimens described above were placed in Teflon PFA jars containing a Teflon PFA specimen support and a volume of leachant equal to 10.0 times the specimen surface area. A tight-fitting lid was screwed on and the whole assembly was weighed. These jars were then placed in mechanical convection ovens (Blue $M$. Co, WI) at either $40^{\circ} \mathrm{C}$ or $90^{\circ} \mathrm{C}$. Table 3 shows the test matrix that was used. Each jar/leachant/ specimen assembly represented one data point. At the specified time a jar/ leachant/specimen was removed from the oven and weighed. The specimen was removed, washed, air dried, and weighed. The solution, now labeled the leachate, was allowed to cool to room temperature in the resealed jar. After cooling, the $\mathrm{pH}$ of an aliquot was measured using a calomel combination electrode (Orion Corp., MA).

Periodically, jar/leachant/specimen assemblies were removed from the oven and weighed. Over the two-year time period, none of the assemblies lost more than $10 \%$ of the water.

During the first six months of the test and after removal of the specimens, the leachates were acidified using concentrated acids to 1 vol\% $\mathrm{HNO}_{3}$ for the nonbrine leachants and 1 vol\% $\mathrm{HCL}$ for the brine leachants, returned to a $90^{\circ} \mathrm{C}$ oven for about 16 hours, and then analyzed. For test durations longer than six months, the leachants were filtered through 2 nm filters, acidified

TABLE 3. Test Matrix for the $2-y \mathrm{y}$ Leach Test at $40^{\circ} \mathrm{C}$ and $90^{\circ} \mathrm{C}$

Leachant/Test Duration (d) Leachant

Deionized Water

Silicate Water

Salt Brine

Synthetic Groundwater
Number

$\begin{array}{llllllllll}3 & 7 & 14 & 28 & 56 & 91 & 182 & 364 & 546 & 728\end{array}$

$\begin{array}{llllllllll}1 & 1 & 1 & 3 & 2 & 3 & 2 & 3 & 3 & 3\end{array}$

$\begin{array}{lllll}3 & 2 & 3 & 2 & 3\end{array}$

$\begin{array}{lllll}3 & 2 & 3 & 2 & 3\end{array}$

32

3

$3(a)$
Total\# of Tests.

3

$3^{(a)}$

$3^{(b)}$
22

13

19

19

(a) Leached only at $40^{\circ} \mathrm{C}$.

(b) Leached only at $90^{\circ} \mathrm{C}$. 
and analyzed. The jars were filled with a $1 \%$ acid solution, returned to the $90^{\circ} \mathrm{C}$ oven for about 16 hours, cooled, and the resulting solution analyzed.

\section{Solid State Analyses}

Selected specimens were submitted for solid state analyses. In general, these were done by carbon coating the air-dried specimen and examining the asleached surface using a SEM (JEOL, MA). These were then mounted in a thermoset resin, cut, and polished. Both SEM and Electron Microprobe (EMP; JEOL, MA) were used to analyze the specimens in cross section. Energy dispersive $x-r a y$ analyses were used in the SEM and wavelength dispersive energy analyses were used in the EMP to determine elemental profiles.

\section{Solubility Calculations}

In order to better understand the glass/water interactions, calculations similar to those performed by Grambow and Strachan (1984) were done using a modified version of the PHREEQE geochemical code (Parkhurst, Thorstenson, and Plummer 1980). The code had been modified to facilitate graphics and efficient processing of data.

\section{RESULTS AND DISCUSSION}

This section is divided into sections by leachant type, with data presented in the following order: deionized water, silicate water, salt brine, and synthetic groundwater. In each subsection both temperatures are discussed. Because the data sets are quite large, much of the data have been compiled in the appendix. An effort has been made to make this data set as complete as possible. Not all of the data from the solid state analyses could be included, however.

Selected photomicrographs of the as-leached specimens are shown in the following sections. These photomicrographs may, at first glance, be confusing. In each photomicrograph, the as-leached surface is shown on the left and the cross section on the right.

Deionized Water Results

The results from the leach tests in deionized water are summarized in Figures 1 to 6 . The complete set of analytical data are tabulated in 


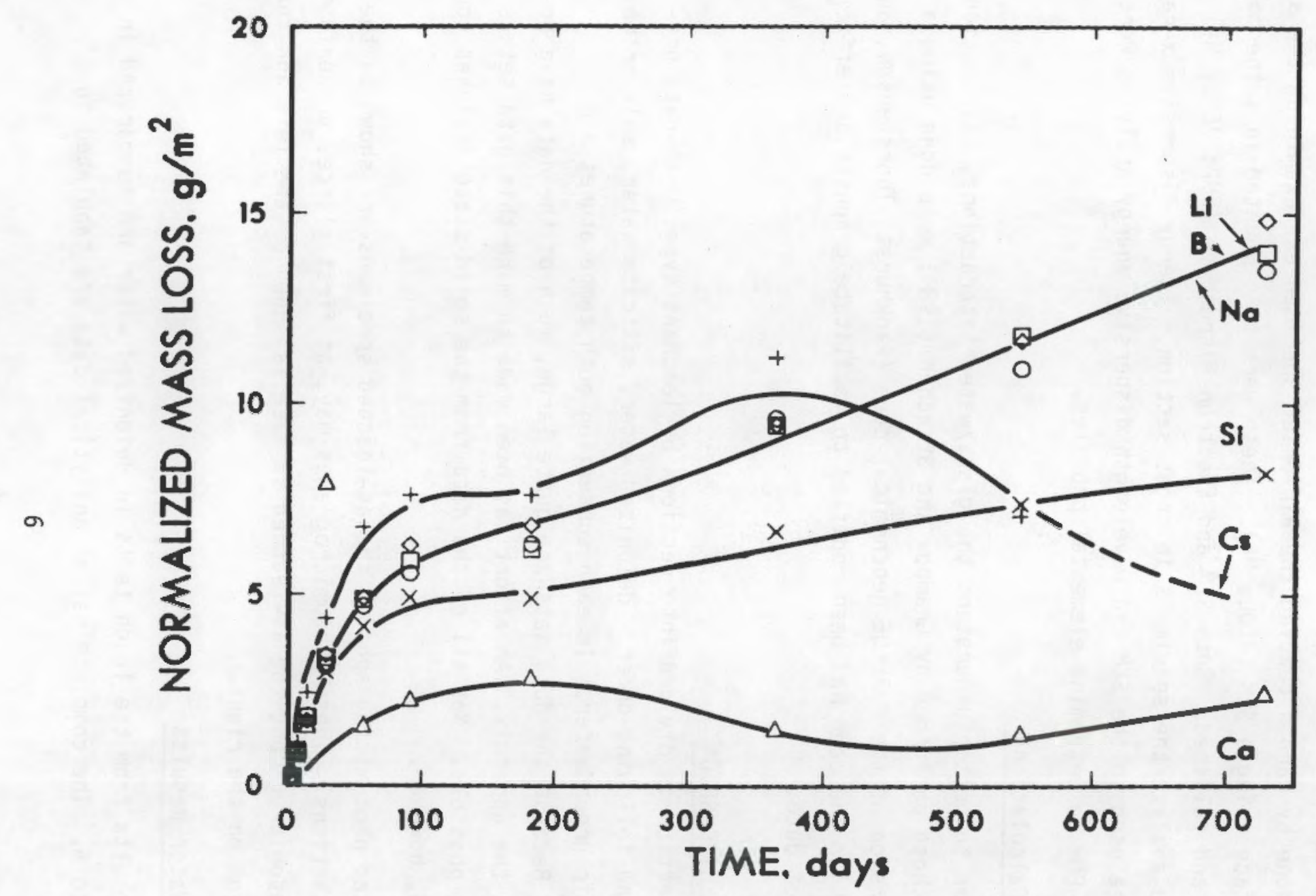

FIGURE 1. Normalized Mass Loss $\left(\mathrm{g}^{\left.-\mathrm{m}^{-3}\right)}\right.$ Results from the Leaching of SRL-131 Glass in $40^{\circ} \mathrm{C}$ Deionized Water 


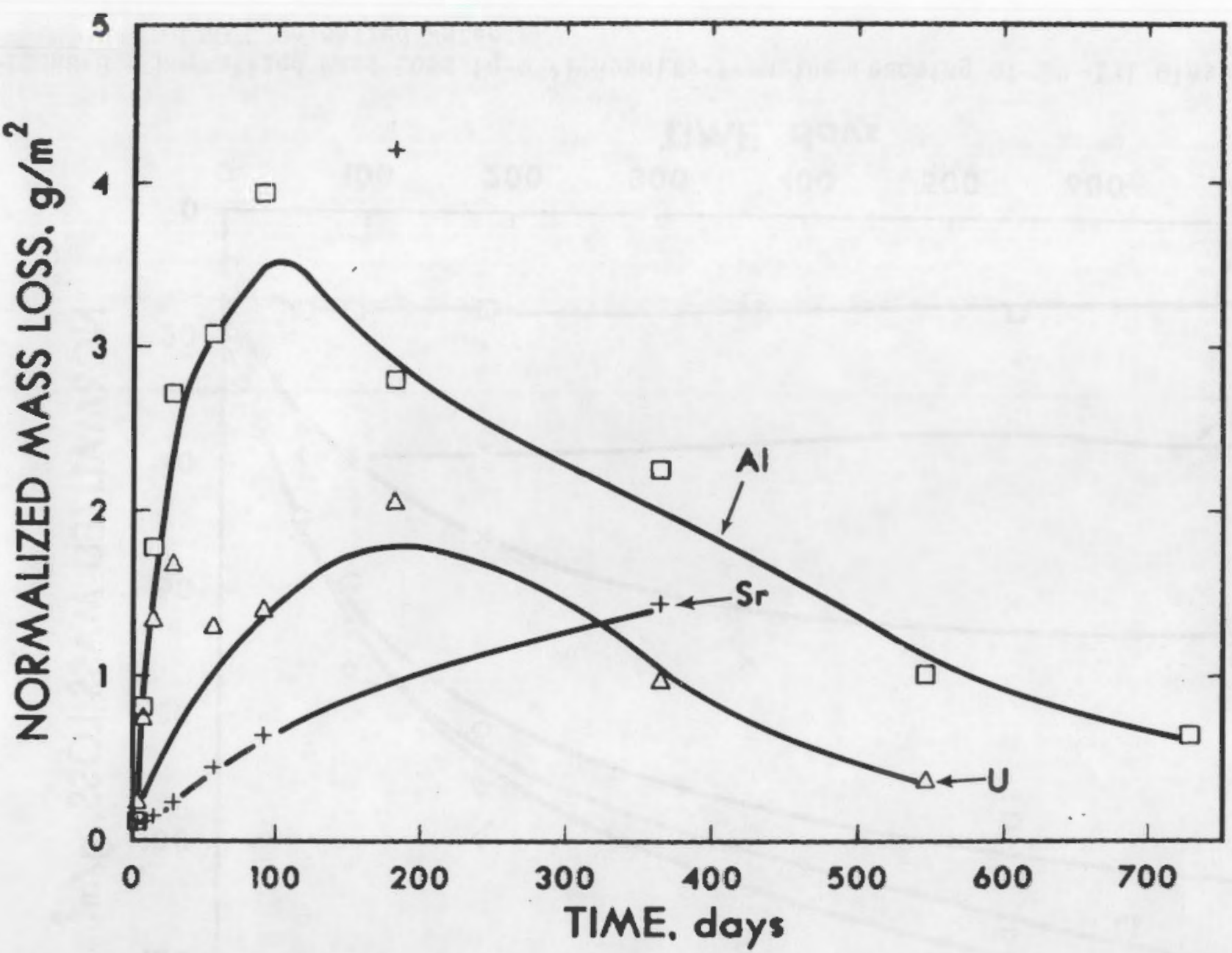

FIGURE 2. Normalized Mass Loss $\left(\mathrm{g}^{\circ} \mathrm{m}^{-3}\right)$ Results from the Leaching of SRL-131 Glass in $40^{\circ} \mathrm{C}$ Deionized Water 


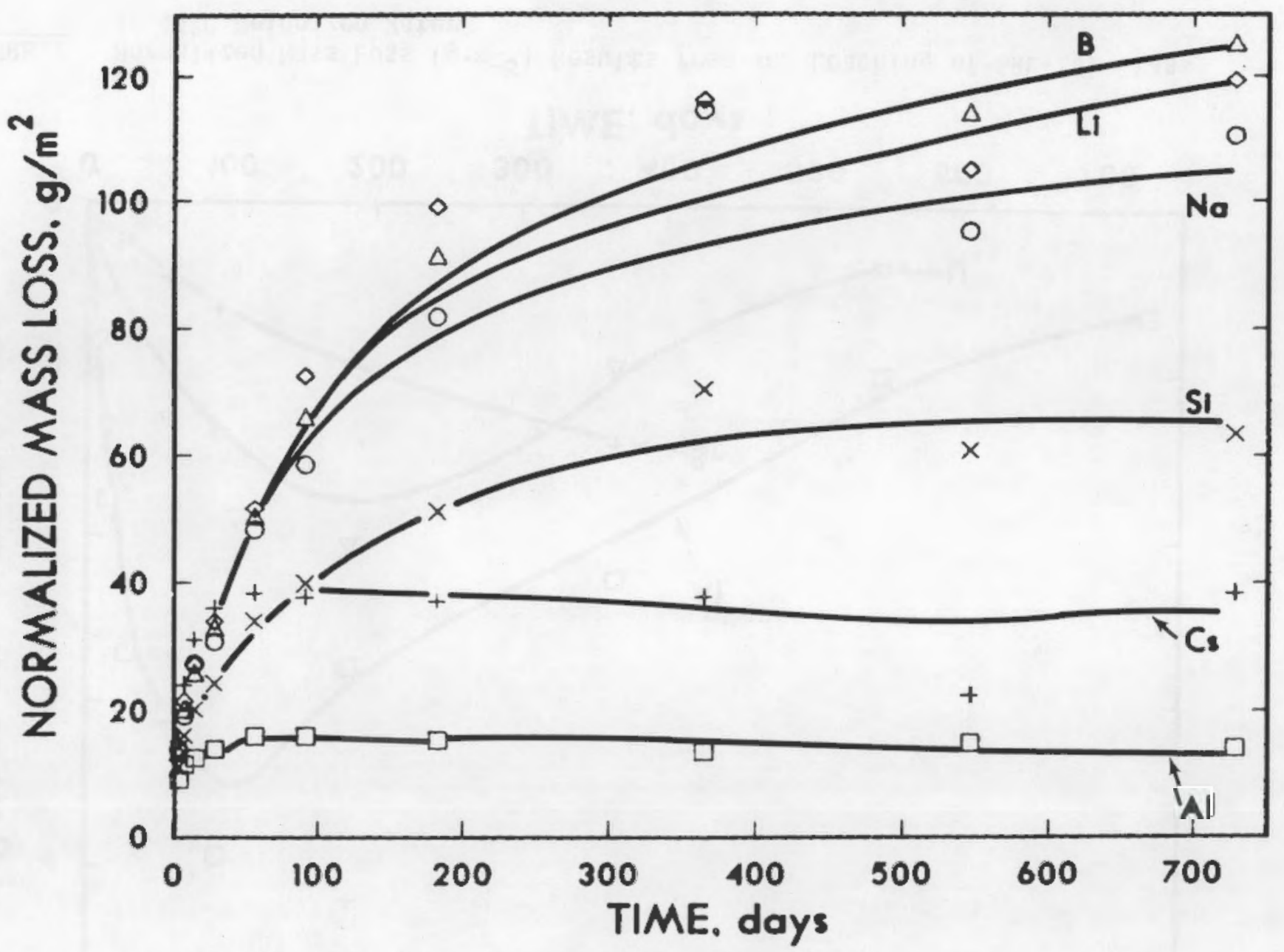

FIGURE 3. Normalized Mass Loss $\left(\mathrm{g}^{\left.-\mathrm{m}^{-3}\right)}\right.$ Results from the Leaching of SRL-131 Glass in $90^{\circ} \mathrm{C}$ Deionized Water 


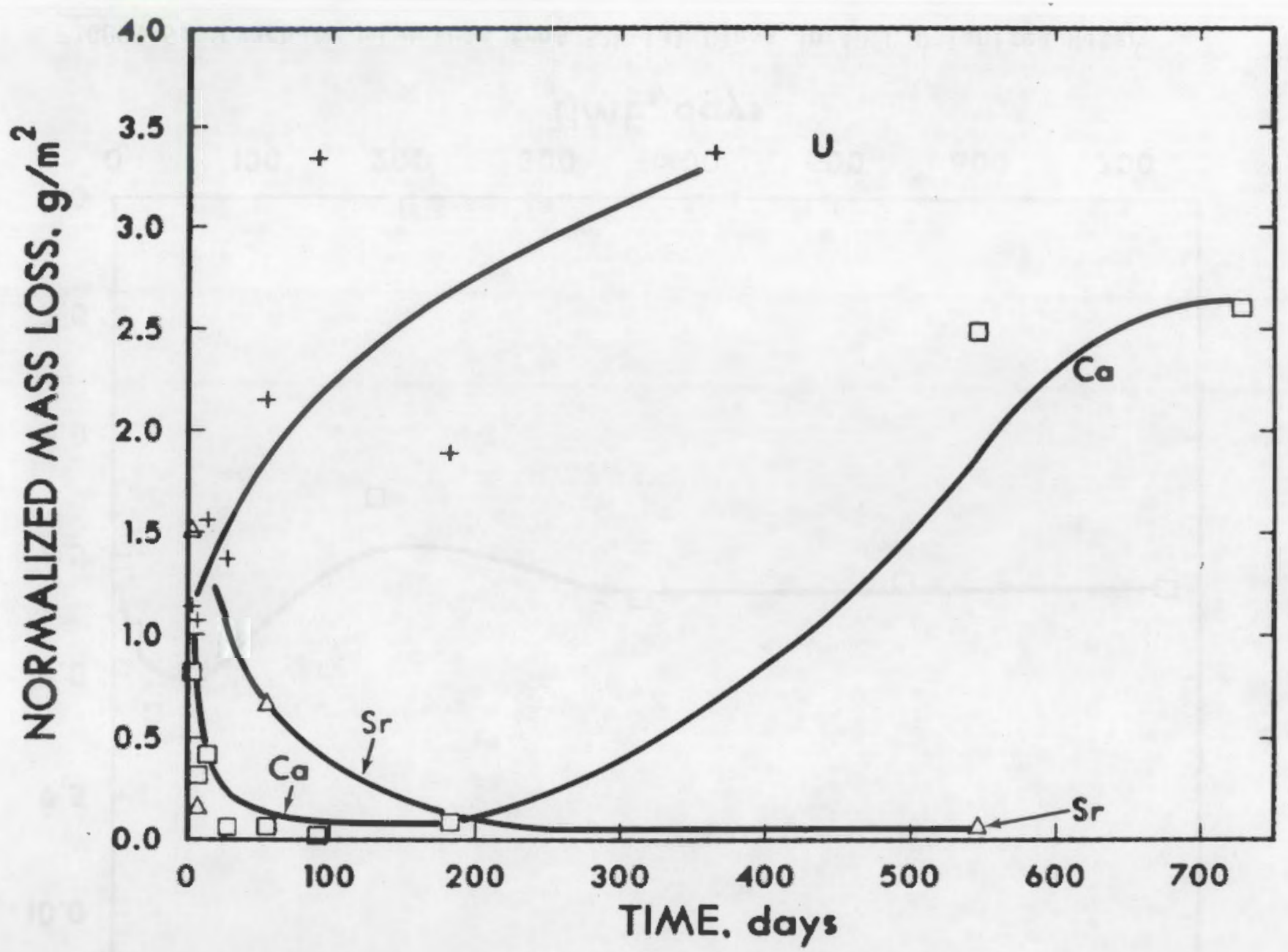

FIGURE 4. Normalized Mass Loss $\left(\mathrm{g}^{\circ} \mathrm{m}^{-3}\right)$ Results from the Leaching of SRL-131 Glass in $90^{\circ} \mathrm{C}$ Deionized Water 


\section{$40^{\circ} \mathrm{C}$ DEIONIZED WATER}

'

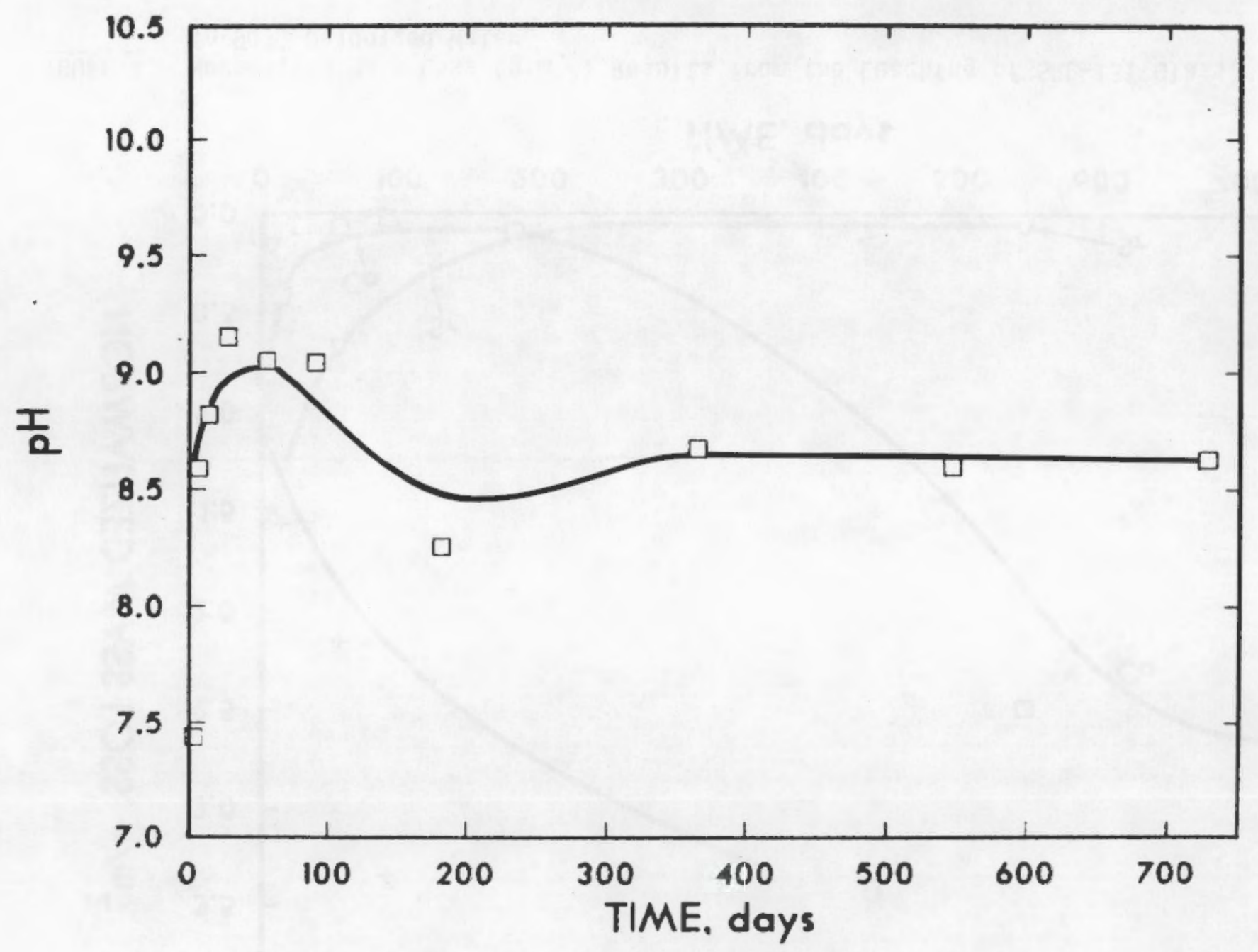

FIGURE 5. Leachate $\mathrm{pH}$ values from SRL-131 Glass in $40^{\circ} \mathrm{C}$ Deionized Water 


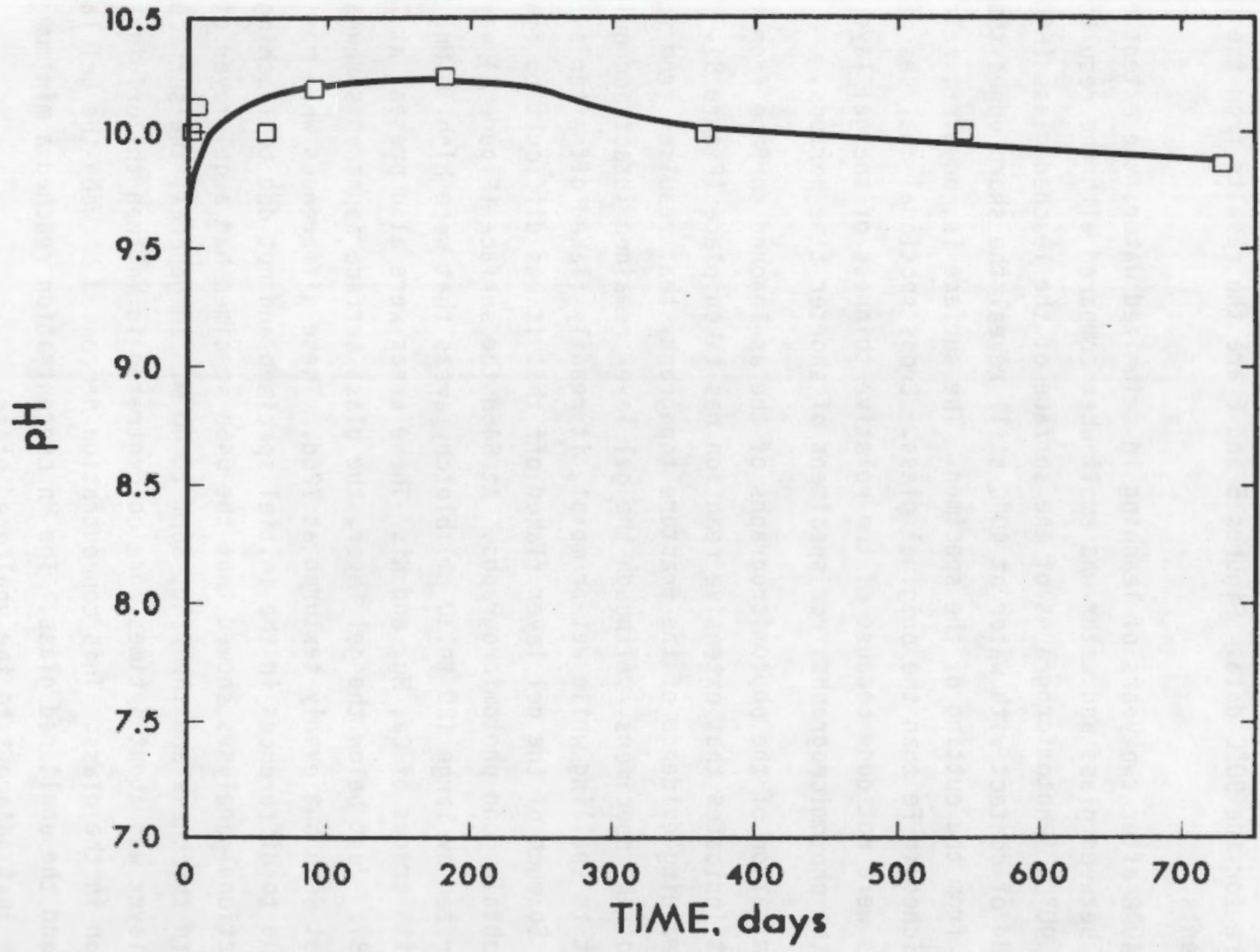

FIGURE 6. Leachate $\mathrm{pH}$ values from SRL-131 Glass in $90^{\circ} \mathrm{C}$ Deionized water 
Appendix A, Tables A.1 through A.4. Figures 1 to 4 and Tables A.3 and A.4 are compilation of the normalized elemental mass losses. Tables A.1 and A.2 and Figures $A .1$ to $A .4$ are the raw analytical data in $\mathrm{mg} / \mathrm{L}$. Figures 1,2 , and 5 , and Tables $\mathrm{A} .1$ and $\mathrm{A} .3$ give $40^{\circ} \mathrm{C}$ data, while the remainder of the plots and tables are for the $90^{\circ} \mathrm{C}$ data. Figures 5 and 6 are the results from the pH measurements.

At $40^{\circ} \mathrm{C}$ after two years of leaching in deionized water, the extent of reaction between glass and water was smal1 when compared with the results of tests at $90^{\circ} \mathrm{C}$. Photomicrographs of the surface of the leached glass (Figure 7) after $728 \mathrm{~d}$ of contact with water at $40^{\circ} \mathrm{C}$ still reveal the sharp edges that resulted from the cutting of the specimen. The surface is, however, relatively more enriched in Fe than the original glass. Cross sectional analyses of these specimens were not done because of the relative thinness of the gel layer, as seen in the photomicrographs from specimens of shorter time periods.

Examination of the photomicrographs of the as-leached surface from the $90^{\circ} \mathrm{C}$ test indicates that extensive reaction has taken place (Figure 8 ). There is no remaining evidence of the fracture topography that resulted from the cutting of the specimens. Although the gel layer remained intact and quite resistant to spalling while wet or moist, it readily flaked off after air drying. So much of the gel layer flaked off that it was difficult to find an area to obtain good photomicrographs. At 546d the surface (Figure 8) was characterized by large $(20$ to $30 \mu \mathrm{m})$ blotchy areas that were high in $\mathrm{Mn}$, Fe, and $\mathrm{Si}$ with traces of $\mathrm{Ca}, \mathrm{Mg}$, and $\mathrm{Ni}$. These areas were also present at $728 \mathrm{~d}$ (Figure 8 ). Just below the gel layer, the glass surface appeared somewhat mottled at $546 \mathrm{~d}$ but evenly textured at $728 \mathrm{~d}$. These differences were most likely due to differences in the initial specimen and not due to leaching. Cross sectional analyses showed that the $546 \mathrm{~d}$ specimen had a gel layer of $32 \mu \mathrm{m}$ to $35 \mu \mathrm{m}$ in thickness and the $728 \mathrm{~d}, 38 \mu \mathrm{m}$ to $40 \mu \mathrm{m}$. In general, the surface of the gel layer was about 5 times more concentrated in Mn than the original concentration in the glass. This concentration decreased between the gel layer surface and the unaltered glass. The Mn concentration reached a minimum in the gel layer just adjacent to the unaltered glass. 


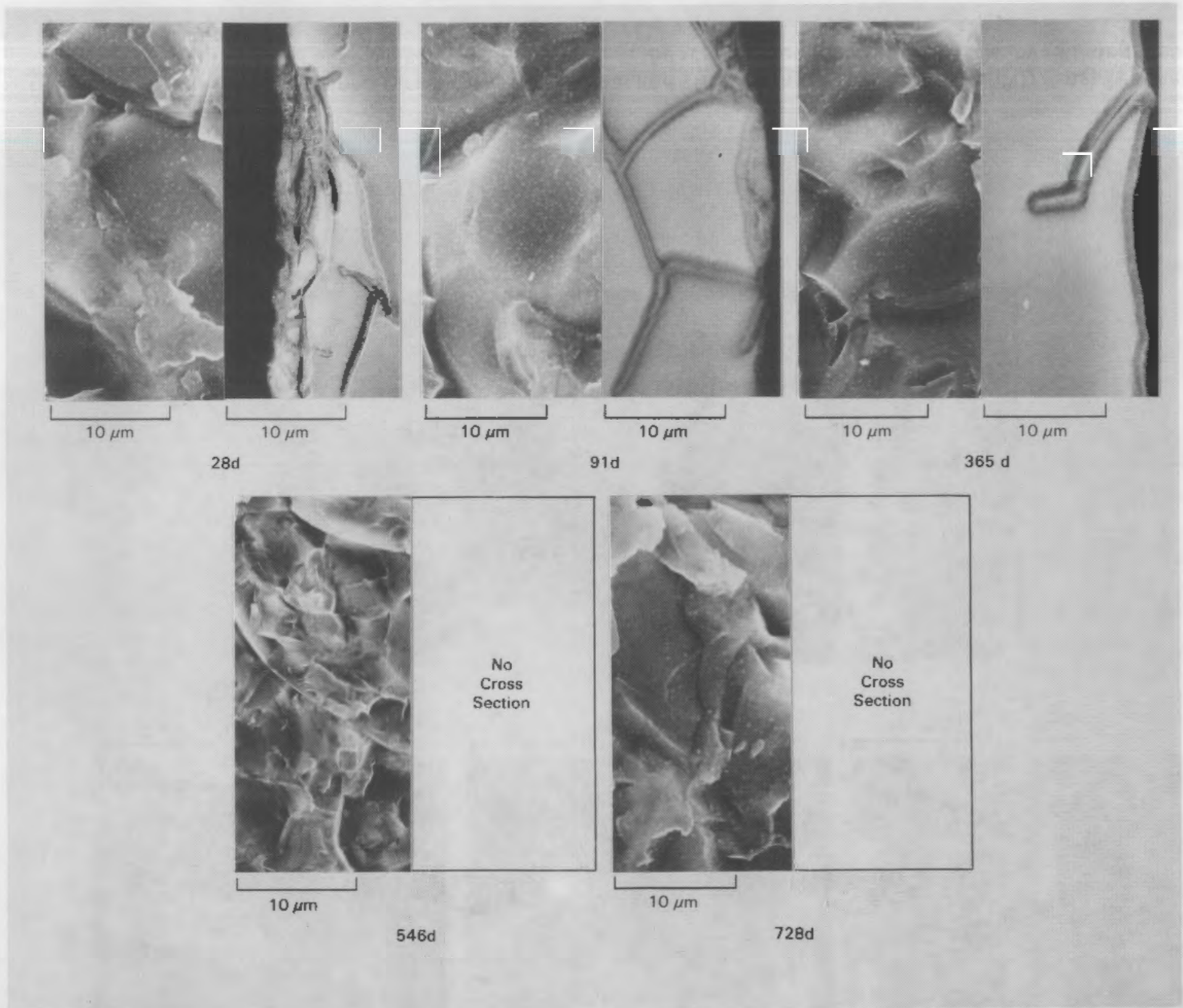

FIGURE 7. Photomicrographs from Specimens Leached in Deionized Water at $40^{\circ} \mathrm{C}$ : as-leached surface, cross section 

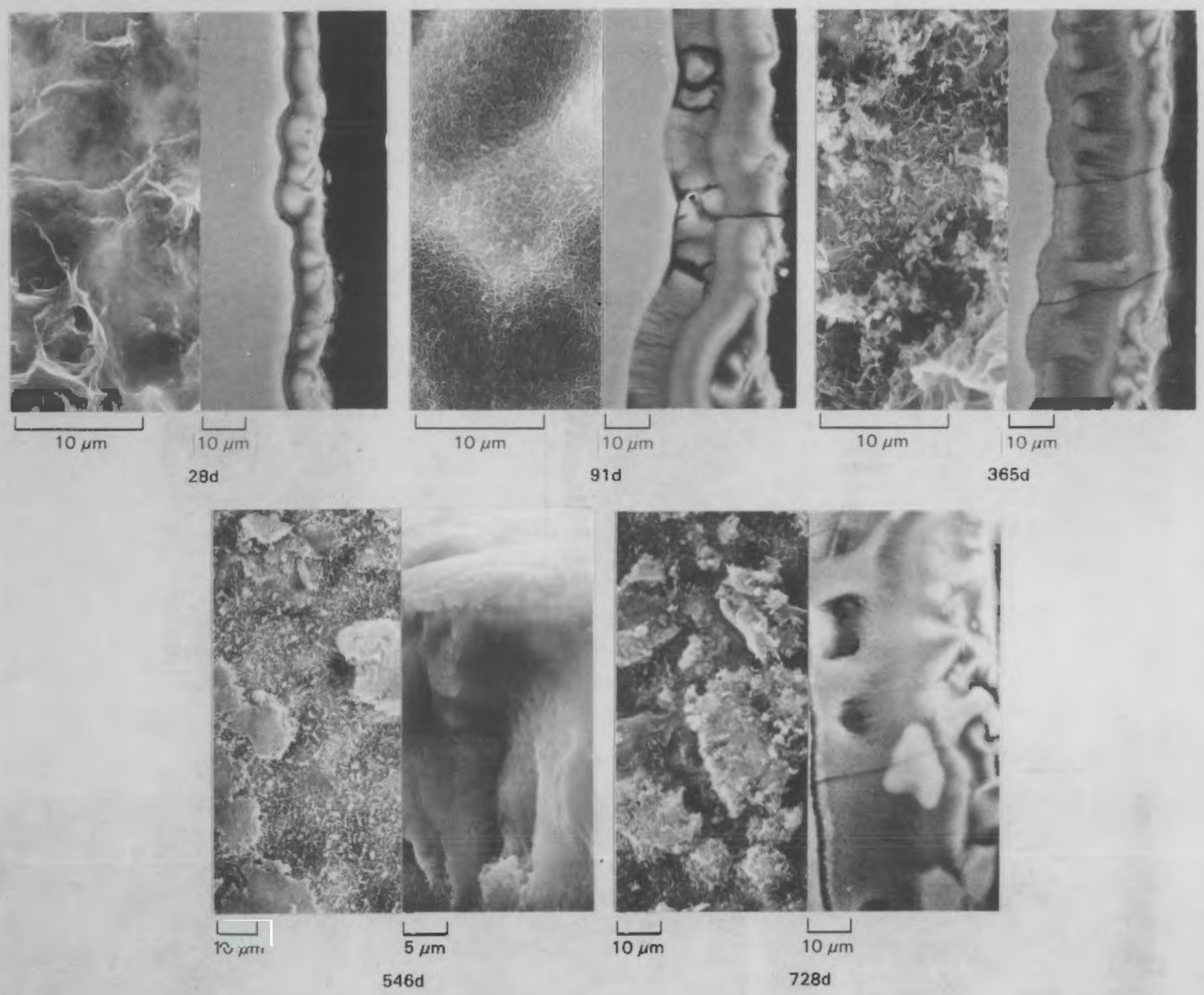

FIGURE 8. Photomicrographs from Specimens Leached in Deionized Water at $90^{\circ} \mathrm{C}$ : as-leached surface, cross section (NOTE: the $546 \mathrm{~d}$ cross section is rotated by 90 degrees) 
Al so in the gel layer just adjacent to the unaltered glass of the specimen leached for $728 \mathrm{~d}$ at $90^{\circ} \mathrm{C}$ was a layer of dense crystallites approximately $1 \mathrm{~m}$ in diameter (Figure 8). These crystallites were determined to be very rich in $U$. However, because of the small size, even a good qualitative analysis could not be achieved. A diffuse U rich layer was also found in the $365 \mathrm{~d}$ leached specimens but the crystallites were not observed. This is a rather important finding since the gel layer was about $10 \mathrm{~m}$ thicker in the $728 \mathrm{~d}$ specimen. This would indicate that as the gel layer grew from $26 \mu m$ at $365 d$ to $35 \mu m$ at $728 d$, the $\mathrm{U}$ tended to migrate with and toward the glass/gel layer interface and the uranium concentrated enough to crystallize.

The rate of reaction of glass with water at $40^{\circ} \mathrm{C}$ after $728 \mathrm{~d}$ of leaching did not decrease with time, unlike results ohtained at $90^{\circ} \mathrm{C}$. In general, this appears to have been due to very slow leaching kinetics, and therefore, a slow approach to saturation of critical components in solution such as silica. Approach to saturation with respect to silica has been found to moderate the rate of glass reaction (Pederson, Buckwalter, McVay, and Riddle 1983). Solution data generally indicated a smooth rise in concentration of the soluble species, such as $\mathrm{B}, \mathrm{Na}$, and $\mathrm{Li}$, throughout the $728 \mathrm{~d}$ reaction period. Figure 5 shows that the $\mathrm{pH}$ rose rapidly to about 9.2 then fell to a final value of about 8.6. There appeared to be a slight halt in the uniform rise at about $182 \mathrm{~d}$. This maybe due to an error in the measurement of the $\mathrm{pH}$ for one of the specimens (Appendix A, Table Al, spec. 82П-287 and 288). This halt was followed by a nearly linear rise in the normalized mass loss of $\mathrm{B}, \mathrm{Li}$, and $\mathrm{Na}$, while the $\mathrm{pH}$ remained nearly constant. Solubility controls for elements such as $\mathrm{Fe}, \mathrm{Ca}, \mathrm{Cs}$, $\mathrm{Si}$, etc. were indicated by the solution analyses (Figures 1 and 2), although slow kinetics relative to matrix dissolution may also be an explanation.

At $90^{\circ} \mathrm{C}$ steady increases in the solution concentrations of the more soluble elements, such as B, Li, and $\mathrm{Na}$, were noted for the first $365 \mathrm{~d}$, followed by a leveling off in the rate of increase between $365 \mathrm{~d}$ and $728 \mathrm{~d}$ (Figure 3 ). The behavior of the other elements in solution indicated that new solid phases were controlling the concentrations or that the concentrations were a result of slow kinetics (Figures 5 and 6 ). The pH rose rapidly to 10.1 , then, over the remaining reaction time, decreased slightly to about 9.9 (Figure 6 ). 
Additional understanding of the reaction between the glass and deionized water can be obtained by calculating what the solution chemistry ought to have been based on uniform reaction of the glass with water followed by solubility controls for elements that form alteration products. The results of such a calculation for the $40^{\circ} \mathrm{C}$ data is shown in Figure 9. This plot was constructed using the PHREEOE geochemical code (Parkhurst, Thorstenson, and Plummer 1980). In this plot data for the ordinate were calculated by dividing the theoretical concentration of any given element by the mass fraction of that element in the glass. Data for the $x$-axis were calculated in a similar manner but are expressed as the amount of glass dissolved in solution with the assumption that all of the glass that reacts dissolves. This quantity gives a parameter which is equivalent to the reaction progress parameter discussed by Aagaard and Helgeson (1982) and applied to glass dissolution by Grambow (1983a). Any element for which solubility controls do not exist at the concentrations of interest here, such as boron, are calculated to leach congruently and the data for both axes are equal. In these plots the curves represent the calculated data and the data points come from the experiments. For this plot (Figure 9) the solid alteration phases that best fit the data were $\mathrm{Fe}(\mathrm{OH})_{3}$, $\mathrm{Nd}(\mathrm{OH})_{3}$, rhodochrosite $\left(\mathrm{MnCO}_{3}\right)$, analcime $\left(\mathrm{NaAlSi}_{2} \mathrm{O}_{6} \cdot \mathrm{H}_{2} \mathrm{O}\right)$, sepiolite $\left.\mathrm{CMg}_{2} \mathrm{Si}_{3} \mathrm{O}_{6}(\mathrm{OH})_{4}\right]$, calcite $\left(\mathrm{CaCO}_{3}\right)$, and amorphous $\mathrm{SiO}_{2}$. It should be noted that these phases were used because they best fit the solution data, but no experimental evidence for these phases could be found. Rhodochrosite does not appear to be a good solid to have been used for Mn since the leach data, except for one data point, appear to be undersaturated with respect to this solid. However, other Mn containing minerals were not available in the version of PHREEQE that was used for the calculations. No Mn solids were identified by the MCC (1984) for specimens leached at $70^{\circ} \mathrm{C}$. The $\mathrm{Ca}$ data are also undersaturated with respect to calcite, but it has been suggested that this is due to sorption and not to a solubility control (Strachan, Krupka, and Grambow 1984). Leonhardite $\left.\mathrm{Ca}_{2} \mathrm{Al}_{4} \mathrm{Si}_{8} \mathrm{O}_{24} 7_{2} \mathrm{H}_{2}\right]$ was also used as a control for $\mathrm{Ca}$ in one of the calculations, but the calculated Ca data were more than two orders of magnitude below the observed values. Aluminum appears to be controlled by analcime. This phase has frequently been 


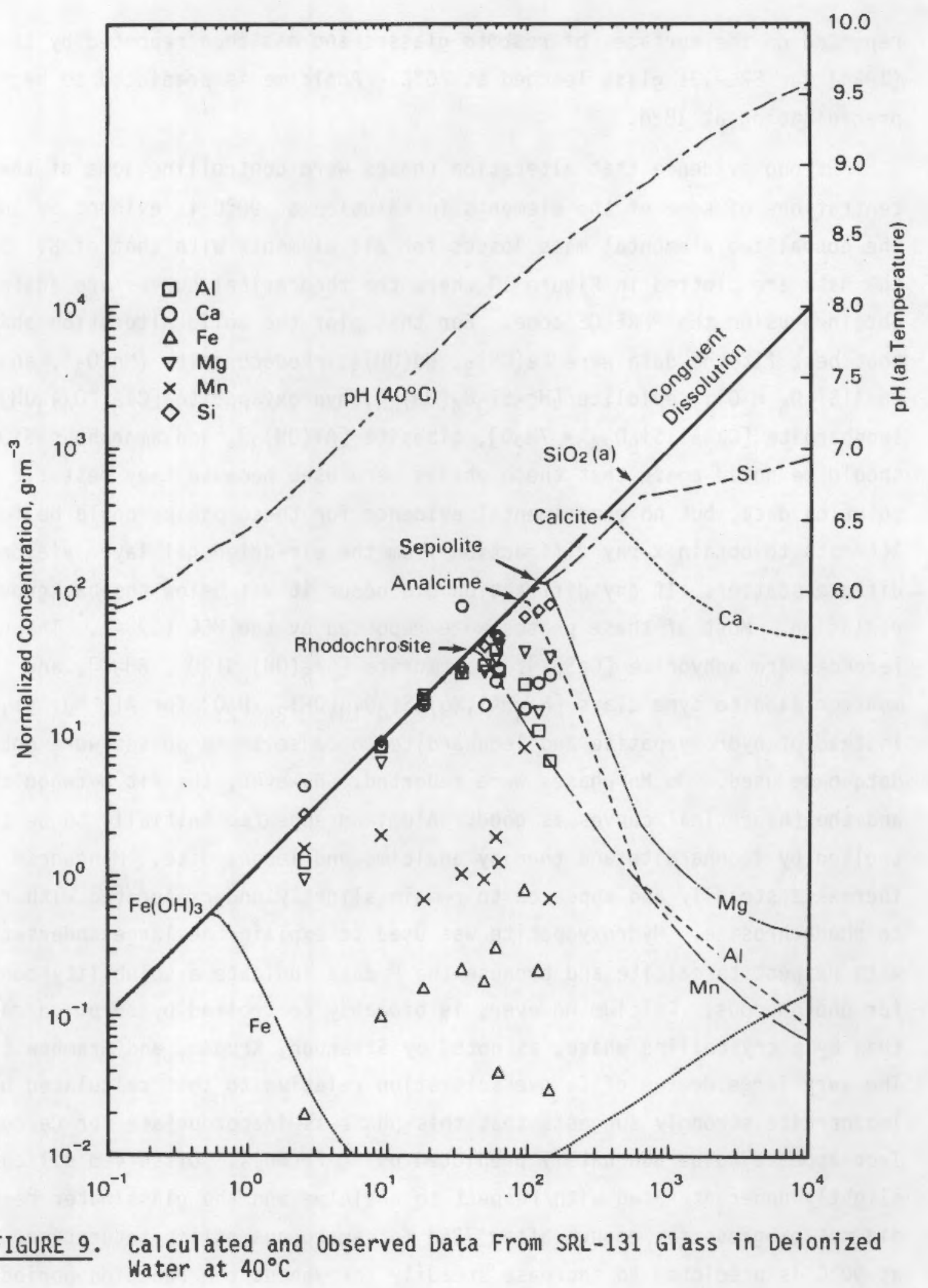


reported on the surfaces of reacted glasses and has been reported by the MCC (1984) for SRL-131 glass leached at $70^{\circ} \mathrm{C}$. Analcime is predicted to begin precipitating at $182 \mathrm{~d}$.

Strong evidence that alteration phases were controlling some of the concentrations of some of the elements in solution at $90^{\circ} \mathrm{C}$ is evident by comparing the normalized elemental mass losses for all elements with that of $B$. Some of the data are plotted in Figure 10 where the theoretical curves are again obtained using the PHREEQE code. For this plot the solid alteration phases that best fit the data were $\mathrm{Fe}(\mathrm{OH})_{3}, \mathrm{Nd}(\mathrm{OH})_{3}$, rhodochrosite $\left(\mathrm{MnCO}_{3}\right)$, analcime ( $\left.\mathrm{NaAlSi}{ }_{2} \mathrm{O}_{6} \mathrm{H}_{2} \mathrm{O}\right)$, sepiolite $\left[\mathrm{Mg}_{2} \mathrm{Si}_{3} \mathrm{O}_{6}(\mathrm{OH})_{4}\right]$, hydroxyapatite $\left[\mathrm{Ca}_{5}\left(\mathrm{PO}_{4}\right)_{3} \mathrm{OH}\right]$, leonhardite $\left[\mathrm{Ca}_{2} \mathrm{Al}_{4} \mathrm{Si}_{8} \mathrm{O}_{24} \cdot \mathrm{7H}_{2} \mathrm{O}\right]$, gibbsite $\left[\mathrm{Al}(\mathrm{OH})_{3}\right]$, and amorphous $\mathrm{SiO}_{2}$. It should be noted again that these phases were used because they best fit the solution data, but no experimental evidence for these phases could be found. Attempts to obtain $x$-ray diffraction from the air-dried gel layer yielded only diffuse scatter. If any diffraction did occur it was below the background radiation. Most of these phases were reported by the MCC (1984). The differences are anhydrite $\left[\mathrm{CaSO}_{4}\right]$, tobermorite $\left[\mathrm{Ca}_{5}(\mathrm{OH})_{2} \mathrm{Si}_{6}{ }^{0}{ }_{16} 8 \mathrm{H}_{2} \mathrm{O}\right]$, and montmorillonite type clays $\left[\mathrm{Na}_{n}(\mathrm{Al}, \mathrm{Mg})_{2} \mathrm{Si}_{4} \mathrm{O}_{10}(\mathrm{OH})_{2} \times \mathrm{H}_{2} \mathrm{O}\right]$ for $\mathrm{Al}, \mathrm{Mg}$, Si, and $\mathrm{Ca}$ instead of hydroxyapatite and leonhardite, because these phases were not in the data base used. No Mn phases were reported. However, the fit between the data and the theoretical curves is good. Aluminum appeared initially to be controlled by leonhardite and then by analcime and leonhardite. Manganese increased steadily and appeared to remain slightly undersaturated with respect to rhodochrosite. Hydroxyapatite was used to explain the large undersaturation with respect to calcite and because the $P$ data indicate a solubility control for phosphorous. Calcium however, is probably controlled by sorption rather than by a crystalline phase, as noted by Strachan, Krupka, and Grambow (1984). The very large degree of Ca oversaturation relative to that calculated using leonhardite strongly suggests that this phase is inappropriate for Ca control. Iron appears to be adequately predicted using $\mathrm{Fe}(\mathrm{OH})_{3}$. Dissolved silica was slightly undersaturated with respect to analcime and the glass/water reaction did not progress far enough after $728 \mathrm{~d}$ for amorphous silica saturation. The $\mathrm{pH}$ at $90^{\circ} \mathrm{C}$ is predicted to increase steadily throughout the reaction period, but the $\mathrm{pH}$ values at $25^{\circ} \mathrm{C}$ were not calculated. 


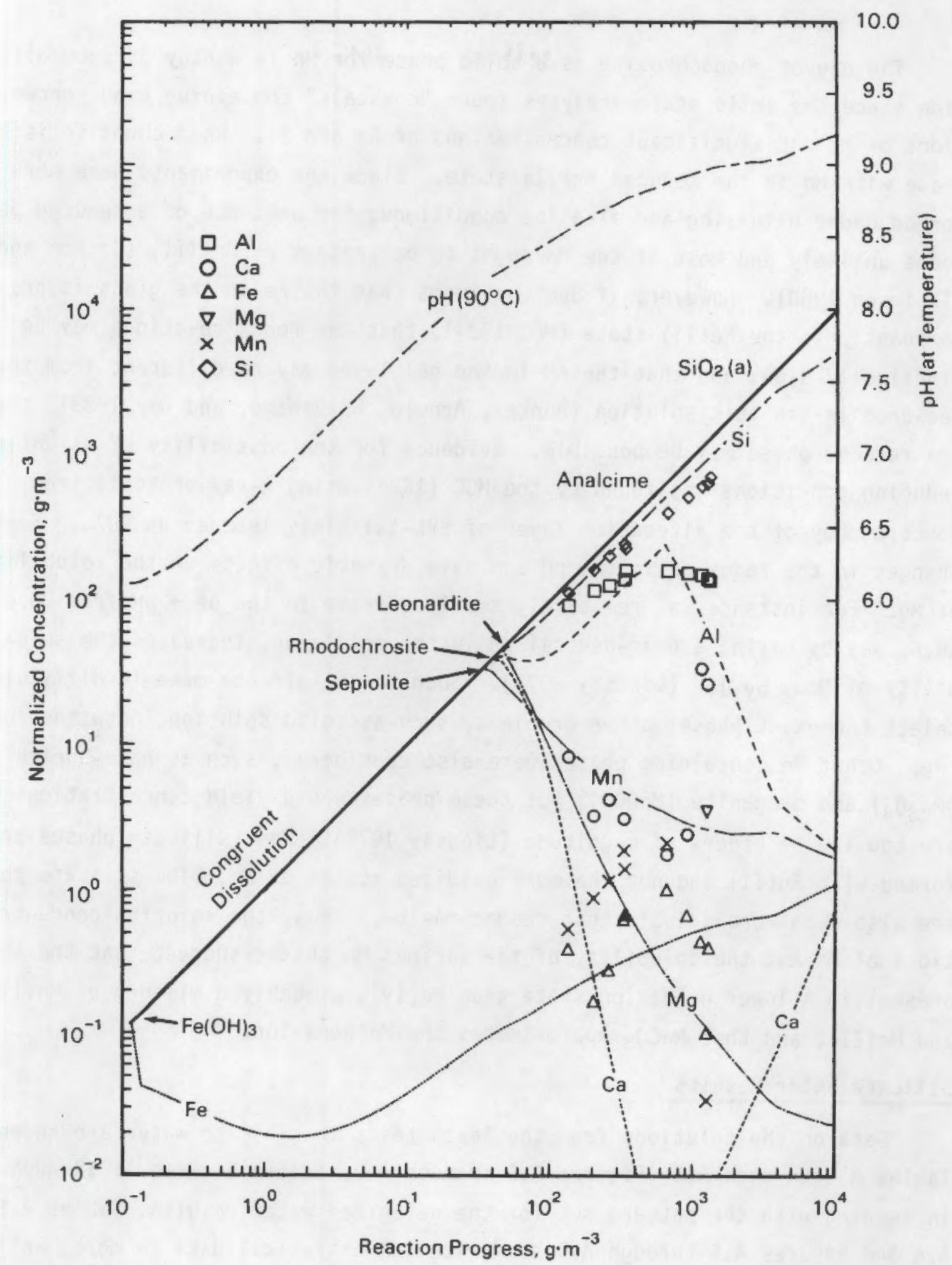

FIGURE 10. Calculated and Observed Data From SRL-131 Glass in Deionized Water at $90^{\circ} \mathrm{C}$ 
The use of rhodochrosite as a solid phase for Mn is worthy of some discussion since the solid state analyses found "crystals" containing high concentrations of Mn and significant concentrations of Fe and Si. Rhodochrosite is a phase with $\mathrm{Mn}$ in the reduced $\mathrm{Mn}$ (II) state. Since the experiments were performed under oxidizing and alkaline conditions, the presence of a reduced phase seems unlikely and most of the Mn ought to be present as $\mathrm{Mn}$ (III) (Cotton and Wilkinson 1980). However, if one considers that the $\mathrm{Fe}$ in the glass is predominantly in the $\mathrm{Fe}$ (II) state (MCC 1984), that the redox reactions may be kinetically slow, and that the $\mathrm{pH}$ in the gel layer may be different from that measured in the bulk solution (Bunker, Arnold, Beauchamp, and Day 1983), then the reduced phase may be possible. Evidence for the possibility of slightly reducing conditions was found by the MCC (1984) using $x$-ray photoelectron spectroscopy of the alteration layer of SRL-131 glass leached at $90^{\circ} \mathrm{C}$. Small changes in the redox or in the $\mathrm{pH}$ can have dramatic effects on the solubility of $\mathrm{Mn}$. For instance, a relatively small decrease in the pe $+\mathrm{pH}$ from 20.6 to 16.6, say by having a near-neutral pH in the gel layer, increases the solubility of $\mathrm{MnO}_{2}$ by $10^{8}$ (Lindsay 1979). Such strong effects make it difficult to select the exact phase; other problems, such as solid solution, notwithstanding. Other Mn containing phases were also considered, such as hausmannite $\left(\mathrm{Mn}_{3} \mathrm{O}_{4}\right)$ and manganite $(\mathrm{MnOOH})$, but these phases would yield concentrations that are too low by orders of magnitude (Lindsay 1979). Most silicate phases are formed with $\mathrm{Mn}$ (II) and not the more oxidized states of Mn. The silicate phases are also much more soluble than rhodochrosite. Thus, the solution concentrations of $M n$ and the solubility of the various Mn phases suggest that the Mn was present in a lower oxidation state than $M n$ (IV), probably a mixture of $M n$ (III) and $\mathrm{Mn}(\mathrm{II})$, and that $\mathrm{MnCO}_{3}$ approximates the $\mathrm{Mn}$ behavior.

\section{Silicate Water Results}

Data on the solutions from the leach tests in silicate water are shown in Tables A.5 through A.8, Figures A.5 through A.9, and in Figures 11 through 15. In keeping with the pattern set for the deionized water results, Tables $A .5$ and A.6 and Figures A.5 through A.9 summarize the analytical data in $\mathrm{mg} / \mathrm{L}$, while Tables $A .7$ and $A .8$ and Figures 11 through 13 summarize the normalized elemental mass losses. Tables A.5 and A.7, Figures A.5 through A.9, and Figures 11, 12, 


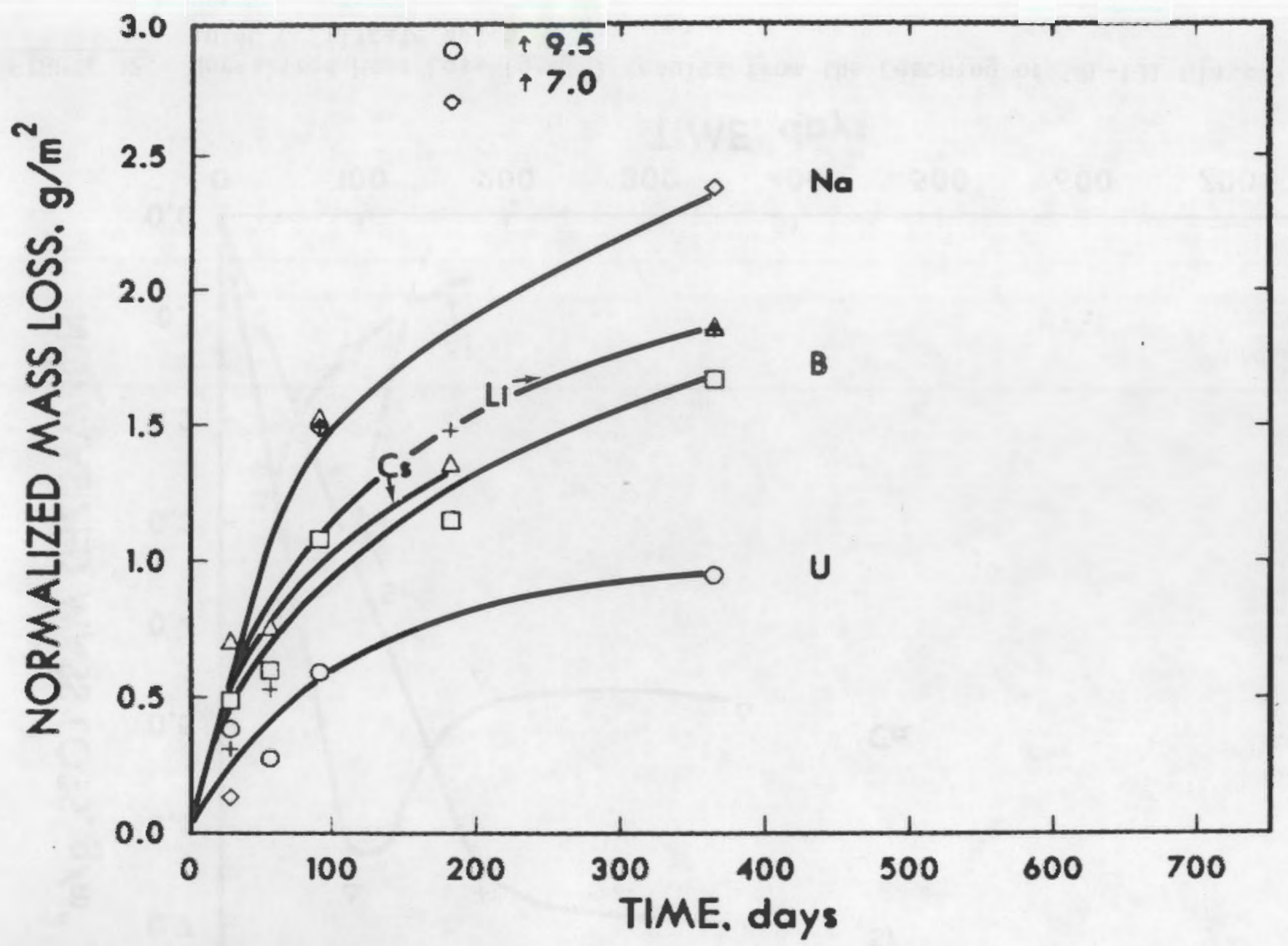

FIGURE 11. Normalized Mass Loss $\left(\mathrm{g} \cdot \mathrm{m}^{-3}\right)$ Results from the Leaching of SRL-131 Glass in $40^{\circ} \mathrm{C}$ Silicate Water 


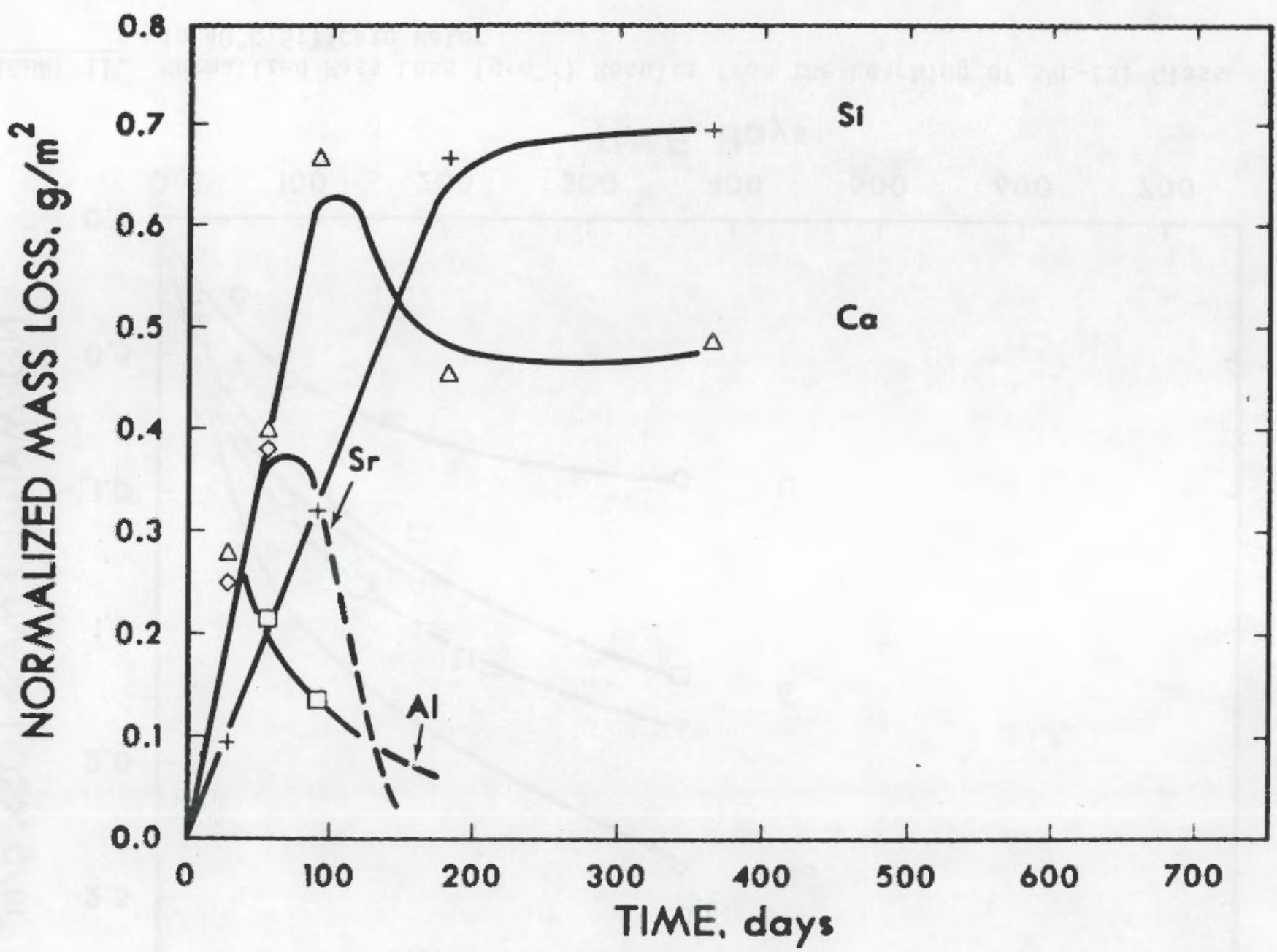

FIGURE 12. Normalized Mass Loss $\left(\mathrm{g} \cdot \mathrm{m}^{-3}\right)$ Results from the Leaching of SRL-131 Glass in $40^{\circ} \mathrm{C}$ Silicate Water 


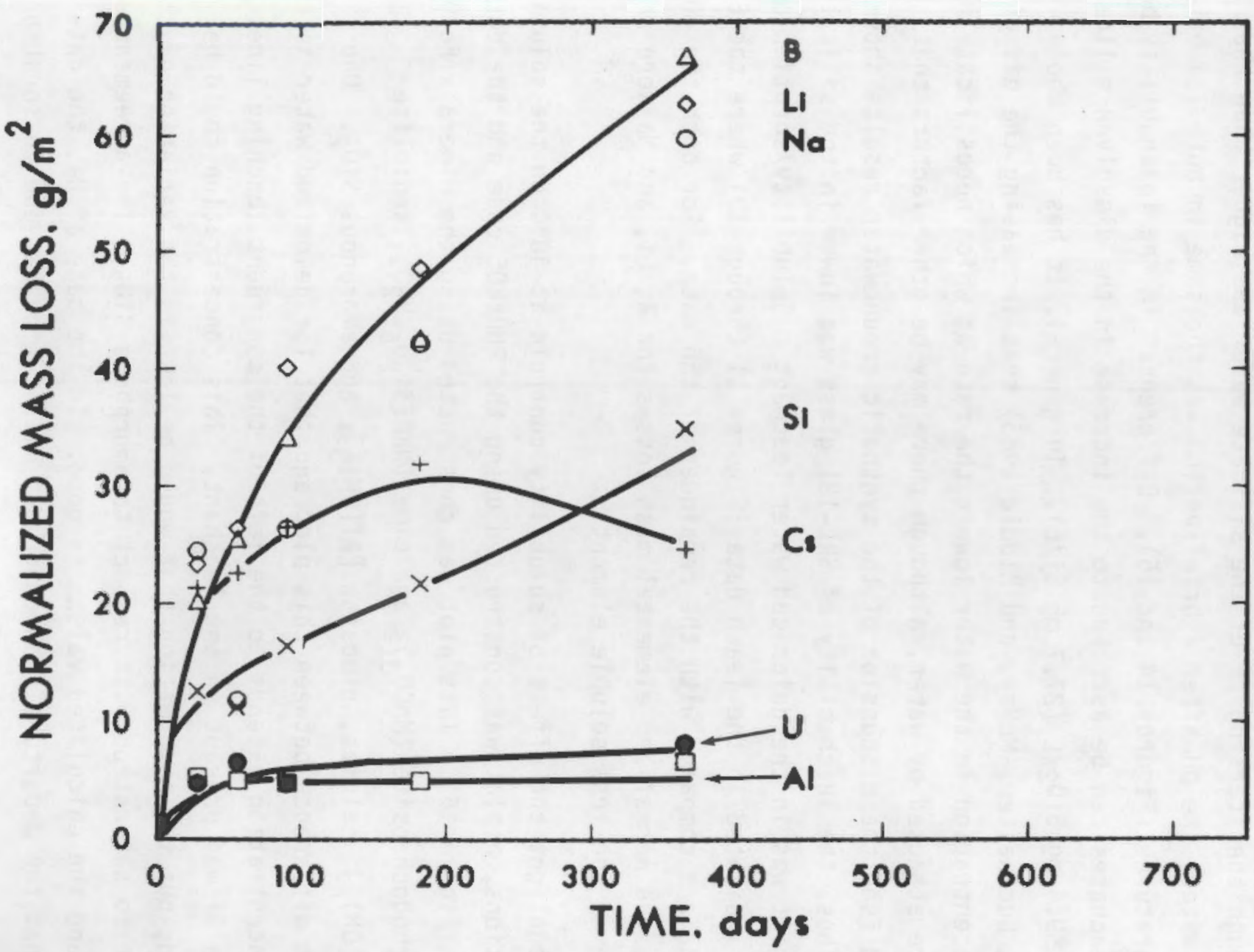

FIGURE 13. Normalized Mass LosS $\left(\mathrm{g} \cdot \mathrm{m}^{-3}\right)$ Results from the Leaching of SRL-131 Glass in $90^{\circ} \mathrm{C}$ silicate Water 
and 14 are for the $40^{\circ} \mathrm{C}$ data while the remainder are for the $90^{\circ} \mathrm{C}$ data. The $\mathrm{pH}$ data are summarized in Figures 14 and 15 . In both cases the experiments were only carried out for $365 \mathrm{~d}$.

Although the starting $\mathrm{pH}$ of the silicate water was higher than that of the deionized water, the $\mathrm{pH}$ after a brief period was the same in both leachates at both temperatures (Figures 14 and 15). Differences in the leachability between the two leachates can be ascribed to the increase in the dissolved silica, which was $59.4 \mathrm{mg} \mathrm{SiO} / \mathrm{L}(27.7 \mathrm{mg} \mathrm{Si} / \mathrm{L})$. In general, it has been shown (Pederson, Buckwalter, McVay, and Riddle 1983) that increasing the dissolved silica concentration in the water lowers the rate at which borosilicate waste glasses are attacked by water, although there may be other factors that change this trend (see the discussion of the synthetic groundwater results shown below). Thus, the leachability of SRL-131 glass was lower in the silicate water than it was in the deionized water leachant. Solubility/sorption controls are indicated in the leach data (Figures 11 through 13) where the B, Li, and $\mathrm{Na}$ data are compared with the remainder of the data. For both the 40 and $90^{\circ} \mathrm{C}$ data, the normalized elemental mass losses for $\mathrm{B}, \mathrm{Li}$, and $\mathrm{Na}$ were greater than those of the less soluble elements.

To highlight the effect of solubility controls at $40^{\circ} \mathrm{C}$ on the solution concentrations, a plot was constructed using the PHREEQE code and the data from Table A.6 (Figure 16). This plot was constructed using the minerals $\mathrm{Fe}(\mathrm{OH})_{3}$, $\mathrm{Nd}(\mathrm{OH})_{3}$, rhodochrosite $\left(\mathrm{MnCO}_{3}\right)$, analcime $\left(\mathrm{NaAlSi}_{2} \mathrm{O}_{6} \cdot \mathrm{H}_{2} \mathrm{O}\right)$, sepiolite $\left[\mathrm{Mg}_{2} \mathrm{Si}_{3} \mathrm{O}_{6}(\mathrm{OH})_{4}\right]$, calcite, gibbsite $\left[\mathrm{Al}(\mathrm{OH})_{3}\right]$, and amorphous $\mathrm{SiO}_{2}$. One noticeable difference between this plot and that for deionized water is that the Si concentration extends to the left of the congruent leaching line. This is because $\mathrm{Si}$ was present in the leachant. This concentration could be subtracted, but the information that would be lost is the variation of the Si just prior to saturation with respect to amorphous $\mathrm{SiO}_{2}$. The agreement between the data and the calculated values is good. In the case of $\mathrm{Ca}$, the data suggest that the departure from congruent dissolution was due to sorption, as discussed above for the deionized water leachant. There is good agreement between the calculated and observed Mg concentrations based on sepiolite. In general, there did not appear to have been any solubility controls for $\mathrm{Mg}$ in 


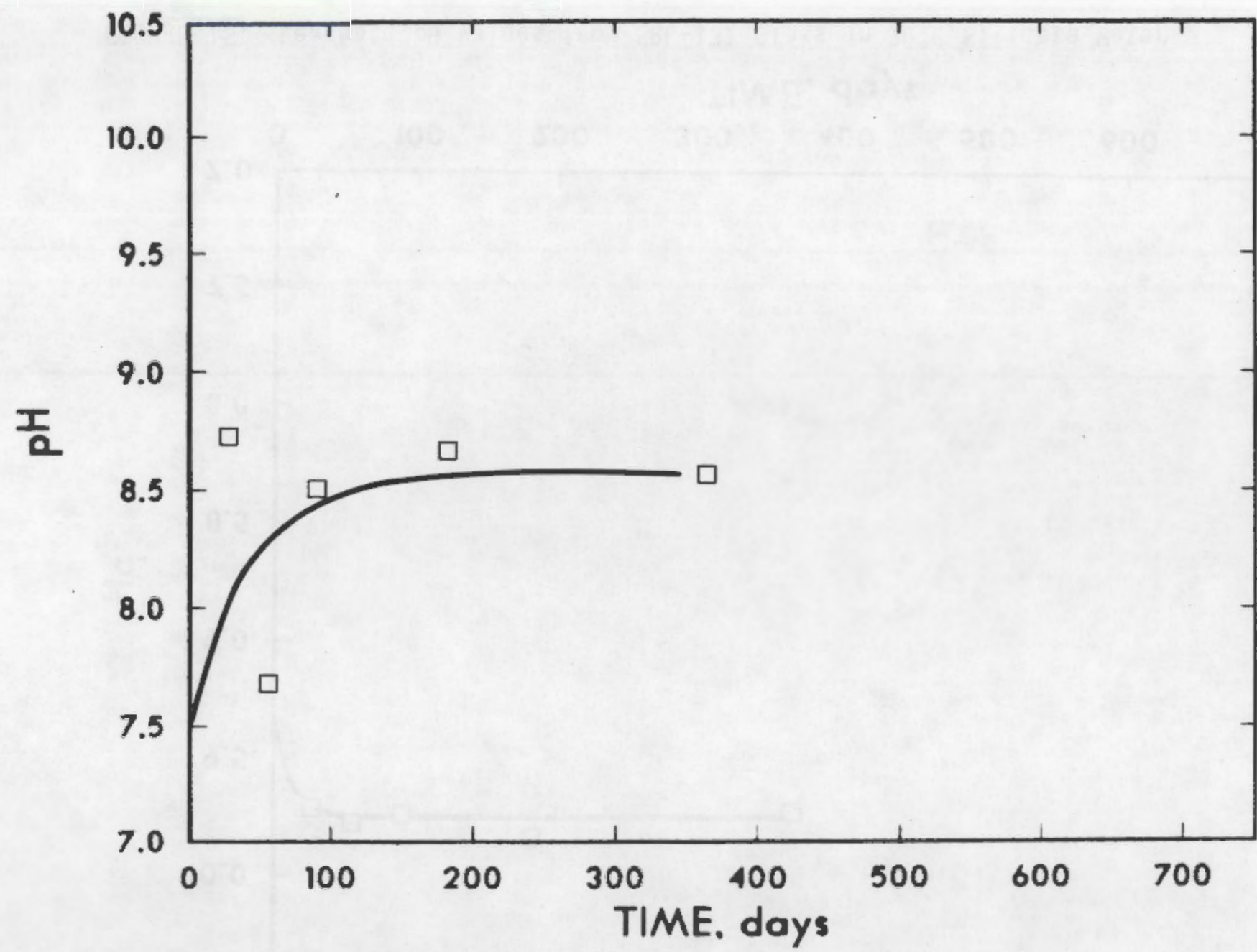

FIGURE 14. Leachate $\mathrm{pH}$ values from SRL-131 Glass in $40^{\circ} \mathrm{C}$ silicate Water 


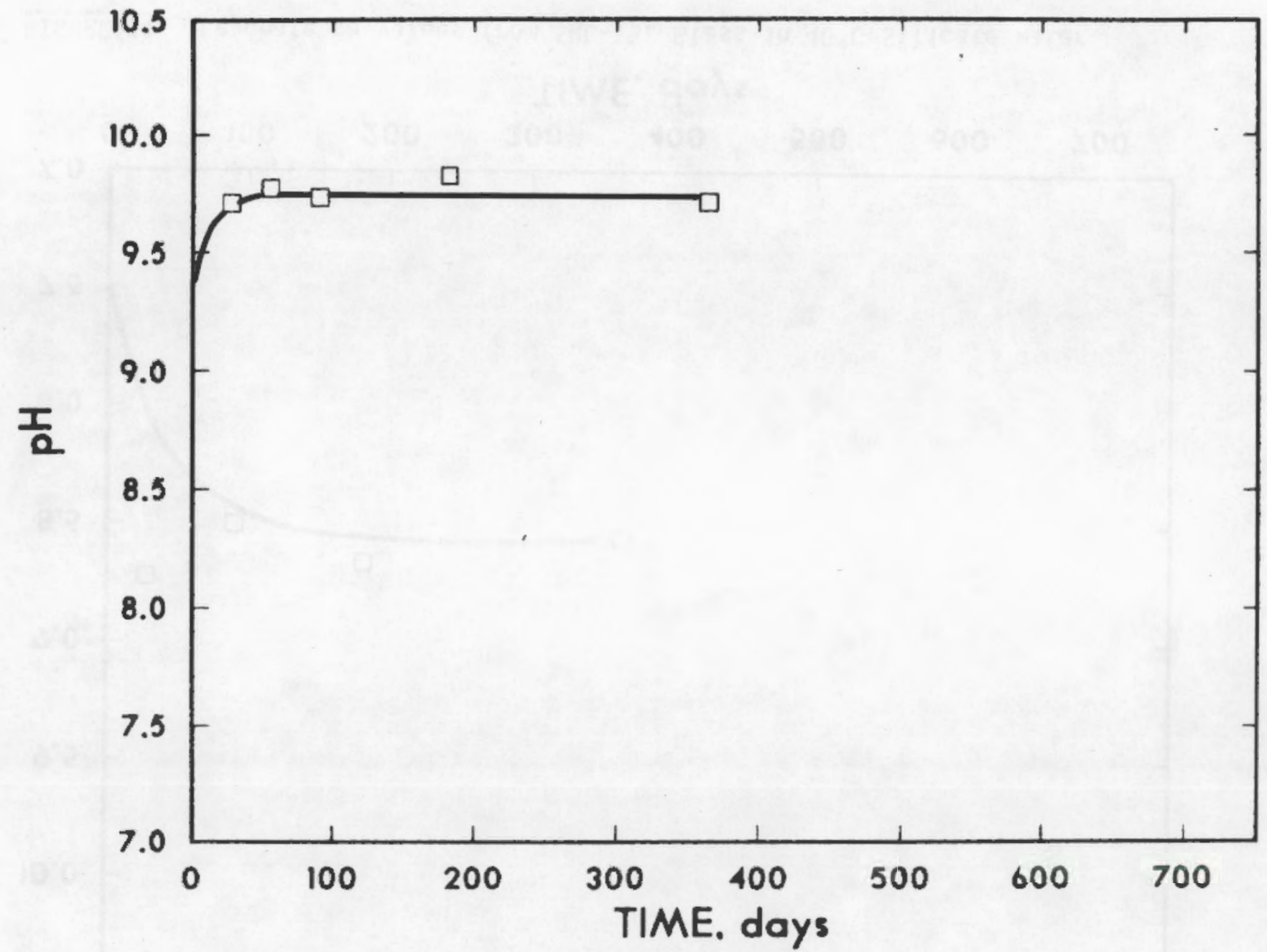

FIGURE 15. Leachate $\mathrm{pH}$ values from SRL-131 Glass in $90^{\circ} \mathrm{C}$ silicate water 


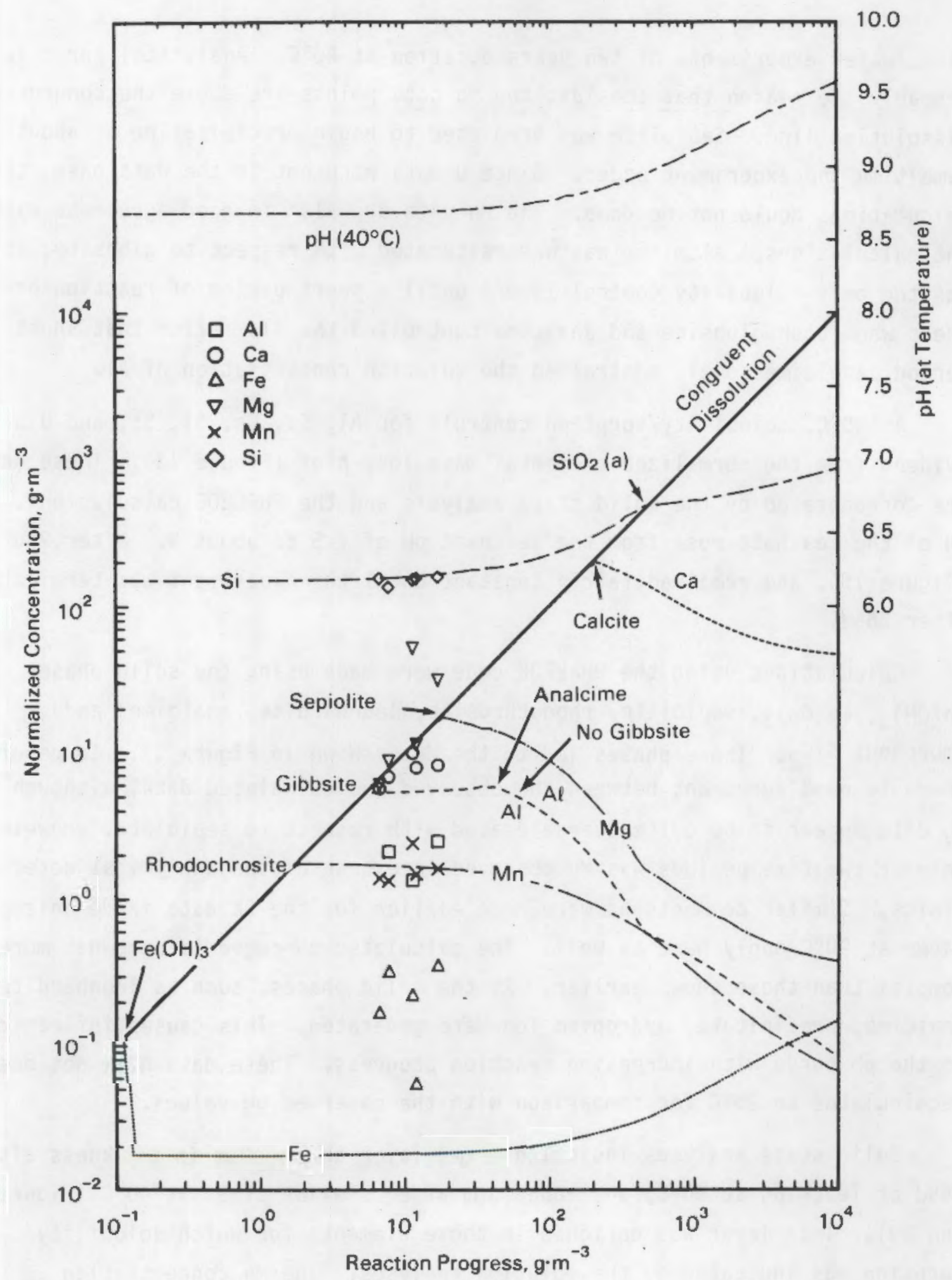

FIGURE 16. Calculated and Observed Data From SRL-131 Glass in Silicate Water at $40^{\circ} \mathrm{C}$ 
glass/water experiments of two years duration at $40^{\circ} \mathrm{C}$. Analytical error is probably the reason that the last two Mg data points are above the congruent dissolution line. Sepiolite was predicted to begin precipitating at about the same time the experiment ended. Since $U$ data were not in the data base, these calculations could not be done. The Mn data are also in good agreement with the calculations. Aluminum was undersaturated with respect to gibbsite, which was the only solubility control for $A 1$ until a short period of reaction progress when both gibbsite and analcime controlled the Al. After that short period, analcime solely controlled the solution concentration of $\mathrm{Al}$.

At $90^{\circ} \mathrm{C}$, solubility/sorption controls for $\mathrm{Al}, \mathrm{Ca}, \mathrm{Cs}, \mathrm{Si}, \mathrm{Sr}$, and $\mathrm{U}$ are evident from the normalized elemental mass loss plot (Figure 13). These data are corroborated by the solid state analysis and the PHREEQE calculations. The $\mathrm{pH}$ of the leachate rose from the leachant $\mathrm{pH}$ of 7.5 to about 9.7 after $28 \mathrm{~d}$ (Figure 15), and remained fairly constant until the experiment was terminated after 365 .

Calculations using the PHREEQE code were made using the solid phases $\mathrm{Nd}(\mathrm{OH})_{3}, \mathrm{Fe}(\mathrm{OH})_{3}$, sepiolite, rhodochrosite, leonhardite, analcime, and amorphous $\mathrm{SiO}_{2}$. These phases led to the data shown in Figure 17. In general, there is good agreement between the observed and calculated data, although the Mg data appear to be quite oversaturated with respect to sepiolite. However, only at two time periods was Mg observed in excess of the analytical detection limits. Similar comments as were made earlier for the Ca data in deionized water at $90^{\circ} \mathrm{C}$ apply here as well. The calculated $\mathrm{pH}$ curve is somewhat more complex than those shown earlier. As the solid phases, such as leonhardite and analcime, precipitate, hydronium ions are generated. This causes inflections in the $\mathrm{pH}$ curve with increasing reaction progress. These data have not been recalculated to $25^{\circ} \mathrm{C}$ for comparison with the observed $\mathrm{pH}$ values.

Solid state analyses indicated a gel layer about $10 \mathrm{~m}$ in thickness after $365 \mathrm{~d}$ of leaching at $90^{\circ} \mathrm{C}$, and about $3 \mathrm{~m}$ after similar times at $40^{\circ} \mathrm{C}$ (Figures 18 and 19). This layer was enriched in those elements for which solubility/ sorption was indicated by the solution analyses. The Mn concentration increased between the gel/glass interface while the $\mathrm{Ca}$ and $\mathrm{U}$ concentrations reached maxima within the gel layer then decreased toward the surface. In the 


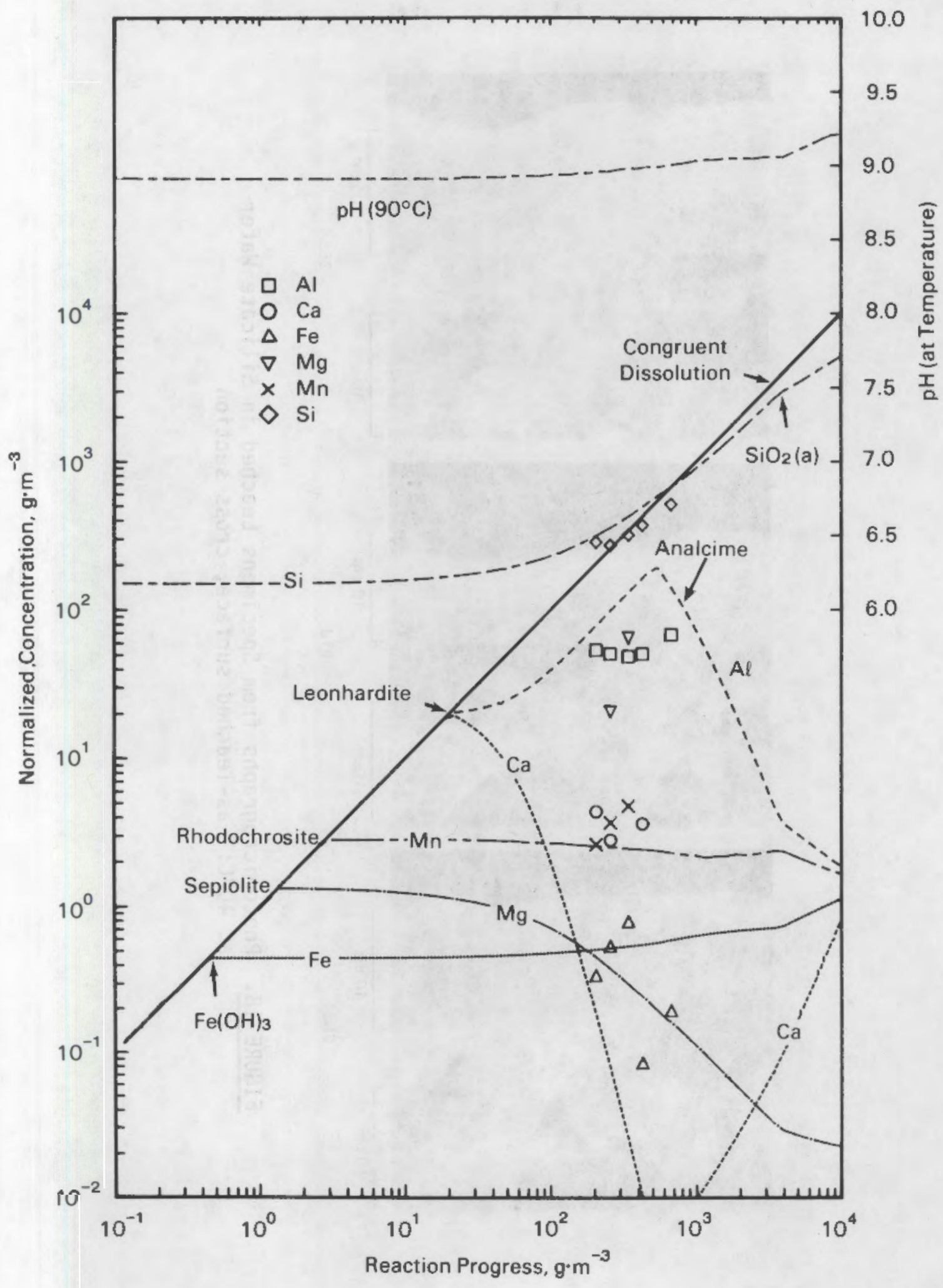

FIGURE 17. Calculated and Observed Data From SRL-131 Glass in Silicate Water at $90^{\circ} \mathrm{C}$ 


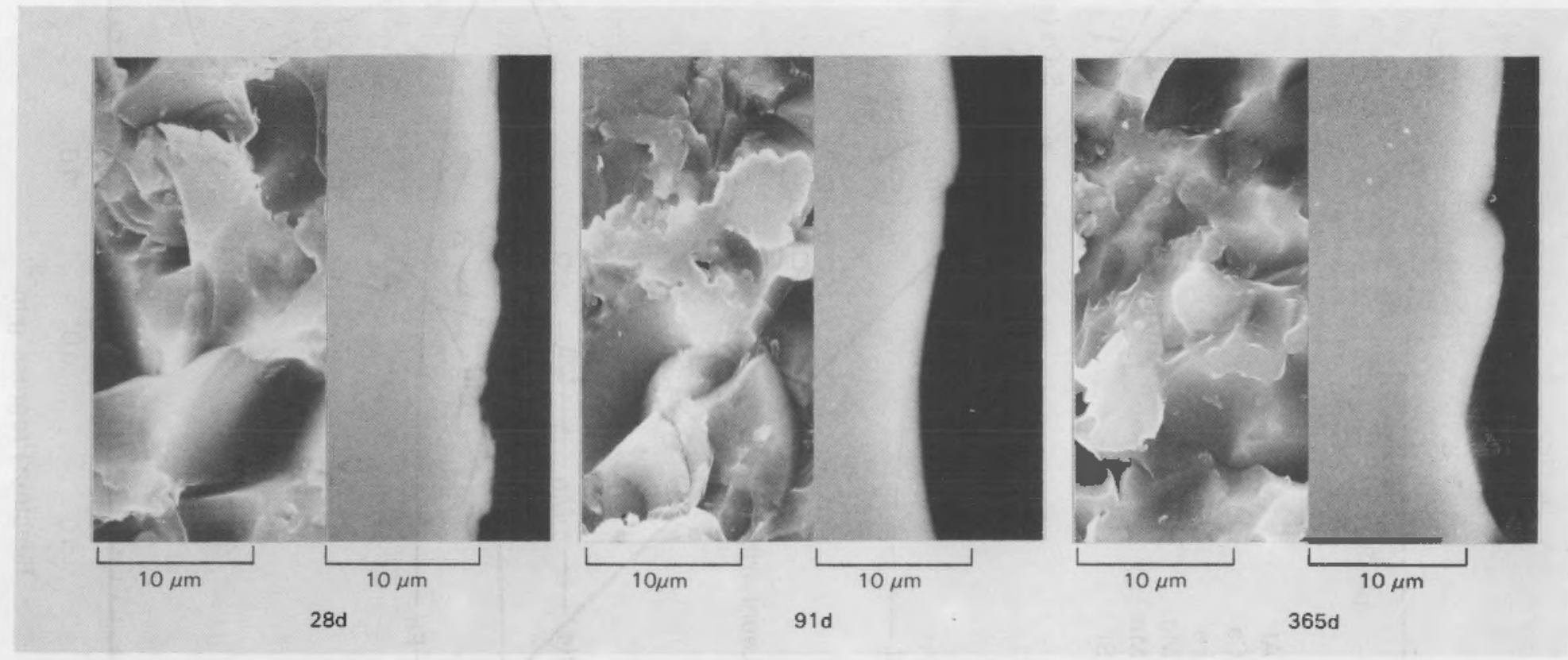

FIGURE 18. Photomicrographs from Specimens Leached in Silicate Water at $40^{\circ} \mathrm{C}$ : as-leached surface, cross section 


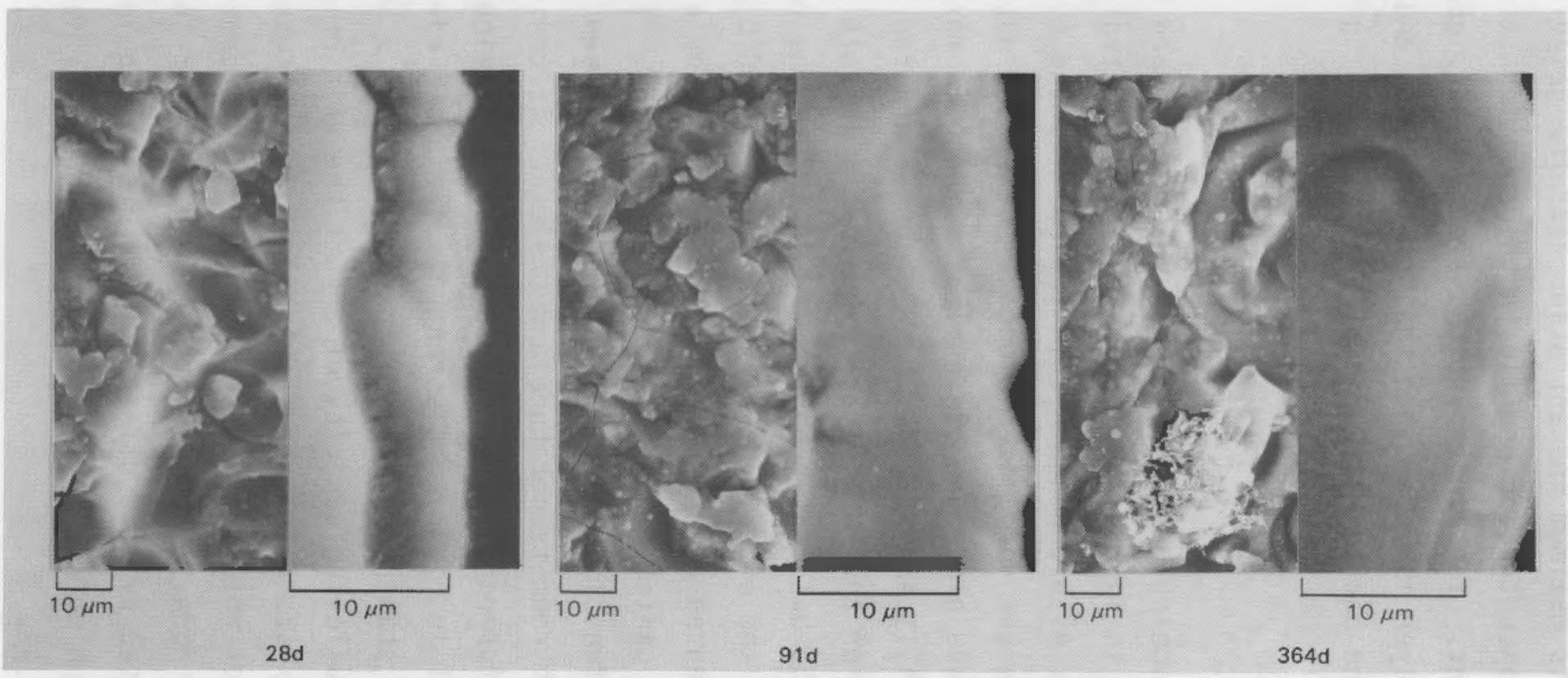

FIGURE 19. Photomicrographs from Specimens Leached in Silicate Water at $90^{\circ} \mathrm{C}$ : as-leached surface, cross section 
case of $\mathrm{Ca}$, the concentration reached a maximum near the middle of the gel layer. Uranium was at its maximum concentration near the gel/glass interface, similar to the uranium concentration profile on the specimens from the deionized water experiment. These observations are, however, qualitative since the density of the gel layer is lower than that of the glass and, in general, not known. Therefore, one has to be cautious when interpreting the solid state analyses in gel layers.

Salt Brine Results

Results from the leaching of SRL-131 glass in the standard MCC salt brine (MCC 1981) are tabulated in Tables A.g through A.12 and plotted in Figures 20 through 24 and in Figures A.10 through A.13. Tables A.11 and A.12 and Figures 20 through 22 are the normalized elemental mass loss data, while the remainder of the tables and plots are the analytical data in $\mathrm{mg} / \mathrm{L}$ or are $\mathrm{pH}$ values. Tables $\mathrm{A} .9$ and $\mathrm{A} .11$ and Figures 20,21 , and 23 are for the $40^{\circ} \mathrm{C}$ data while the remainder are for the $90^{\circ} \mathrm{C}$ data. Experiments in salt brine at $90^{\circ} \mathrm{C}$ were terminated after $365 \mathrm{~d}$ but continued to $728 \mathrm{~d}$ at $40^{\circ} \mathrm{C}$. The rationale behind the decision to continue the experiment at $40^{\circ} \mathrm{C}$ but not at $90^{\circ} \mathrm{C}$ was that the lower temperature represented a more realistic temperature for a salt repository after breach of the canister plus overpack (ONWI, 1983). Figures 23 and 24 show the $\mathrm{pH}$ as a function of time. Two curves are drawn in each figure; one is the $\mathrm{pH}$ measured at room temperature and the other is the corrected $\mathrm{pH}$. A Gran titration was performed to determine the $\mathrm{pH}$ error arising from the liquid junction potential in high ionic strength solutions (Pederson 1985). In this method, a series of standard acid additions are made to a known volume of salt brine, beyond the buffering capacity of any of the salt brine components. Where buffering is non-existant, a linear relation exists between the quantity of acid added per liter of solution and the hydrogen ion concentration, as measured using a pH electrode. The logarithm of the slope of that line gives the error in $\mathrm{pH}$ contributed by some of fset voltage at the liquid junction. For the MCC salt brine, the $\mathrm{pH}$ correction is $+0.98 \pm 0.01 \mathrm{pH}$ units, i.e. a measured $\mathrm{pH}$ of 7.00 is actually 7.98 .

From Figures 20 and 22, it is immediately obvious that the leachability of SRL-131 glass in the MCC salt brine is very low; lower, in fact, than in any of 


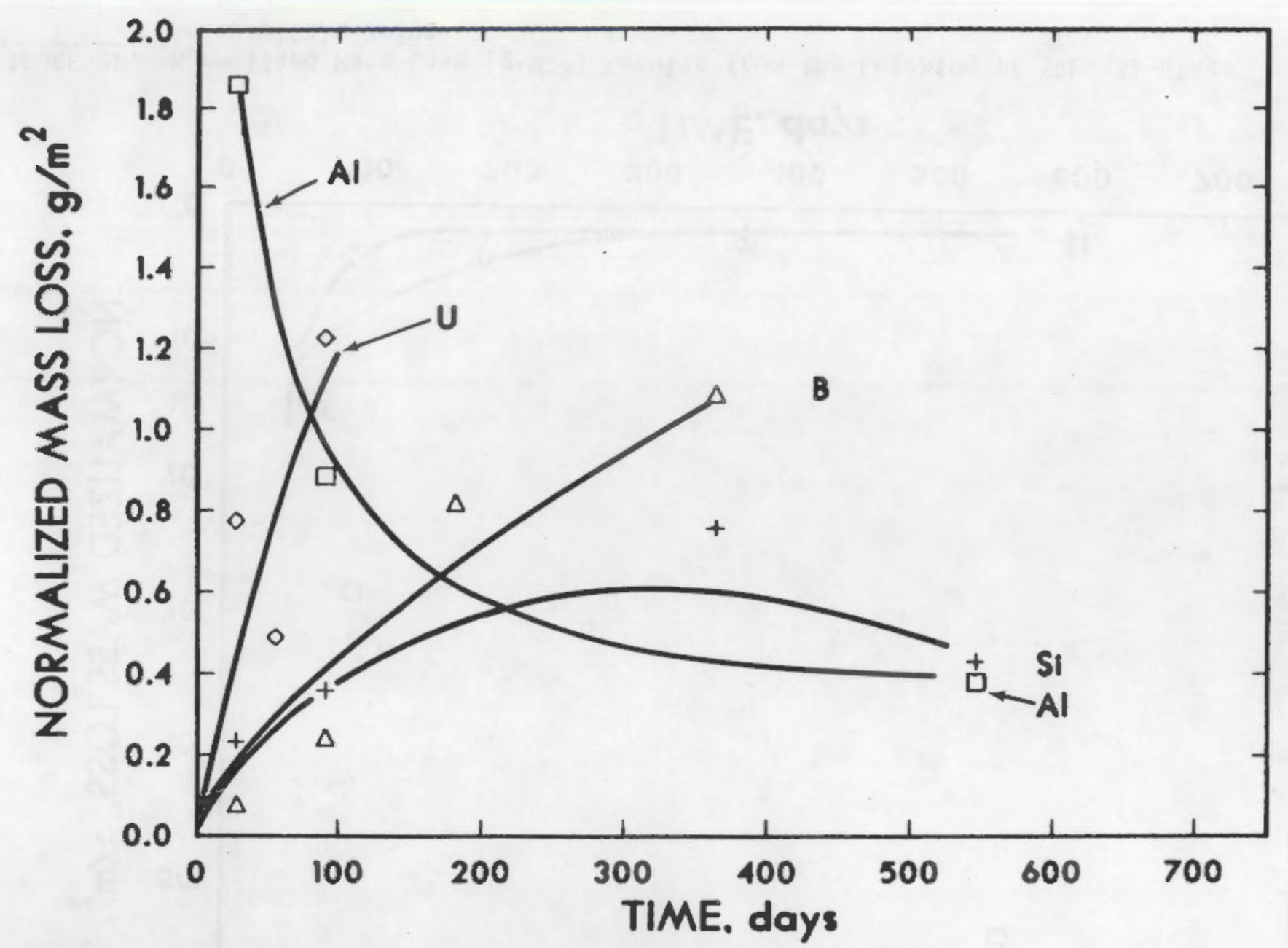

FIGURE 20. Normalized Mass Loss $\left(\mathrm{g} \cdot \mathrm{m}^{-3}\right)$ Results from the Leaching of SRL-131 Glass in $40^{\circ} \mathrm{C}$ Salt Brine 


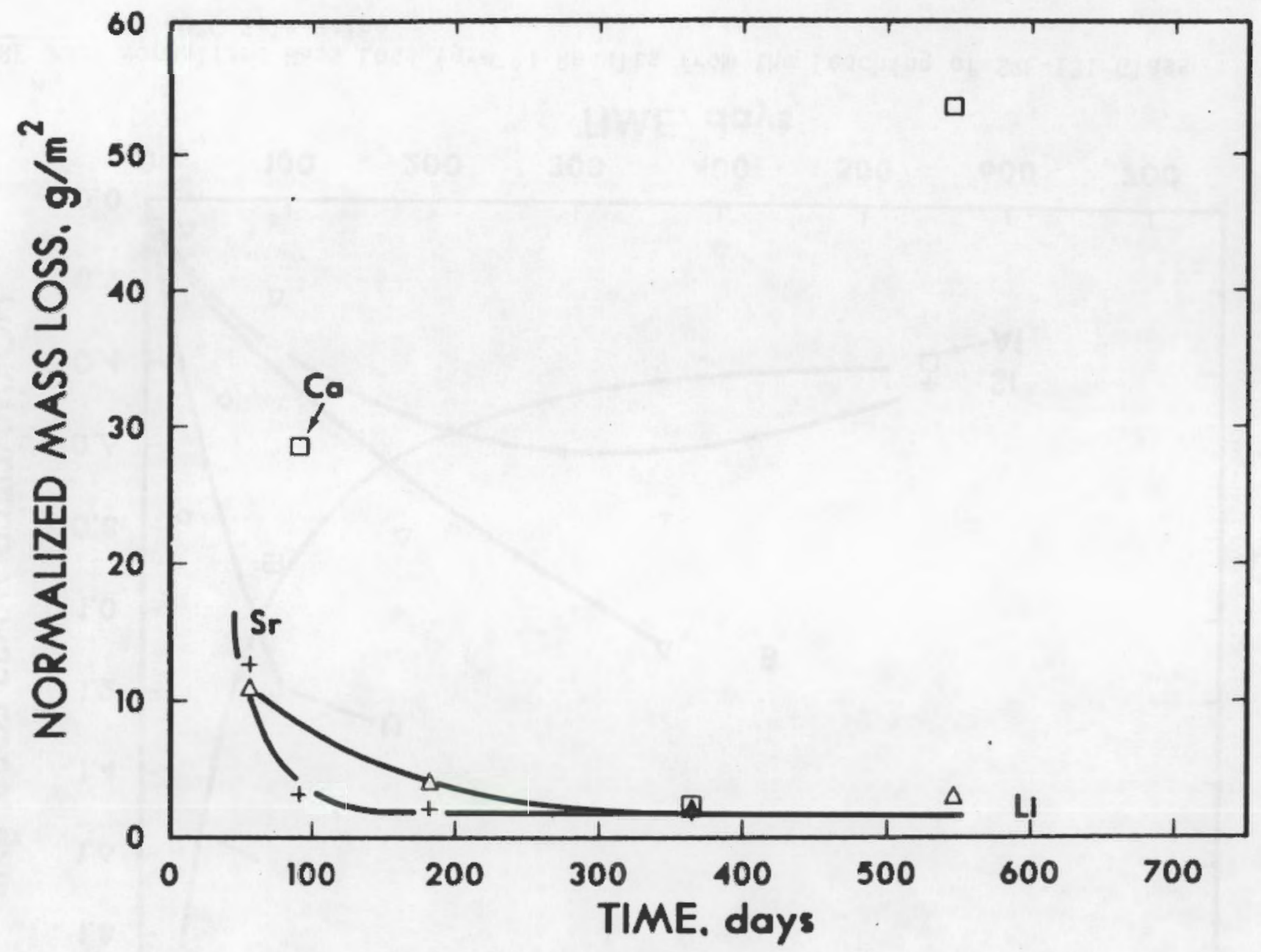

FIGURE 21. Normalized Mass Loss $\left(\mathrm{g} \cdot \mathrm{m}^{-3}\right)$ Results from the Leaching of SRL-131 Glass in $40^{\circ} \mathrm{C}$ Salt Brine 


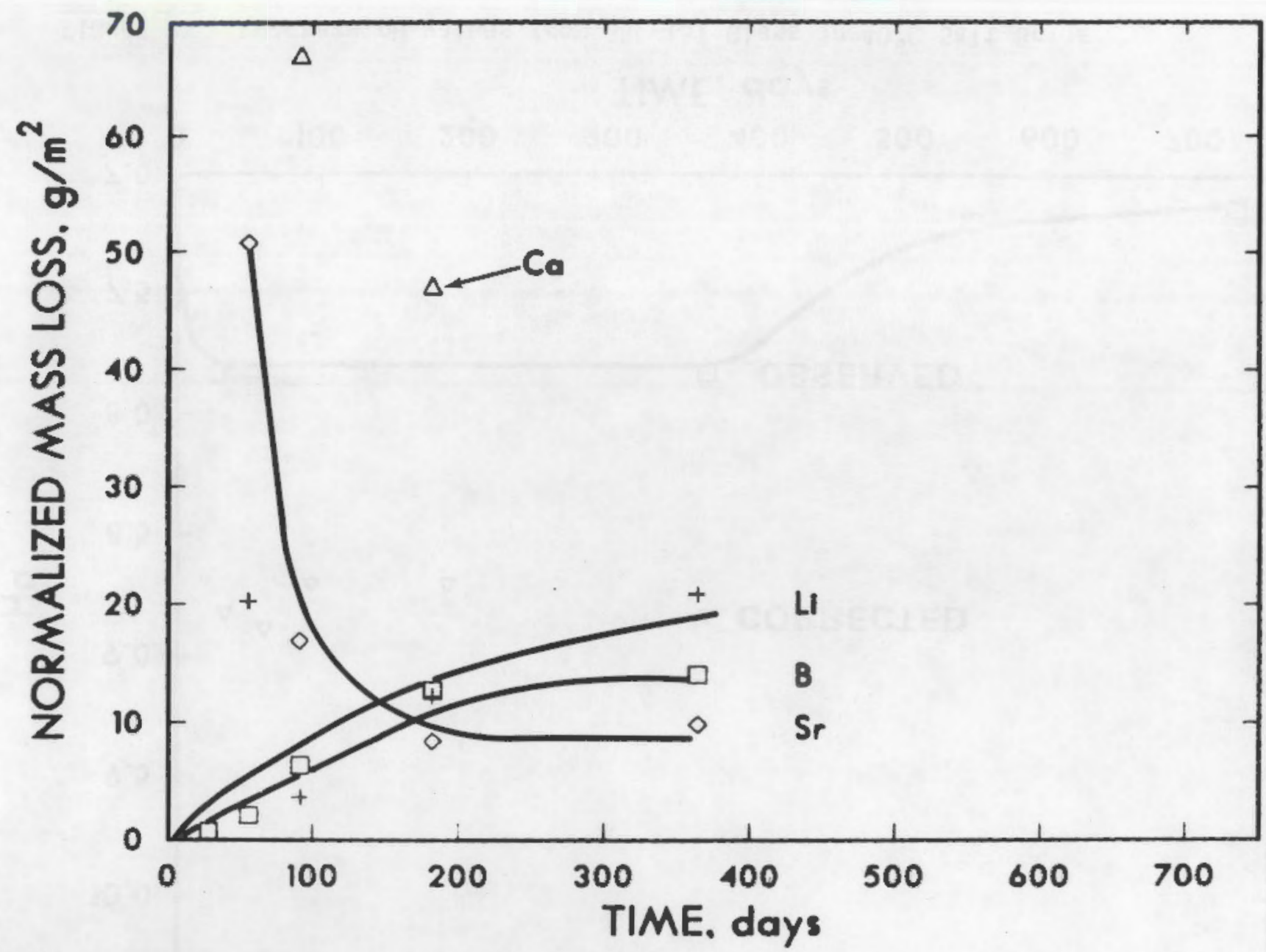

FIGURE 22. Normalized Mass Loss $\left(\mathrm{g} \cdot \mathrm{m}^{-3}\right)$ Results from the Leaching of SRL-131 Glass in $90^{\circ} \mathrm{C}$ Salt Brine 


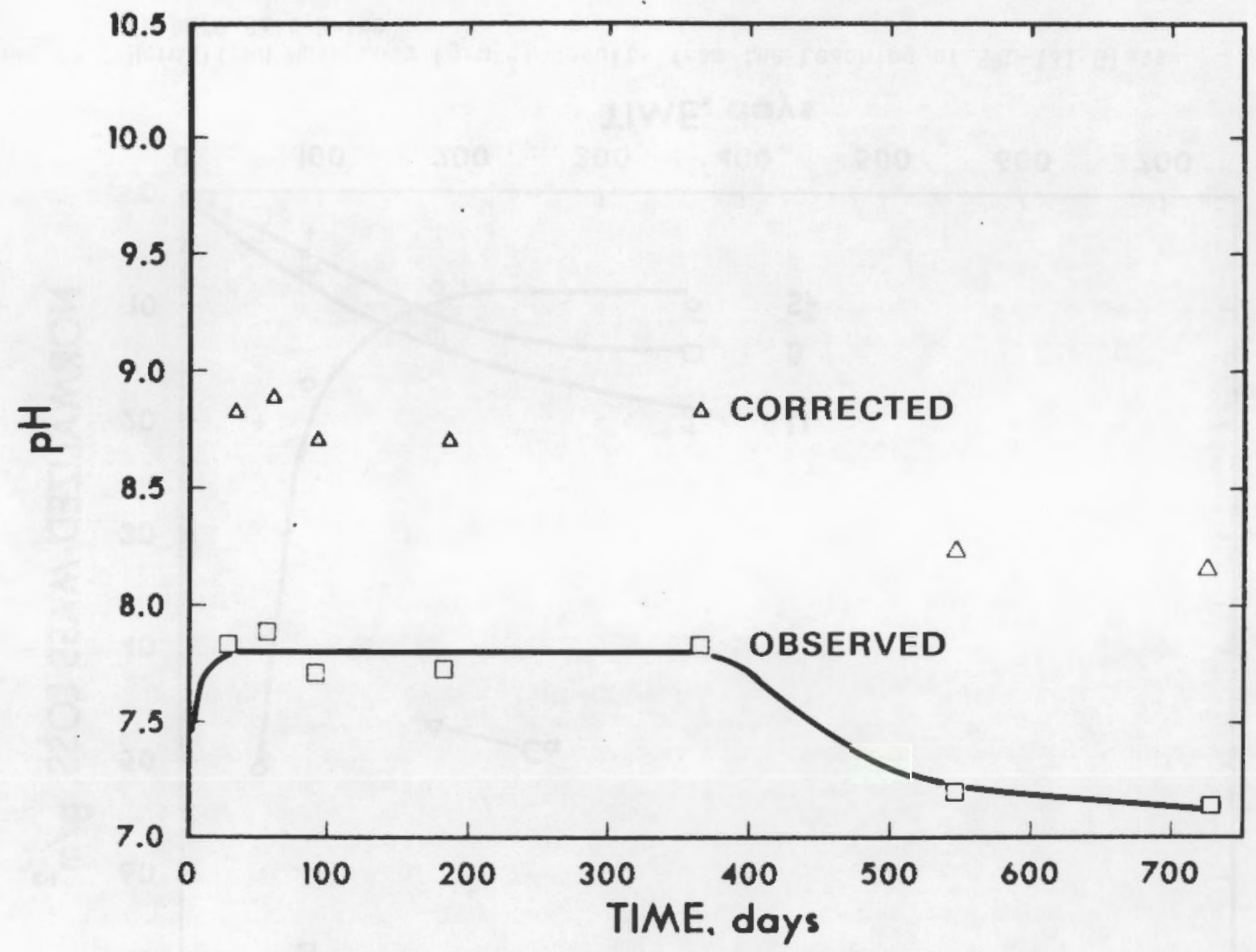

FIGURE 23. Leachate $\mathrm{pH}$ values from SRL-131 Glass in $40^{\circ} \mathrm{C}$ Salt Brine 


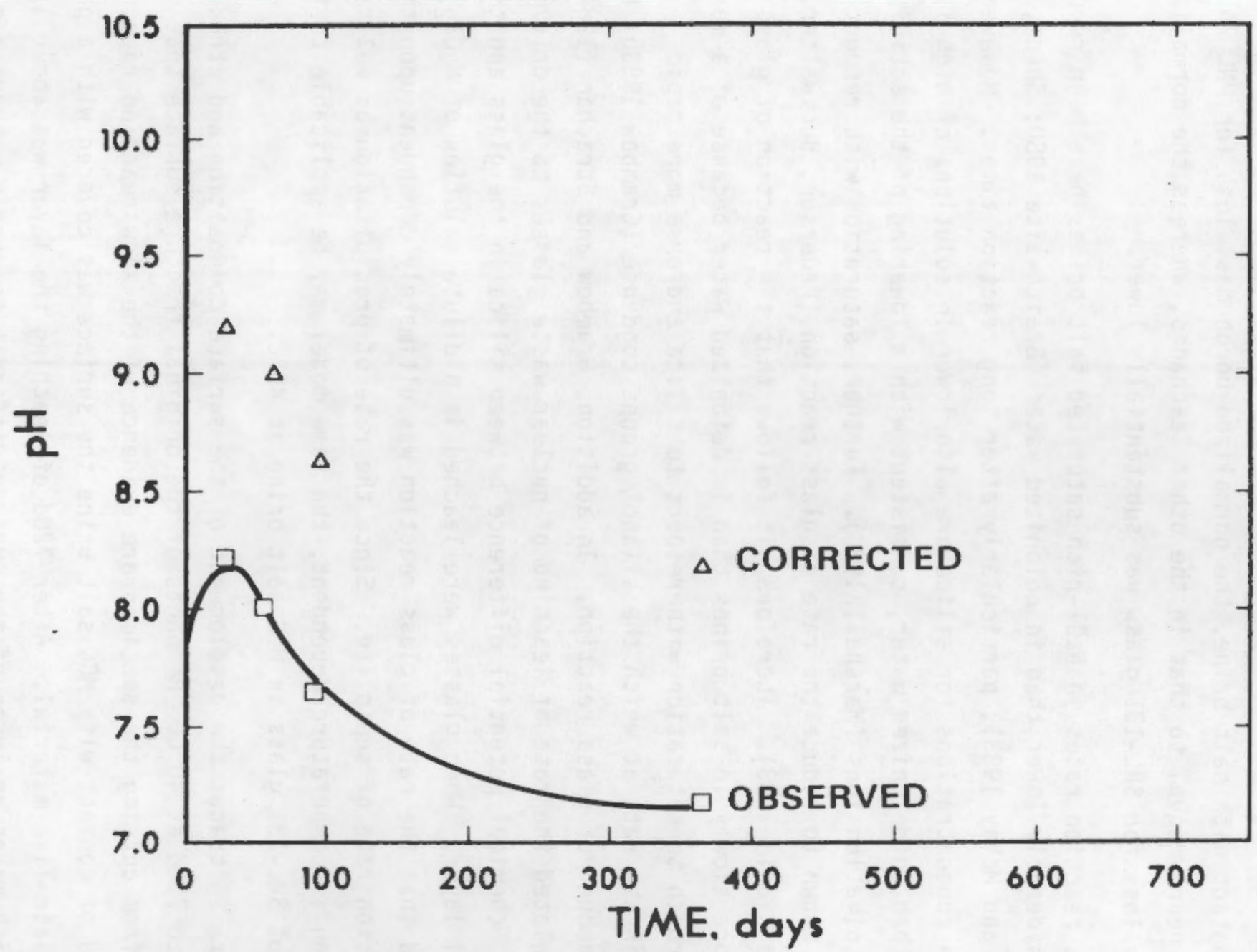

FIGURE 24. Leachate $\mathrm{pH}$ values from SRL-131 Glass in $90^{\circ} \mathrm{C}$ Salt Brine 
the other leachants. At shorter leach times a similar effect, although not as dramatic, was observed for PNL 76-68 glass (Strachan 1983). One of the main differences between PNL $76-68 \mathrm{glass}$ and SRL-131 glass is that, at $90^{\circ} \mathrm{C}$ after 365 d of contact with salt brine, the normalized boron mass loss for PNL 76-68 glass was nearly equal to that in the other leachants, whereas the normalized boron mass loss for SRL-131 glass was substantially lower.

Glass reaction rates in $\mathrm{NaCl}-$ rich saturated salt brines have been reported to be considerably lower than in deionized water (Braithwaite 1980; Shade, Pederson, and McVay 1983), particularly after long reaction times. However, saturation concentrations for silica are also lower in solutions of high ionic strength than in deionized water, consistent with a lowering of the activity of water by solvation ions (Marshall 1980). Further, saturation with respect to silica is known to reduce the rate of glass reaction (Pederson, Buckwalter, McVay, and Riddle 1983). Therefore, it follows that the reaction of glass will proceed more slowly in salt brines than in deionized water because of a more rapid approach to saturation with respect to silica and/or a more rapid increase in the rate at which the silanol groups condense (Grambow 1983b) for the same amount of glass reaction. In addition, Grambow and Strachan (1984) have correlated the rate of leaching of nuclear waste glasses to the driving force, eg. chemical potential difference between silica in the glass and that in the gel layer. When glasses were leached in a dilute solution of $\mathrm{MgCl}_{2}$, they found that the rate of glass reaction was ultimately dependent upon the precipitation rate of sepiolite. Since the rate of precipitation as well as dissolution is temperature dependent, the same model may be applicable to the reaction of SRL-131 glass in MCC salt brine at $40^{\circ} \mathrm{C}$.

Figure 25 traces the development of the surface composition and structure from $28 \mathrm{~d}$ to $728 \mathrm{~d}$ at $40^{\circ} \mathrm{C}$. Remnants of the original fracture surface that resulted from cutting the specimen are evidence of the slow reaction rate. After $728 \mathrm{~d}$ of contact with MCC salt brine the surface was covered with a protruding plate-like material. After $728 \mathrm{~d}$ of leaching the layer was about $1 \mu m$ thick, which makes analyses of the surface difficult to obtain without a significant contribution from the unreacted glass below the surface. However, the surface appears to be enriched in $\mathrm{Fe}$ and $\mathrm{Mg}$. This would be consistent with the 


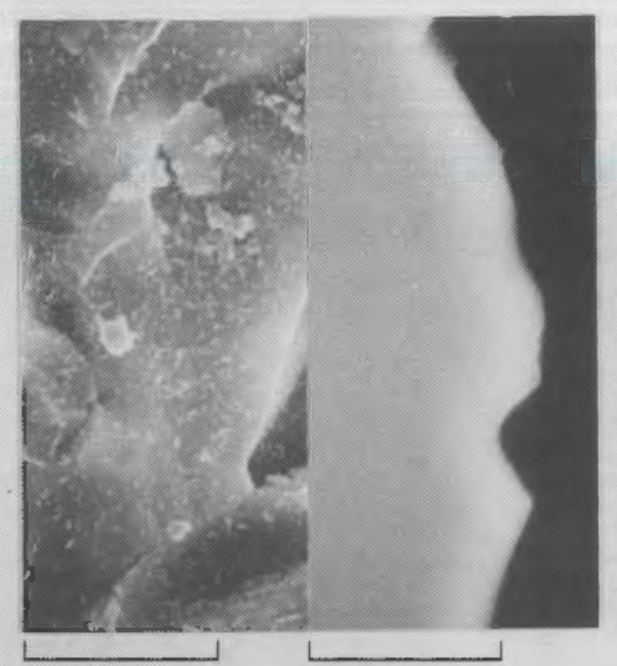

$10 \mu \mathrm{m}$

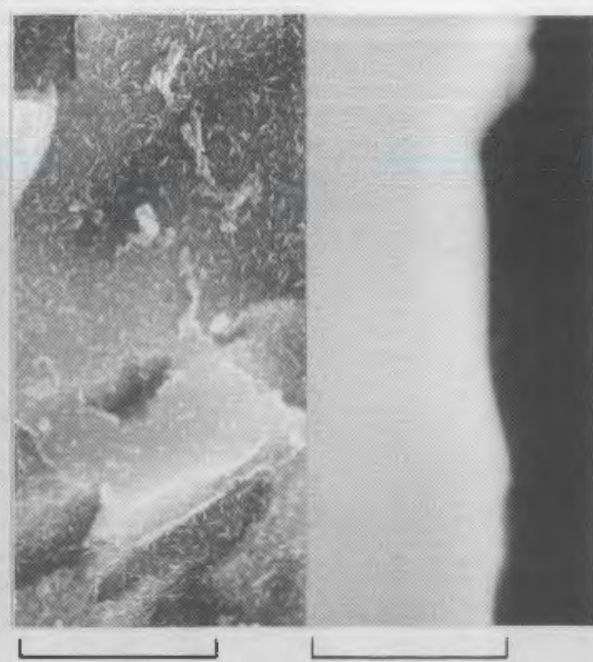

$10 \mu \mathrm{m}$ $91 \mathrm{~d}$

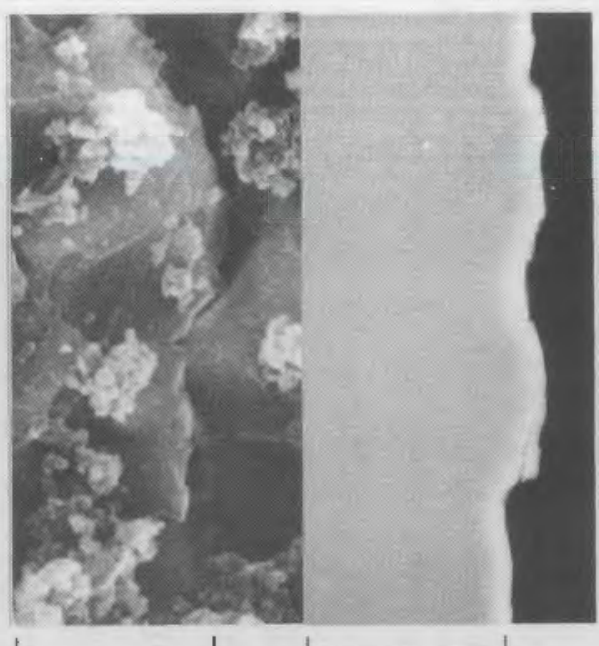

$10 \mu \mathrm{m}$

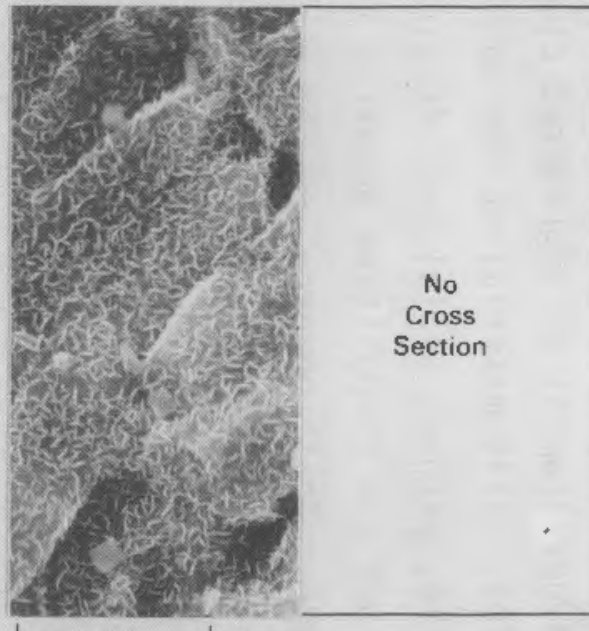

$10 \mu \mathrm{m}$

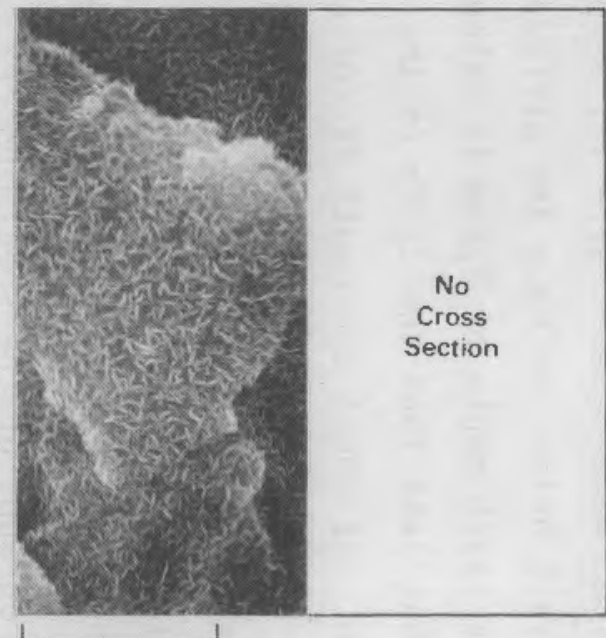

$10 \mu \mathrm{m}$

$728 d$

FIGURE 25. Photomicrographs from Specimens Leached in Salt Brine at $40^{\circ} \mathrm{C}$ : as-leached surface, cross section 
results from the other leachants, which showed the ease with which Mg tends to precipitate. In cross section the altered layer was too thin to obtain any composition information.

Figure 26 traces the development of the surface composition and structure of the specimens reacted at $90^{\circ} \mathrm{C}$ for up to $365 \mathrm{~d}$. For these specimens a much thicker gel layer developed - about $3 \mu \mathrm{m}$ after $365 \mathrm{~d}$. The absence of the cracks that resulted from the sawing, previously noted in the specimens leached at $40^{\circ} \mathrm{C}$ in deionized water (see Figure 7 ), is puzzling. If the normalized $B$ data for the $365 \mathrm{~d}$ salt brine leachate are divided by the density of the glass $\left(2.75 \mathrm{~g} / \mathrm{cm}^{3}\right)$, a leach depth of $5.8 \mu \mathrm{m}$ is calculated or nearly double the observed leach depth, but less than the depth of the cracks observed in the deionized water specimen. If the $5.8 \mu \mathrm{m}$ depth is correct, then the observed depth was the result of the removal of a substantial amount of material and/or the gel layer resulting from the reaction with salt brine was very dense - much more dense than the gel layers obtained by reaction with the other leachants. Evidence for highly dense gels has been reported elsewhere (Grambow and Strachan 1984).

Photomicrographs of the specimens reacted at $90^{\circ} \mathrm{C}$ from the $28 \mathrm{~d}$ and $91 \mathrm{~d}$ tests show the development of segregated clumps of apparently amorphous material (Figure 26). This material at $28 \mathrm{~d}$ was very enriched in $\mathrm{Mg}$ and appeared to be a Mg silicate, perhaps sepiolite. At 91d these clumps of material were still present but the composition appeared to have shifted toward a more silica rich Mg silicate. This, however, may be a natural result of the increased ionic strength of the solution and its effect on the solubility of silica (Marshall and Warakomski 1980, Chen and Marshall 1982) or a tendency for this amorphous material to have a variable composition that is $\mathrm{siO}_{2}-\mathrm{rich}$. After 365d of contact with the MCC salt brine these clumps of material were no longer visible as distinct entities but as small specks found throughout the gelsurface. No evidence of these Mg silicate clumps was found in the cross sections of the $365 \mathrm{~d}$ specimen. Instead, a rather uniform layer was found that was enriched in $\mathrm{Mg}, \mathrm{Fe}, \mathrm{Si}$, and other insoluble elements. Although not well resolved, there appeared to be an increasing amount of $\mathrm{Cl}^{-}$in the magnesiumrich silicates. This may indicate that the magnesium oxychloride reported by 

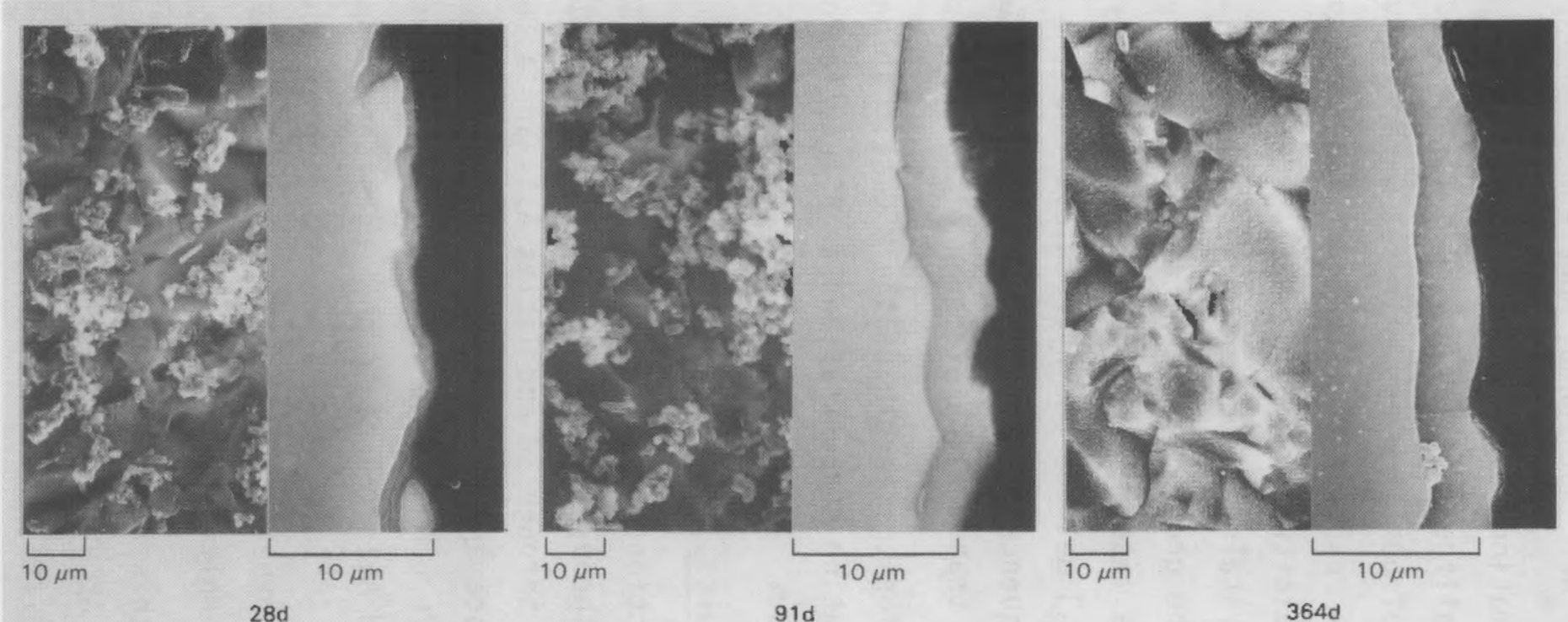

FIGURE 26. Photomicrographs from Specimens Leached in Salt Brine at $90^{\circ} \mathrm{C}$ as-leached surface, cross section 
the MCC (1984) was also present. Areas of magnesium oxychloride such as those reported by the MCC (1984) were not found, however.

Apparent crystal formation followed by the formation of a ge1, which either replaces the crystalline material or fills in the voids, has been observed in the reaction of basalt glass with sea water (Crovisier et al 1983a, 1983b). When basalt glass reacted with sea water, an amorphous gel layer was formed, upon which hydrotalcite $\left[\mathrm{Mg}_{6} \mathrm{Al}_{2} \mathrm{CO}_{3}(\mathrm{OH})_{16} 4 \mathrm{H}_{2} \mathrm{O}\right]$ grew. After a period of time, the hydrotalcite crystals were covered by an amorphous Si-Mg-Al gel followed in sequence by the growth of saponite, an ill-defined magnesiumalumino-silicate clay-like material, on the surface of the hydrotalcite, and serpentine $\left[\mathrm{Mg}_{6} \mathrm{Si}_{4}{ }_{10}(\mathrm{OH})_{8}\right]$ between the hydrotalcite and the hydrated glass surface. This complex sequence of crystallization is difficult to decipher without the aid of a good transmission electron microscopic study.

Because of the high ionic strength of the MCC salt brine, no attempt was made to calculate the solution concentrations as a function of glass dissolution using the PHREEQE code.

Synthetic Groundwater Results

Results from the reaction of SRL-131 glass in a synthetic groundwater are summarized in Figures 27 through 32, Figures A.14 through A.17, and Tables A.13 through A.16. Figures 27 through 30 and Tables $A .14$ and $A .16$ are the normalized elemental mass loss data and the remainder of the figures and tables are the analytical data in $\mathrm{mg} / \mathrm{L}$ or $\mathrm{pH}$. The $40^{\circ} \mathrm{C}$ data are summarized in figures 27 and 28 and Tables A.13 and A.15. Because the repository temperature is predicted to be greater than $40^{\circ} \mathrm{C}$ (DOE 1982b) and to decrease the cost of the test, experiments using synthetic groundwater as the leachant were continued from $365 \mathrm{~d}$ to $728 \mathrm{~d}$ at $90^{\circ} \mathrm{C}$ only.

The leachability of this glass in synthetic groundwater was about equal to that in deionized water. At $90^{\circ} \mathrm{C}$ the normalized releases of $\mathrm{B}$ (Figure 29) were about the same as in deionized water except that the rate of increase slowed earlier than in deionized water. Many elements show signs of solubility/sorption controls. These solubility/sorption controls can be seen by 


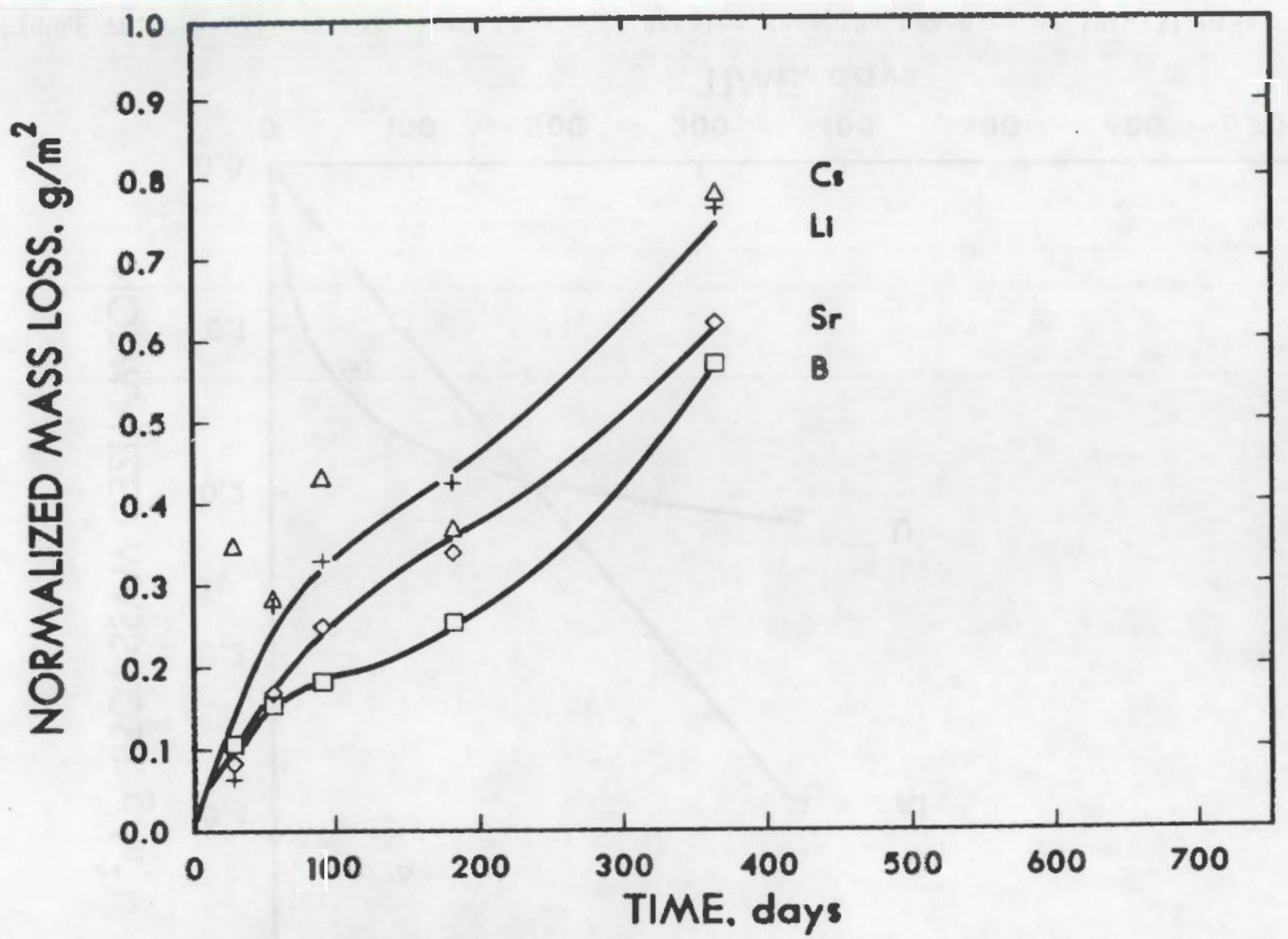

FIGURE 27. Normalized Mass Loss $\left(\mathrm{g} \cdot \mathrm{m}^{-3}\right)$ Results from the Leaching of SRL-131 Glass in $40^{\circ} \mathrm{C}$ Synthetic Groundwater 


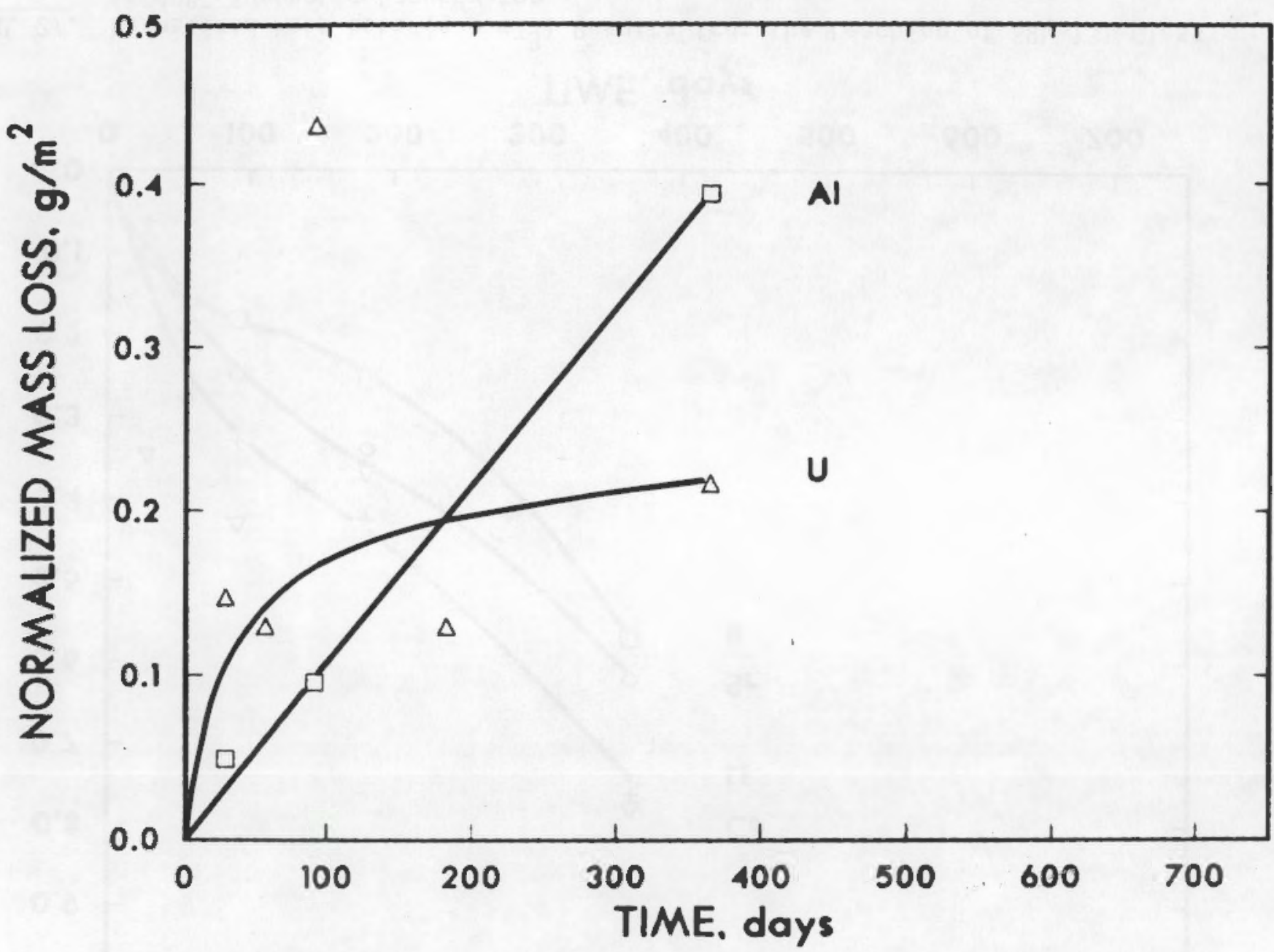

FIGURE 28. Normalized Mass Loss $\left(\mathrm{g} \cdot \mathrm{m}^{-3}\right)$ Results from the Leaching of SRL-131 Glass in $40^{\circ} \mathrm{C}$ Synthetic Groundwater 


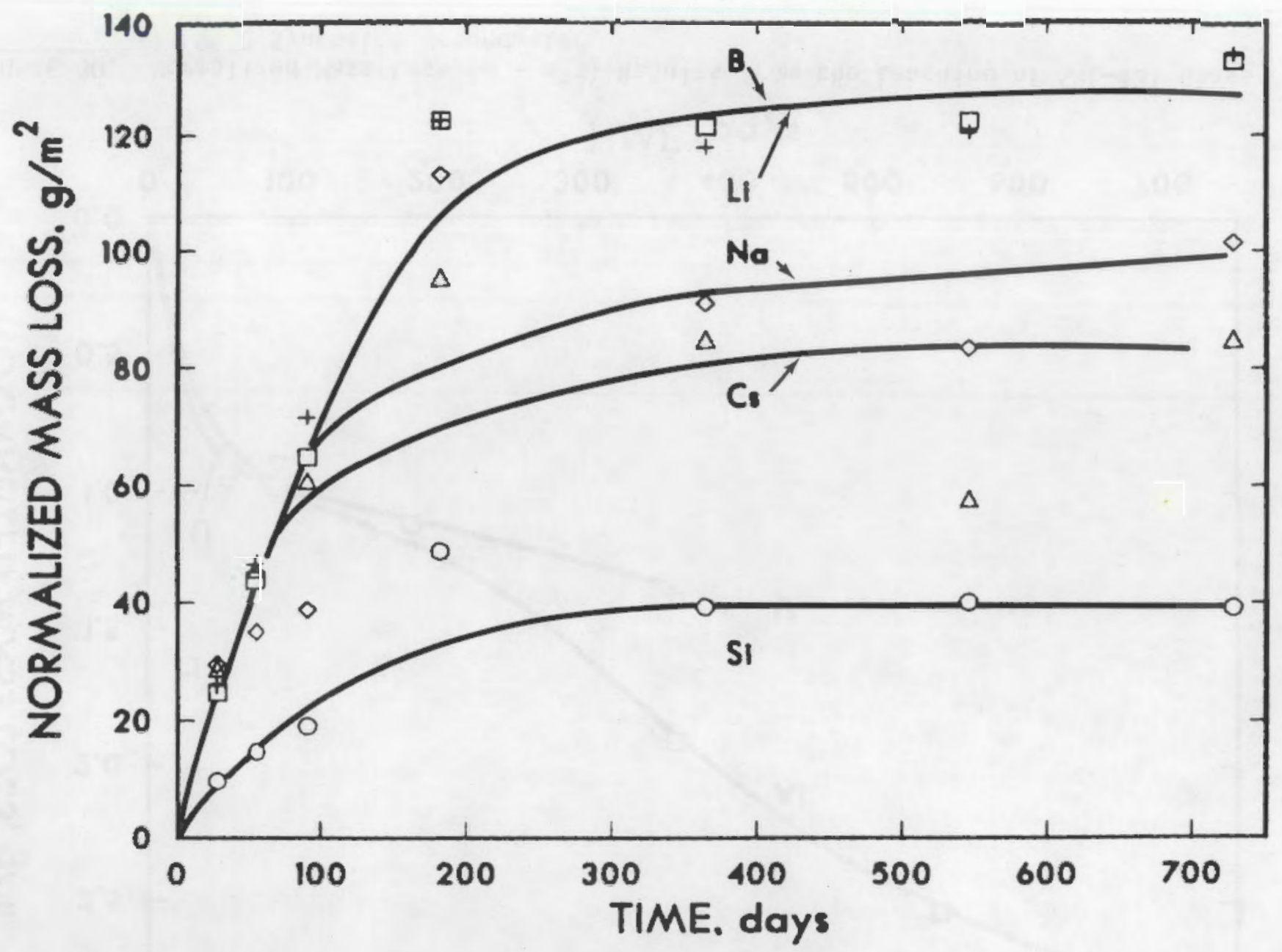

FIGURE 29. Normalized Mass Loss $\left(\mathrm{g} \cdot \mathrm{m}^{-3}\right)$ Results from the Leaching of SRL-131 Glass in $90^{\circ} \mathrm{C}$ Synthetic Groundwater 
के

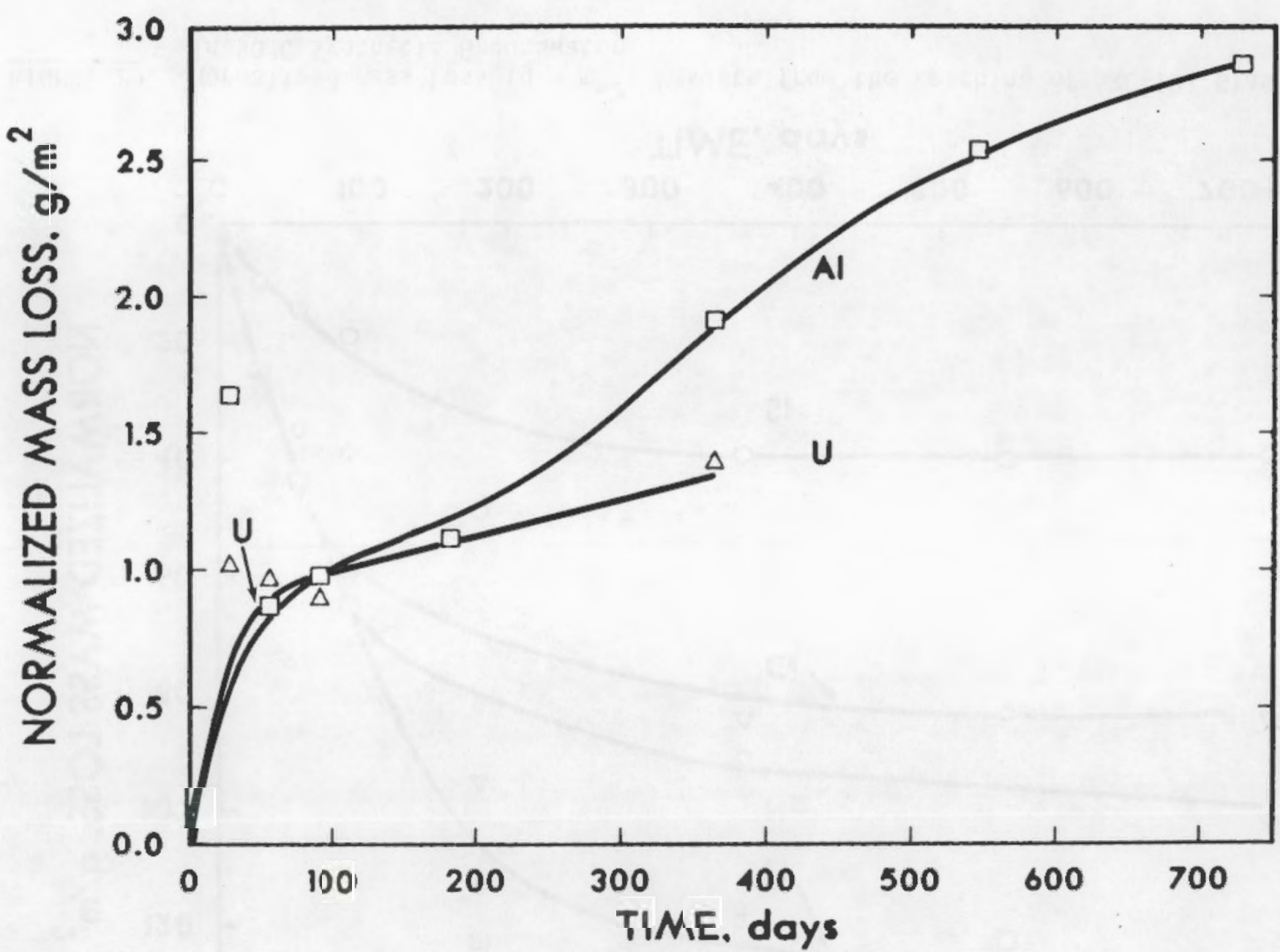

FIGURE 30. Normalized Mass Loss $\left(\mathrm{g} \cdot \mathrm{m}^{-3}\right)$ Results from the Leaching of SRL-131 Glass in $90^{\circ} \mathrm{C}$ Synthetic Groundwater 


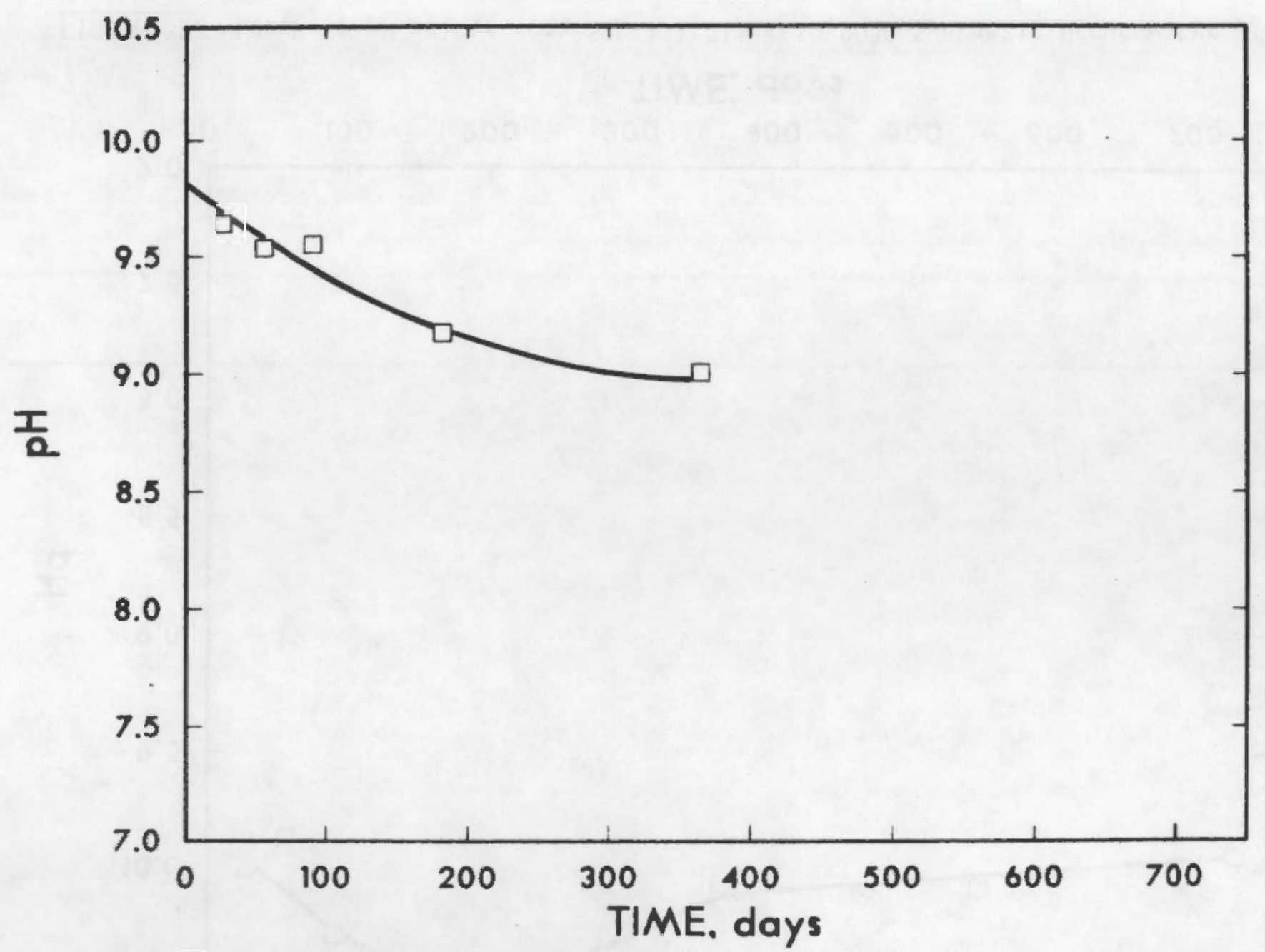

FIGURE 31. Leachate $\mathrm{pH}$ values from SRL-131 Glass in $40^{\circ} \mathrm{C}$ Synthetic Groundwater 


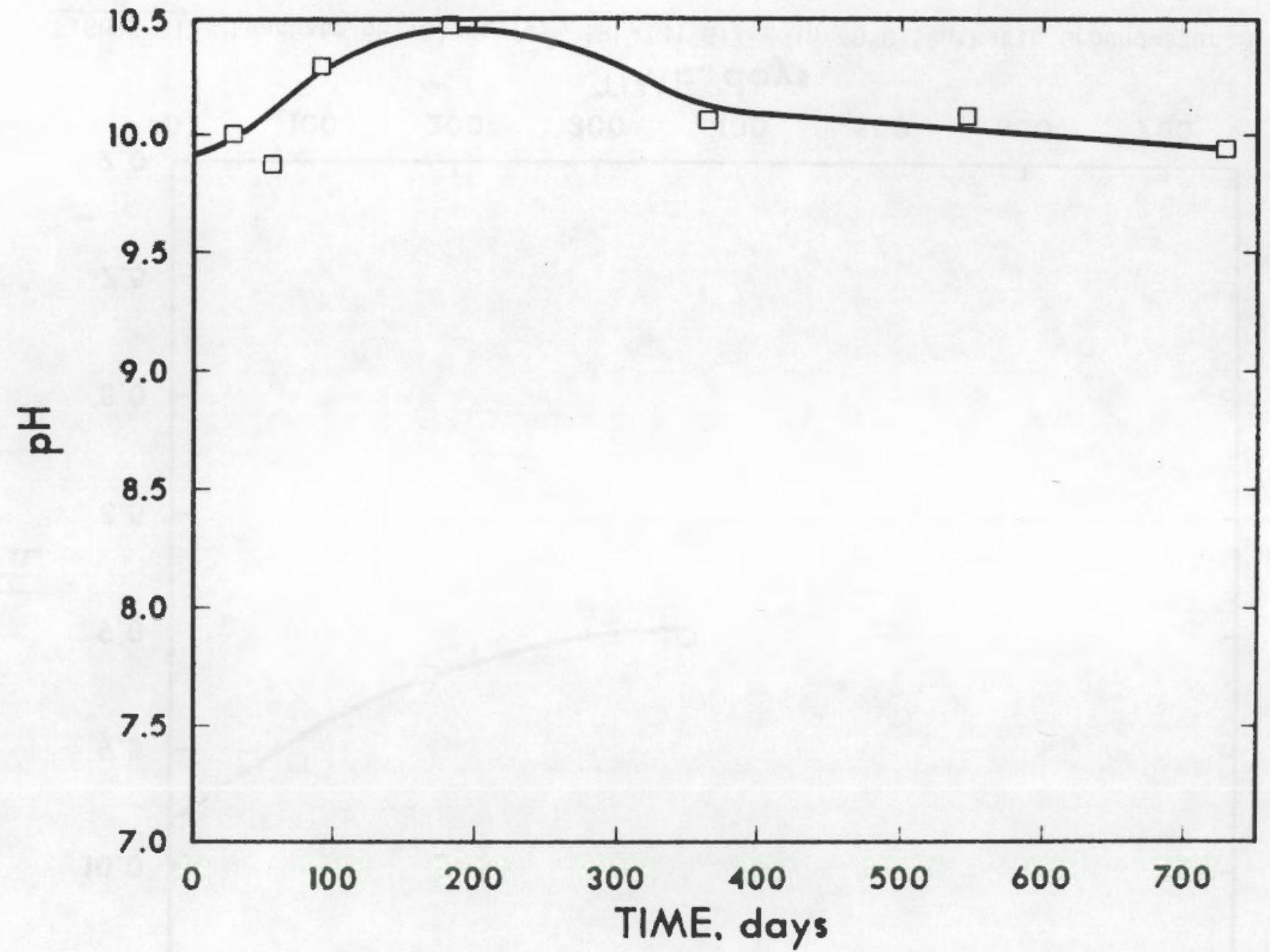

FIGURE 32. Leachate $\mathrm{pH}$ values from SRL-131 Glass in $90^{\circ} \mathrm{C}$ Synthetic Groundwater 
comparing the data plotted in figures 29 and 30 . Cesium showed higher normalized elemental mass losses than those observed in the deionized water tests (see Figures 3 and 29) whereas the Si losses were lower. As expected from the solution analyses, very little reaction of the glass with synthetic groundwater at $40^{\circ} \mathrm{C}$ was evident (Figure 33 ). Calcium in the synthetic groundwater reacted quite rapidly with the glass at $90^{\circ} \mathrm{C}$ and decreased to near detection limits. It is uncertain if this is due to sorption or to precipitation, although calcium in the starting solution calculates to be saturated with respect to calcite $\left(\mathrm{CaCO}_{3}\right)$ and fluorite $\left(\mathrm{CaF}_{2}\right)$. No anion analyses were performed so precipitation of fluorite cannot be confirmed. Strontium behaved in a fashion similar to $\mathrm{Ca}$. Uranium remained at concentrations of less than $1 \mathrm{mg} / \mathrm{L}$ even under these oxidizing conditions.

As expected from the solution analyses, very little reaction of the glass with synthetic groundwater at $40^{\circ} \mathrm{C}$ was evident (Figure 33 ). The alteration layer was not detectable in the specimens examined. The light areas shown in Figure 33 are due to charging and not to any physical differences in the specimen composition or morphology.

Solid state results from the specimens leached in synthetic groundwater at $90^{\circ} \mathrm{C}$ indicate that the surfaces were generally enriched in $\mathrm{Mg}, \mathrm{Si}, \mathrm{Ca}, \mathrm{Mn}, \mathrm{Fe}$, and $\mathrm{Ni}$. At $365 \mathrm{~d}, 546 \mathrm{~d}$, and $728 \mathrm{~d}$ at $90^{\circ} \mathrm{C}$ the specimens appeared to have small areas with very high enrichments of $\mathrm{Mg}$ and $\mathrm{Si}$ (Figure 33). This result would point to a Mg silicate as a solubility control for both $\mathrm{Si}$ and $\mathrm{Mg}$. Both the glass and the synthetic groundwater contained $\mathrm{Mg}, 1.24 \%$ and $0.1 \mathrm{mg} / \mathrm{L}$, respectively. In cross section, the gel layer appeared less complex than that observed for the deionized water specimens. The layer was generally uniform with respect to the concentrations of many elements. Electron microprobe studies of the $728 \mathrm{~d}$ specimen in cross section indicated that, from the unleached glass to a distance one-half of the layer thickness, the gel layer contained as much $\mathrm{Na}$ as the glass. In addition, there was a thin layer, perhaps 1 to $2 \mathrm{~m}$ thick, that is enriched in $\mathrm{Na}$ over the rest of the gel layer. These results are consistent with the PHREEQE calculations which show that the solution was nearly saturated with respect to analcime. Specimens leached for $28 \mathrm{~d}$ showed very high surface enrichments of $\mathrm{Ca}$. This is in agreement with the 


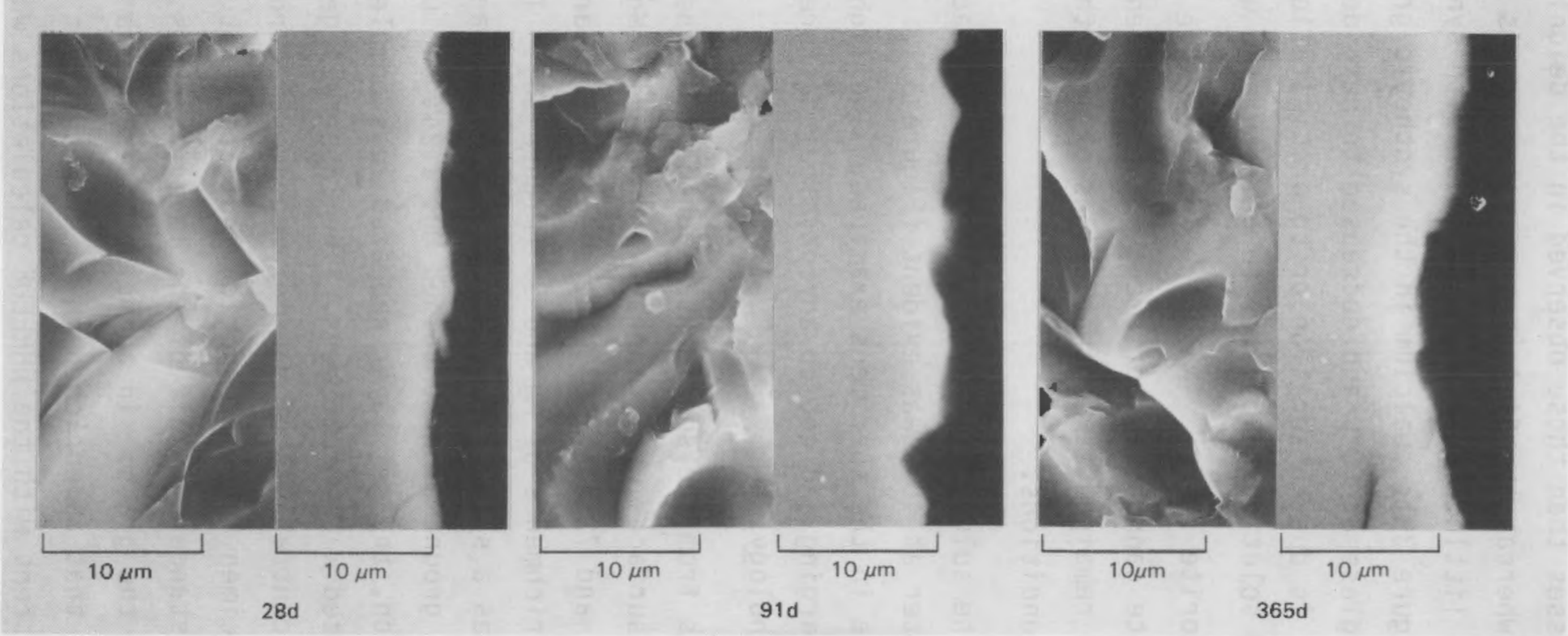

FIGURE 33. Photomicrographs from Specimens Leached in Synthetic Groundwater at $40^{\circ} \mathrm{C}$ : as-leached surface, cross section 
solution analyses which showed a rapid decrease in the Ca concentration originally present. Also in agreement with these observations is the fact that the original solution calculates to be oversaturated with respect to the Ca minerals calcite, fluorite $\left(\mathrm{CaF}_{2}\right)$, and leonhardite. As the glass continues to react, the surface analyses show a decreasing concentration of Ca on the surface. This may be due to the relative enrichment of the other elements or to a general spreading out of the Ca throughout the gel layer. Some areas of localized high concentrations of $\mathrm{Ca}$ were noted, however.

Calculations using PHREEQE indicate that the initial solution at $40^{\circ} \mathrm{C}$ was oversaturated with respect to calcite, fluorite $\left(\mathrm{CaF}_{2}\right)$, and leonhardite, but because there was no decrease in the observed $\mathrm{Ca}$ concentration, neither phase was included in the calculation which led to Figure 33 . The reason the Ca concentration remained constant is probably due to the fact that there was insufficient glass reaction at $40^{\circ} \mathrm{C}$ and, hence, insufficient sorption/ nucleation sites for any significant reaction to occur. At $90^{\circ} \mathrm{C}$ (see below) sufficient reaction took place that the Ca concentration was significantly reduced.

Calculations for the $90^{\circ} \mathrm{C}$ data were done using the PHREEQE code and included solubility control from the solids $\mathrm{Fe}(\mathrm{OH})_{3}, \mathrm{Nd}(\mathrm{OH})_{3}$, rhodochrosite, leonhardite, hydroxyapatite, sepiolite, calcite, analcime, and amorphous $\mathrm{SiO}_{2}$. The results of this calculation are shown in Figure 36. Calcium was first controlled by calcite, then by calcite and leonhardite, followed by the dissolution of calcite in favor of hydroxyapatite and leonhardite. Leonhardite controlled Al up to a reaction progress of about $1000 \mathrm{~g} / \mathrm{m}^{3}$ after which leonhardite dissolved in favor of analcime which became the only control for Al. Silicon was controlled by sepiolite during the early reaction of the glass with synthetic groundwater. From about $365 \mathrm{~d}$ to $728 \mathrm{~d}$ analcime was calculated to be the solubility control for Si. There is good fit between the calculated and observed data for $\mathrm{Si}, \mathrm{Al}, \mathrm{Mn}$, and $\mathrm{Fe}$. The Mg data appeared to be quite oversaturated with respect to sepiolite, although the data from the last $365 \mathrm{~d}$ of the reaction period seemed to be approaching the calculated solution concentrations. The Ca data seem to be scattered about the calculated solution concentrations. 

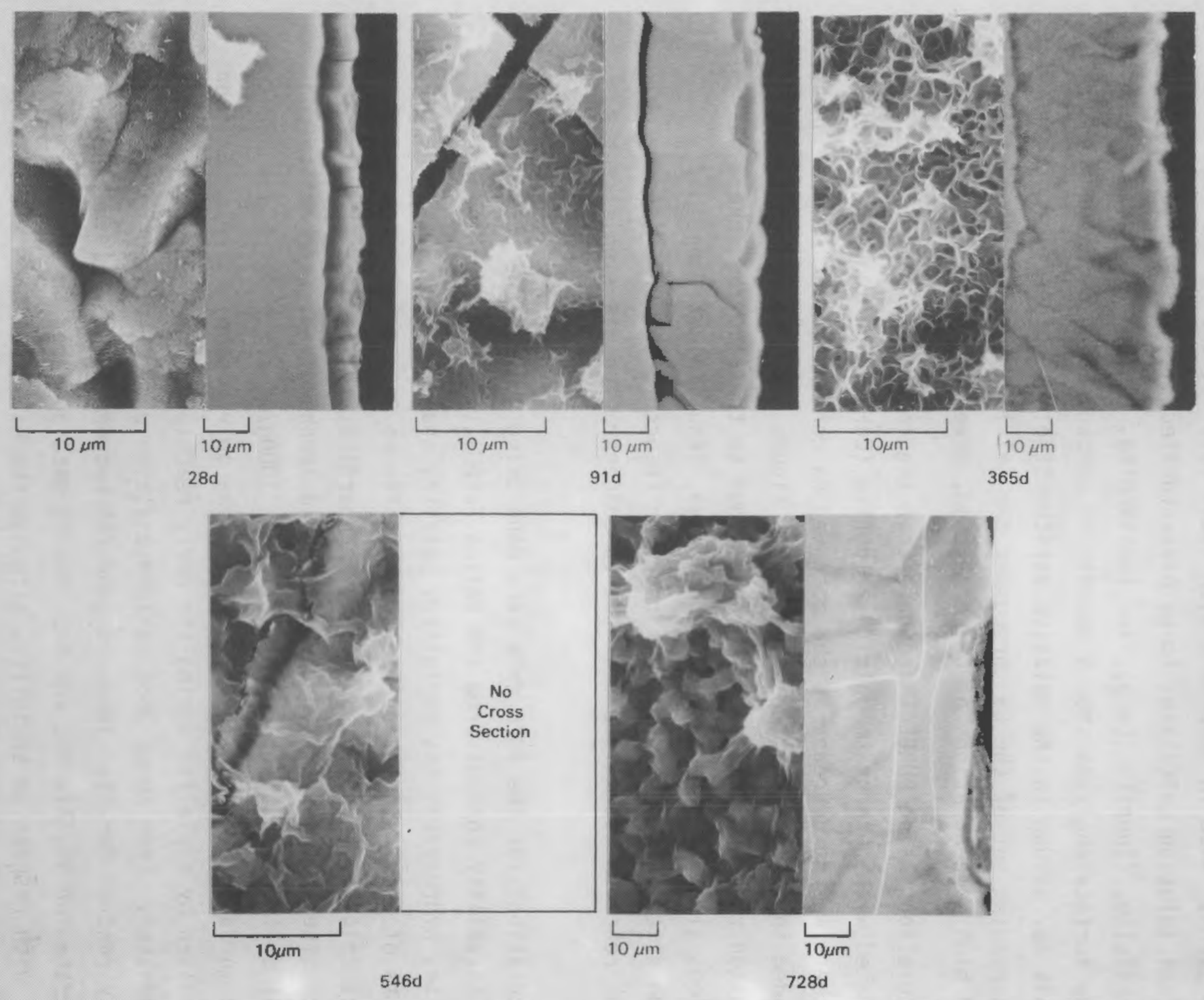

FIGURE 34. Photomicrographs from Specimens Leached in Synthetic Ground-water at $90^{\circ} \mathrm{C}$ : as-leached surface, cross section 


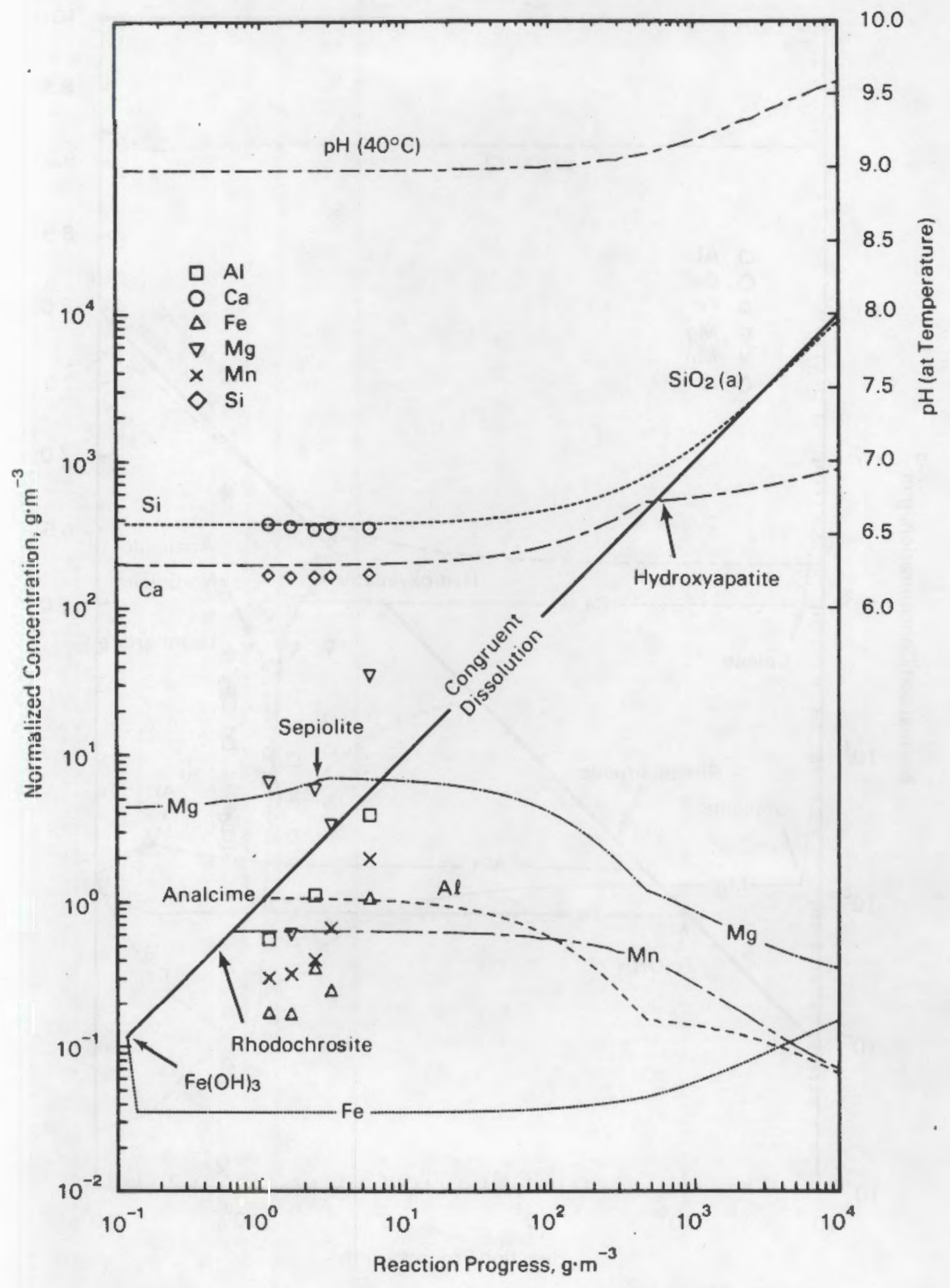

FIGURE 35. Calculated and 0bserved Data From SRL-131 Glass in Synthetic Groundwater at $40^{\circ} \mathrm{C}$ 


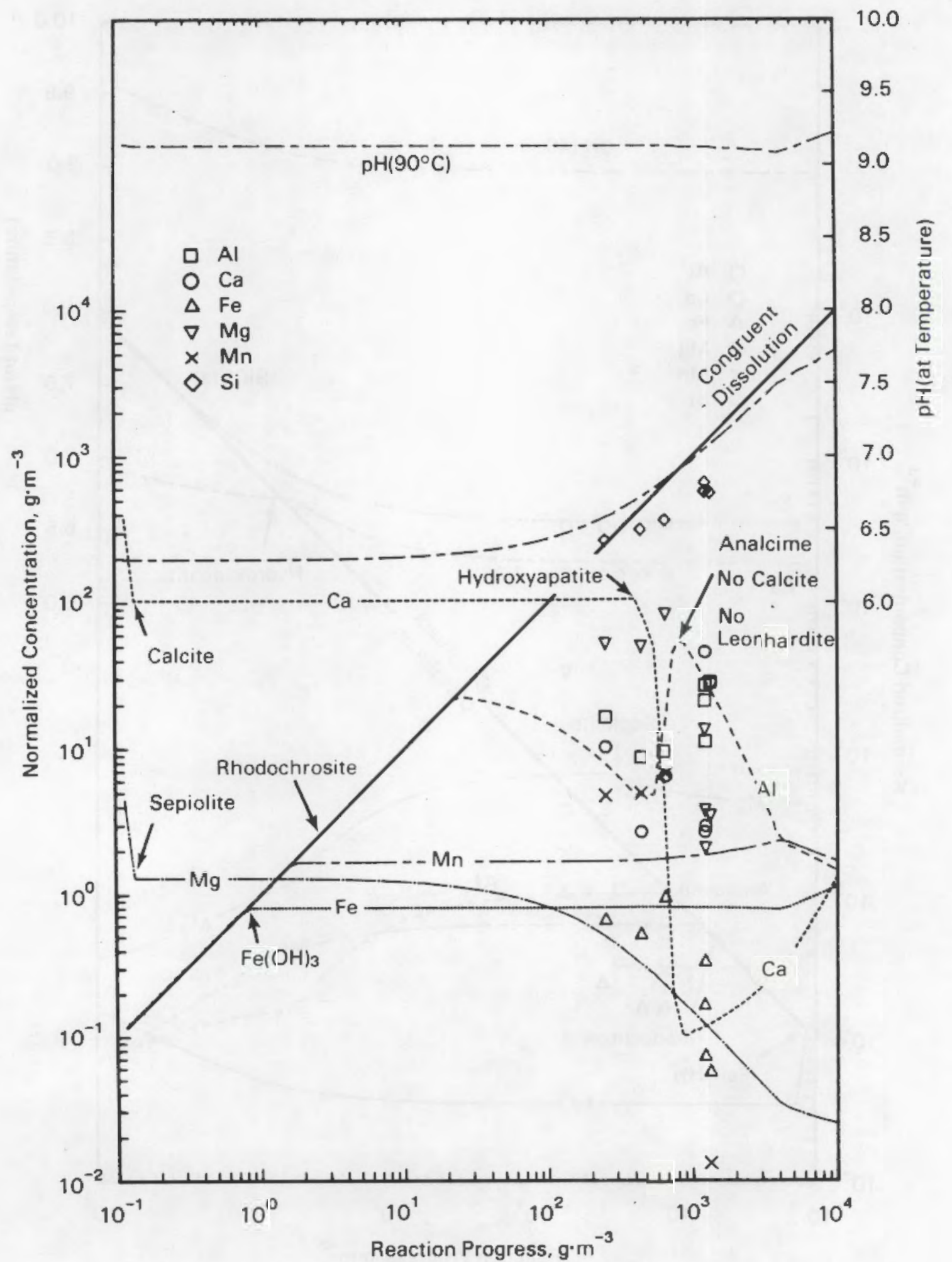

FIGURE 36. Calculated and Observed Data From SRL-131 Glass in Synthetic Groundwater at $90^{\circ} \mathrm{C}$ 
COMPARISON OF RESULTS FROM ALL LEACHANTS

Comparison of the leach results at $90^{\circ} \mathrm{C}$ from the three non-salt brine leachants leads to some interesting observations about the effect of the Si concentration on the leachability of borosilicate glasses. The order of decreasing leachability would appear to be, from the two-year results, deionized water $\cong$ synthetic groundwater > silicate water. Based on the Si concentrations in the original leachants one might have predicted that the leachability of SRL-13l glass would be nearly equal in both silicate water and synthetic groundwater. Although the pH of the starting leachants was quite different, the final $\mathrm{pH}$ values were within 0.5 units of each other. This difference in pH does not seem to affect the "solubility" of silica in these systems since the $S i$ concentrations were equal within experimental error. Although the modeling results are only qualitative indicators of the behavior of the glass in these leachants, there are differences. Using the same phases in the PHREEQE calculations for the three leachants leads to different behavior of the various dissolved constituents. Iron, for instance, is predicted to have a lower solubility in the silicate water than in the other two leachants at the $\mathrm{pH}$ and reaction progress values of interest. It has been suggested by Grambow and Strachan (1984) and Strachan, Krupka, and Grambow (1984) that iron in the gel layer plays an important role in the kinetics of waste glass dissolution. Because of the sorption sites that are provided by the amorphous iron hydroxide/hydrated oxide, the increased solubility of the iron phase may lead to an decrease in the sorption sites for constituents such as silicic acid. It has been shown that increasing the solubility of $\mathrm{Fe}$ and other normally insoluble elements by the addition of a strong complexant allows Si to leach congruently with the remainder of the glass constituents even though the $\mathrm{Si}$ is not complexed (MCC 1982). Thus, it would appear that the behavior of the glass in various leachants may well be linked to the formation of solid phases which differ depending upon the chemistry of the leachant.

Solid state analyses revealed the complexity of the glass/water reaction. Examination of the photomicrographs show a complex gel layer developed over the relatively short time period of $2 \mathrm{y}$. The specimens leached in deionized water had multiple layers and areas within those layers with feather-like morphology 
which appeared to be crystalline in the photomicrographs, but were $x$-ray amorphous. Large $(10, \mathrm{~m})$ areas, highly enriched in Mn with significant concentrations of $\mathrm{Fe}$ and $\mathrm{Si}$, clearly indicated that well crystallized material should form if the experiments were carried out longer. Development of highly enriched areas of $\mathrm{Mg}$ silicates on the specimens leached in synthetic groundwater as well as in the salt brine point to the development of a Mg phase that is quite stable under a wide range of solution conditions. In the case of the synthetic groundwater only trace quantities of Mg were present in the leachant whereas $\mathrm{Mg}$ is a major constituent in the salt brine.

The development of the U-rich area in the specimens leached in deionized water at $90^{\circ} \mathrm{C}$ points to the complexity of the mechanism by which these solids precipitate and, perhaps, the complexity of the gel layer chemistry. The U-rich layer appeared to have migrated with and toward the glass/gel layer interface, becoming more concentrated, and developing apparent crystallinity. These solids need to be investigated using a higher resolution microscope such as a transmission electron microscope in an attempt to determine the mechanisms by which these solids form. Uranium in the deionized water leachant might be controlled by the solid phase that formed near the glass/gel layer interface.

Uranium in the leachates remained below $1 \mathrm{mg} / \mathrm{L}$ for the first $365 \mathrm{~d}$ of the leach test in all leachants. Unfortunately, the $U$ analyses were not performed on the leachates taken after $365 d$. The solubility of U(VI) is expected to increase with increasing $\mathrm{pH}$ in carbonate-free solutions at $25^{\circ} \mathrm{C}$ (Krupka et al 1984) but the behavior at elevated temperatures has not been fully investigated. The presence of carbonate in the leachates used in the work reported here undoubtedly increased the solubility of the U-bearing solid, but the effect on the solubility of the complex leachant/leachate used in this work cannot be estimated. However, the solubility of schoepite $\left(\mathrm{UO}_{3} \cdot 2 \mathrm{H}_{2} \mathrm{O}\right)$ in the range of $\mathrm{pH}$ values for the leachates of this study is in the range $0.4 \mathrm{mg} \mathrm{U} / \mathrm{L}$ to $20 \mathrm{mg} \mathrm{U} / \mathrm{L}$ (Krupka et al 1984). While the two ranges overlap, there is no evidence to conclude that the solid that controls the solution concentration of $U$ in these leach experinents is schoepite. In the case of the salt brine leachant solid phases which might control the $U$ concentration are alkali or alkaline-earth uranates. A sodium uranate may also be possible in the other leachants because of the relatively high Na concentrations. 
SUMMARY AND CONCLUSIONS

Leaching studies of SRL-131 simulated defense nuclear waste glass have been carried out to two years duration, in leachants expected to be relevant to geologic sites being considered for a high-level nuclear waste repository. The long-term leaching results were in agreement with modeling calculations using the PHREEQE geochemical code. Validation of modeling calculations using experimental data corresponding to leaching times as long as possible is the most defensible means of predicting release characteristics over repositoryrelevant times.

The leachability of SRL-131 glass, from results up to two years, followed the trend: deionized water $\cong$ synthetic groundwater > silicate water > salt brine. The relative saturation fraction of silicic acid in the leachant apparently does play an important role in determining the glass reactivity, although other factors must also be considered. That salt brines gave the lowest leach rates is consistent with a known decreased solubility of $\mathrm{SiO}_{2}$-bearing solids in solutions of high ionic strength. For the same reasons that the $\mathrm{SiO}_{2}$ solubility is reduced in high ionic strength solutions, the rate at which the silanol groups condense (Grambow 1983b) may increase at high ionic strengths. This interpretation is also consistent with the work of Weres, Yee, and Tsao. Deionized water obviously contained no measurable silicic acid initially, and thus, required the greatest extent of glass reaction to. saturate the leachant. On the other hand, synthetic groundwater yielded a higher reaction rate than might be expected on the basis of the silicic acid solution concentration alone, demonstrating the limitation of any model based solely on that factor. Modeling calculations yielded different solid phases as a function of reaction progress and leachant composition. Although the actual presence of all the calculated solid phases could not be verified experimentally, the high degree of agreement between calculated and experimental solution concentrations implies that the complete glass-water-alteration product system must be considered to understand the behavior of the glass in the various leachants. Leaching of the glass may depend critically on such reactions as the kinetics of alteration product formation, especially for those alteration products containing $\mathrm{SiO}_{2}$. In turn, the rate at which the alteration phases form is also a function of the leachant chemistry. 
Temperature appears to have two effects. The kinetic effect slows the rate of reaction by one to two orders of magnitude when the temperature is lowered from $90^{\circ} \mathrm{C}$ to $40^{\circ} \mathrm{C}$. However, a complicating effect is that of predicted changes in the chemistry of the solids/solution system. Although there are insufficient data to make the PHREEQE calculations quantitative, there are qualitative indications that the chemistry of the leachate and the solubility of the solids change significantly with temperature, which will certainly cause differences in the dissolution behavior of the glass. While PHREEQE or some other geochemical code can be used to forecast some of the changes in the chemistry of the glass/water reaction, these codes do not address the important issue of the mechanism and the kinetics of the glass/water reaction.

Illustrative of the complex interplay of kinetics and thermodynamics are the $U$ data from the deionized water experiments at $90^{\circ} \mathrm{C}$. The data suggest that, during the early stages of the glass/water reaction, the kinetics of dissolution cause the $U$ to precipitate as an amorphous material spread throughout the alteration layer. However, as the kinetics of dissolution slowed, the $U$ began to precipitate at a location in the alteration layer of minimum solubility, near the glass/layer interface. The minimum in the $U$ solubility within the alteration layer was probably a function of the redox potential of the area and the local chemistry. Other elements, such as Fe, Mn, etc., inight be expected to show similar behavior as a function of time. The long-term behavior of dissolved constituents in the solutions that contact nuclear waste forms will, in general, depend on the complex chemistry and kinetics of the waste package/water interactions. These results point to the need for repository-relevant tests of very long duration. 


\section{REFERENCES}

Aargaard, P. and H. C. Helgeson. 1982. "Thermodynamic and Kinetic Constraints on Reaction Rates Among Minerals and Aqueous Solutions. I. Theoretical Considerations." American Journal of Science, 282:237-285.

Braithwaite, J. W. 1980. Brine Chemistry Effects on the Durability of a Simulated Nuclear Waste Glass. In Scientific Basis for Nuclear Waste Management II, C. J. M. Northrup, Jr., Plenum Press, New York, NY.

Bunker, B. C., G. W. Arnold, E. K. Beauchamp, and D. E. Day. 1983.

"Mechanisms for Alkali Leaching in Mixed Na-K-Silicate Glasses." J. NonCrystalline Solids 58:295-322.

Chen, C. A. and W. L. Marshall. 1982. "Amorphous Silica Solubilities - IV. Behavior in Pure Water and Aqueous Sodium Chloride, Sodium Sulfate, Magnesium Chloride, and Magnesium Sulfate Solutions up to $350^{\circ} \mathrm{C}$." Geochimica et Cosmochimica Acta, 46:279-280.

Chick, L. A. and L. R. Pederson. 1984. The Relationship Between Reaction Layer Thickness and Leach Rate for Nuclear Waste Glasses. In Scientific Basis for Nuclear Waste Management VII, G. L. McVay, ed. North-Holland, New York, NY.

Crovisier, J., et al. 1983a. "Experimental Seawater-Basaltic Glass Interaction at Low Temperatures $\left(90-50-25\right.$ and $\left.3^{\circ} \mathrm{C}\right)$. Study of Early Developed Phases by Electron Microscopy and X-ray Photoelectron Spectrometry." Water/Rock Interaction, 4:.

Crovisier, J., et al. 1983b. "Experimental Seawater-Basaltic Glass Interaction at $50^{\circ} \mathrm{C}$ : Study of Early Developed Phases by Electron Microscopy and $X$-ray Photoelectron Spectrometry." Geochimica et Cosmochimica Acta, $47: 377-387$.

Cotton, F. A. and G. Wilkinson. 1980. Advanced Inorganic Chemistry. John Wiley and Sons, New York, NY.

Department of Energy (DOE). 1982a. Final Environmental Impact Statement. Defense Waste Processing Facility Savannah River Plant, Aiken, SC. DOE/EIS0082. U.S. Department of Energy, Washington, D.C.

Department of Energy (DOE). 1982b. Site Characterization Report for the Basalt Waste Isolation Project. DOE/RL 82-3. Department of Energy, Richland Operations, Richland, WA.

Grambow, B. E. 1983a. "Geochemical Modeling of the Reaction Between Glass and Aqueous Solution." In Advances in Ceramics. Nuclear Was te Management. Volume 8, G. G. Wicks and W. A. Ross, eds. American Ceramic Society, Columbus, $\mathrm{OH}$. 
Grambow, B. E. 1983b. "Influence of Saturation on the Leaching of Borosilicate Nuclear Waste Glasses." Glastechnische Berichte XIII. Internationaler Glaskongress, 56:566-571.

Grambow, 8. E. and D. M. Strachan. 1983. Leaching of Nuclear Waste Glasses Under Near-Saturation Conditions. In Scientific Basis for Nuclear Waste Management VII, G. L. McVay, ed., North-Kolland, New York, NY.

Jones, T. E. 1982. Reference Material Chemistry - Synthetic Groundwater formulation. RHO-BW-ST-37 P. Rockwell Hanford Operations, Richland, WA.

Krupka, K. M., D. Rai, R. W. Fulton, and R. G. Strickert. 1984. Solubility Data for U(VI) Hydroxide and $N p$ (IV) Hydrous Oxide: Application of $M C C-3$ Methodology. PNL-SA-12324. Pacific Northwest Laboratory, Richland, WA. (also to appear in Scientific 8asis for Nuclear Waste Management VIII, Materials Research Society, Pittsburgh, PA)

Langton, C. A., M. D. Dukes, and R. V. Simmons, 1984. Cement-Based Waste Forms for Disposal of Savannah River Plant Low-Level Radioactive Salt Waste. In Scientific Basis for Nuclear Waste Managenent, G. L. McVay, ed., North-Holland, New York, NY.

Lindsay, W. L. 1979. Chemical Equilibria in Soils. John Wiley and Sons, New York.

Marshall, W. L. 1980. "Amorphous Silica Solubilities - III. Activity Coeffi.cient Relations and Predictions of Solubility Behavior in Salt Solutions, 0 - $350^{\circ} \mathrm{C}$." Geochimica et Cosmochimica Acta, 44:925-931.

Marshall, W. L. and J. M. Warakomski. 1980. "Amorphous Silica Solubilities II. Effect of Aqueous Salt Solutions at $25^{\circ} \mathrm{C}$." Geochimica et Cosmochimica Acta, $44: 915-924$.

Materials Characterization Center (MCC). 1981. Nuclear Waste Materials Handbook. DOE/TIC 11400. Pacific Northwest Laboratory, Richland, WA.

Materials Characterization Center (MCC). 1982. Workshop on the Leaching Mechanisms of Nuclear Waste Forms, May 19-21, 1982. Summary Report. PNL-4382. Pacific Northwest Laboratory, Richland, WA.

Materials Characterization Center (MCC). 1984. Final Report of the Defense High-Level Waste Leaching Mechanisms Program. PNL-5157. Pacific Northwest Laboratory, Richland, WA.

ONWI (Office of Nuclear Waste Isolation). 1983. "Engineered Waste Package Conceptual Design: Defense High-Level Waste (Form 1), Commercial High-Level Waste (Form 1), and Spent Fuel (Form 2) Disposal in Salt." ONWI-438. Westinghouse Electric Corporation, Advanced Energy Systems Division, Pittsburgh, PA. 
Parkhurst, D. L., D. C. Thorstenson, L. N. Plummer, 1980. PHREEQE - A Computer Program for Geochemical Calculations. USGS/WRI-80-96. U.S. Geological Survey, Reston, VA.

Pederson, L. R. 1985. Radiation and Heat Damage Effects in Natural Rock Saits. PNL-5212, Pacific Northwest Laboratory, Richland, WA.

Pederson, L. R., C. Q. Buckwalter, G. L. McVay, and B. L. Riddle. 1983. Glass Surface Area to Solution Volume Ratio and Its Implications to Accelerated Leach Testing. In Scientific Basis for Nuclear Waste Management VI, D. G. Brookins, ed., North-Holland, New York, NY.

Shade, J. W., L. R. Pederson, and G. L. McVay. 1983. "Waste Glass-Metal Interactions in Brines." In Advances in Ceramics. Nuclear Waste Management, G. G. Wicks and W. A. Ross, eds. American Ceramic Society, Columbus, OH.

Soper, P. D., et al. 1983. "Optimization of Glass Composition for the Vitrification of Nuclear Waste at the Savannah River Plant." Bulletin of the American Ceramic Society, 62:1013-1018.

Strachan, 0. M. 1983. "Results from Long-Term Use of the MCC-1 Static Leach Fest Method." Nuclear and Chemical Waste Management, 4:177-188.

Strachan, D. M., K. M. Krupka, B. E. Grambow. 1984. "Solubility Interpertations of Leach Tests on Nuclear Waste Glass." Nuclear and Chemical Waste Management, 5:87-99.

Weres, 0., A. Yee, and L. Tsao. 1981. Kinetics of Silica Polymerization. J. Colloid and Interface Science 84(2):379-402. 


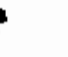

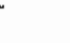


APPENDIX A 
TABLE A.1. Concentrations (mg/L) of Elements Leached from $S R L-131$ Glass in Deionized Water at $40^{\circ} \mathrm{C}$

\begin{tabular}{|c|c|c|c|c|c|c|c|c|c|c|c|c|}
\hline SAMPLE ID & $82 D-217$ & $82 D-219$ & $82 D-221$ & 82D-223 & $82 \mathrm{D}-224$ & $82 D-225$ & $82 D-247 S$ & $B 2 D-247 F$ & $82 D-248$ & $82 D-263$ & $82 D-264$ & 82D-265 \\
\hline TIME, d & 3 & 7 & 14 & 28 & 28 & 28 & 56 & 56 & 56 & 91 & 91 & 91 \\
\hline $\begin{array}{l}\mathrm{Al} \\
\mathrm{B} \\
\mathrm{Ca} \\
\mathrm{Cr} \\
\mathrm{Cs} \\
\mathrm{Cu} \\
\mathrm{Pe}\end{array}$ & $\begin{array}{l}0.020 \\
0.078 \\
0.032 \\
-0.010 \\
0.005 \\
0.002\end{array}$ & $\begin{array}{l}0.132 \\
0.276 \\
0.061 \\
0.004 \\
0.032 \\
0.003 \\
0.010\end{array}$ & $\begin{array}{l}0.287 \\
0.553 \\
0.119 \\
0.002 \\
0.069 \\
0.003 \\
0.016\end{array}$ & $\begin{array}{l}0.406 \\
0.985 \\
0.142 \\
0.001 \\
0.120 \\
0.005 \\
0.022\end{array}$ & $\begin{array}{l}0.450 \\
1.02 \\
1.49 \\
0.003 \\
0.123 \\
0.005 \\
0.023\end{array}$ & $\begin{array}{l}0.459 \\
1.09 \\
0.143 \\
0.129 \\
0.1206 \\
0.021\end{array}$ & $\begin{array}{l}0.010 \\
0.013 \\
0.006 \\
0.001 \\
-0.009 \\
0.009\end{array}$ & $\begin{array}{l}0.406 \\
1.42 \\
0.074 \\
0.002 \\
0.166 \\
0.002 \\
0.003\end{array}$ & $\begin{array}{l}0.58 \mathrm{~B} \\
1.57 \\
0.165 \\
0.001 \\
0.216 \\
0.005 \\
0.033\end{array}$ & $\begin{array}{l}0.619 \\
1.74 \\
0.182 \\
0.001 \\
0.210 \\
0.003 \\
0.034\end{array}$ & $\begin{array}{l}0.63 \\
1.78 \\
0.159 \\
-0.215 \\
0.001 \\
0.031\end{array}$ & $\begin{array}{l}0.660 \\
1.89 \\
0.185 \\
-- \\
0.220 \\
-- \\
0.029\end{array}$ \\
\hline $\mathrm{K}$ & -- & -- & $\ldots$ & -- & -- & -- & -- & -- & -- & -- & $-\infty$ & $\ldots$ \\
\hline La & -- & -- & - & - & -- & $-n$ & 0.003 & -- & -- & 0.003 & -- & -- \\
\hline $\begin{array}{l}\mathrm{Li} \\
\mathrm{Mg} \\
\mathrm{Mn} \\
\mathrm{Mo} \\
\mathrm{Na}\end{array}$ & $\begin{array}{l}0.043 \\
0.007 \\
0.041 \\
0.001 \\
0.299\end{array}$ & $\begin{array}{l}0.168 \\
0.047 \\
0.051 \\
-- \\
1.02\end{array}$ & $\begin{array}{l}0.311 \\
0.141 \\
0.018 \\
0.002 \\
2.02\end{array}$ & $\begin{array}{l}0.592 \\
0.197 \\
0.028 \\
-- \\
3.26\end{array}$ & $\begin{array}{l}0.618 \\
0.195 \\
0.025 \\
3.37\end{array}$ & $\begin{array}{l}0.654 \\
0.219 \\
0.029 \\
0.002 \\
3.68\end{array}$ & $\begin{array}{l}0.007 \\
0.041 \\
0.052 \\
0.002 \\
-\end{array}$ & $\begin{array}{l}0.816 \\
0.105 \\
0.001 \\
0.001 \\
4.69\end{array}$ & $\begin{array}{l}0.959 \\
0.309 \\
0.049 \\
0.001 \\
5.61\end{array}$ & $\begin{array}{l}1.11 \\
0.255 \\
0.061 \\
-5.98\end{array}$ & $\begin{array}{l}1.12 \\
0.240 \\
0.051 \\
-- \\
6.04\end{array}$ & $\begin{array}{l}1.17 \\
0.257 \\
0.037 \\
-- \\
6.26\end{array}$ \\
\hline $\begin{array}{l}\text { Na } \\
\text { Nd }\end{array}$ & 0.299 & 1.02 & $\begin{array}{l}2.02 \\
0.001\end{array}$ & $\begin{array}{l}3.26 \\
--\end{array}$ & $\begin{array}{l}3.31 \\
--\end{array}$ & $\begin{array}{c}3.08 \\
-0\end{array}$ & $=$ & $\begin{array}{l}4.69 \\
--\end{array}$ & $\begin{array}{l}5.61 \\
--\end{array}$ & $\begin{array}{l}5.98 \\
--\end{array}$ & $\begin{array}{l}6.04 \\
--\end{array}$ & 6.26 \\
\hline $\begin{array}{l}\text { Ni } \\
\text { P } \\
\text { Si } \\
\text { Sr }\end{array}$ & $\begin{array}{l}0.014 \\
-- \\
0.490 \\
0.003\end{array}$ & $\begin{array}{l}0.010 \\
-1.61 \\
0.009\end{array}$ & $\begin{array}{l}0.006 \\
3.04 \\
0.016\end{array}$ & $\begin{array}{l}0.014 \\
0.060 \\
5.15 \\
0.020\end{array}$ & $\begin{array}{l}0.011 \\
0.054 \\
5.39 \\
0.021\end{array}$ & $\begin{array}{l}0.017 \\
0.055 \\
5.61 \\
0.019\end{array}$ & $\begin{array}{l}0.025 \\
-- \\
0.084 \\
0.002\end{array}$ & $\begin{array}{l}0.002 \\
0.025 \\
7.14 \\
0.009\end{array}$ & $\begin{array}{l}0.020 \\
-- \\
7.93 \\
0.022\end{array}$ & $\begin{array}{l}0.030 \\
0.053 \\
0.68 \\
0.017\end{array}$ & $\begin{array}{l}0.023 \\
0.051 \\
0.81 \\
0.016\end{array}$ & $\begin{array}{l}0.020 \\
0.020 \\
9.27 \\
0.017\end{array}$ \\
\hline Ti & -- & $\ldots$ & 0.002 & - & -- & -- & $=$ & $=$ & -- & -- & -- & - \\
\hline $\begin{array}{l}\mathrm{U} \\
\mathrm{zn} \\
\mathrm{zr}\end{array}$ & $\begin{array}{l}0.015 \\
0.003 \\
0.002\end{array}$ & $\begin{array}{l}0.017 \\
0.002 \\
\ldots\end{array}$ & $\begin{array}{l}0.021 \\
0.005 \\
0.003\end{array}$ & $\begin{array}{l}0.034 \\
0.002 \\
0.003\end{array}$ & $\begin{array}{l}0.035 \\
0.003 \\
--\end{array}$ & $\begin{array}{l}0.033 \\
0.004 \\
--\end{array}$ & $\begin{array}{l}0.005 \\
0.005 \\
0.001\end{array}$ & $\begin{array}{l}0.046 \\
0.050 \\
0.001\end{array}$ & $\begin{array}{l}0.083 \\
0.001 \\
--\end{array}$ & $\begin{array}{l}0.092 \\
0.003 \\
--\end{array}$ & $\begin{array}{l}0.083 \\
0.003 \\
--\end{array}$ & $\begin{array}{l}0.102 \\
0.003 \\
--\end{array}$ \\
\hline DH & 7.44 & 8.59 & $\theta . \theta 2$ & 9.13 & 9.14 & 9.19 & 9.33 & 9.33 & 8.77 & 8.68 & 9.18 & 9.27 \\
\hline
\end{tabular}

$S=$ results from acid stripping the leach container

$F$ - results from solutions flltered through an $18 \AA$ fllter. Note ca data are usually high in these solutions and should be disregarded. 
TABLE A.1. (contd)

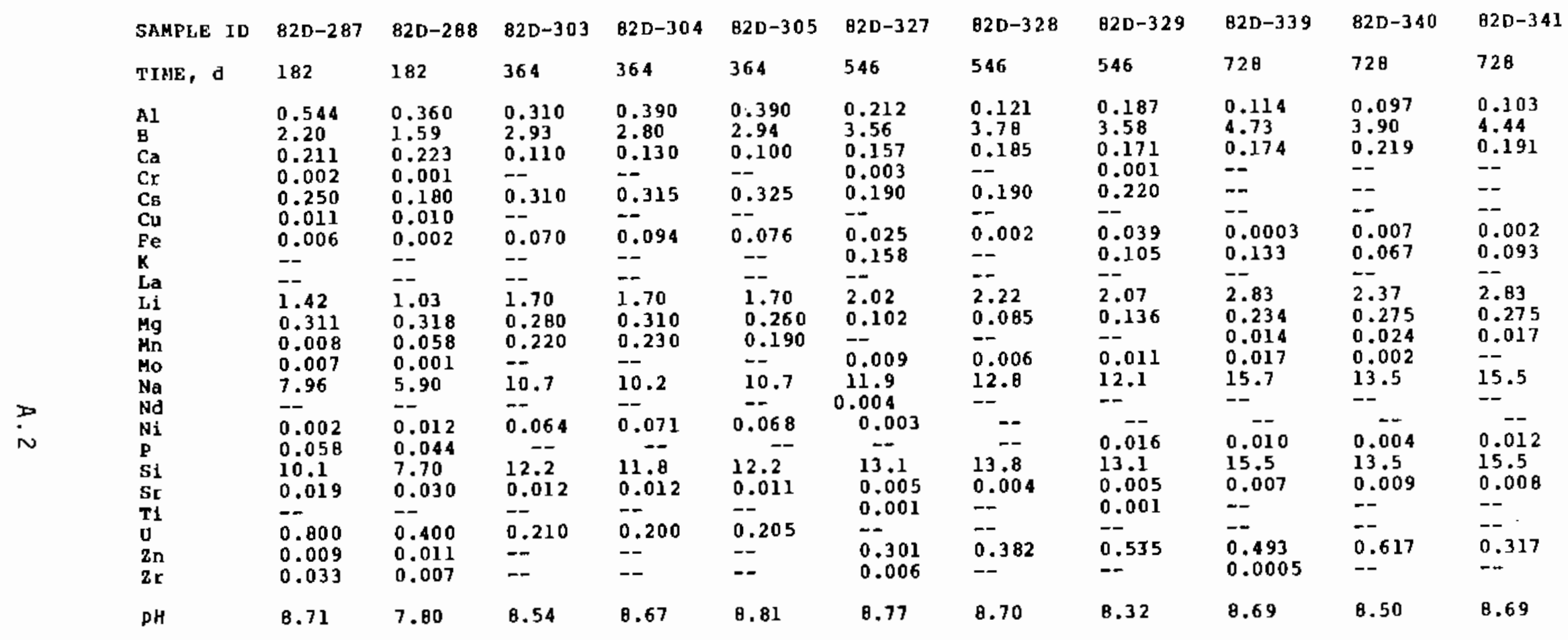

$S=$ results from acid stripping the leach container

$F=$ results from solutions flltered through an $18 \AA^{\circ}$ fllter. Hote Ca data are usually high in these solutions and should be disregarded. 
TABLE A.2. Normalized Elemental Mass Loss $\left(g / \mathrm{m}^{2}\right)$ for SRL-131 Giass in Deionized Water at $40^{\circ} \mathrm{C}$

\begin{tabular}{|c|c|c|c|c|c|c|c|c|c|c|c|c|}
\hline SAMPLE ID & $82 D-217$ & $82 D-219$ & $82 D-221$ & $82 D-223$ & e2D-224 & $82 D-225$ & $82 \mathrm{D}-247 \mathrm{~F}$ & $82 D-248$ & $82 D-263$ & $82 D-264$ & $82 D-265$ & $82 D-287$ \\
\hline Time, a & 3 & 7 & 14 & 28 & 28 & 28 & 56 & 56 & 91 & 91 & 91 & 182 \\
\hline $\begin{array}{l}\text { Al } \\
\text { B }\end{array}$ & $\begin{array}{l}0.12 \\
0.25\end{array}$ & $\begin{array}{l}0.02 \\
0.89\end{array}$ & $\begin{array}{l}1.78 \\
1.8\end{array}$ & $\begin{array}{l}2.52 \\
3.21\end{array}$ & $\begin{array}{l}2.79 \\
3.32\end{array}$ & $\begin{array}{l}2.84 \\
3.55\end{array}$ & $\begin{array}{l}2.52 \\
4.63\end{array}$ & $\begin{array}{l}3.64 \\
5.12\end{array}$ & $\begin{array}{l}3.83 \\
5.68\end{array}$ & $\begin{array}{l}3.9 \\
5.81\end{array}$ & $\begin{array}{l}4.09 \\
6.17\end{array}$ & $\begin{array}{l}3.37 \\
7.18\end{array}$ \\
\hline $\mathrm{Ca}$ & 0.43 & 0.82 & 1.6 & 1.91 & 20 & 1.92 & & 2.22 & 2.39 & 2.08 & 2.43 & 2.78 \\
\hline Cr & -- & -- & - & - & -- & $-\infty$ & - & -- & 0.048 & -- & -- & 0.14 \\
\hline $\mathrm{Cs}$ & 0.35 & 1.13 & 2.44 & 4.24 & 4.35 & 4.56 & 5.87 & 7.63 & 7.42 & 7.6 & 7.77 & 0.83 \\
\hline $\mathrm{Cu}$ & -- & $-\infty$ & -- & -- & $=$ & 0.21 & -- & $-\infty$ & 1.04 & 0.21 & -- & 4.38 \\
\hline $\mathrm{Fe}$ & - & 0.008 & 0.014 & 0.02 & 0.021 & 0.019 & 0.001 & 0.031 & 0.033 & 0.03 & 0.028 & 0.005 \\
\hline $\mathbf{R}$ & -- & - & -- & -- & - & -- & -- & -- & $m$ & -- & -- & -- \\
\hline La & -- & -- & - & -- & -- & - & -- & -- & 0.11 & -- & $=$ & -- \\
\hline $\begin{array}{l}\mathrm{LI} \\
\mathrm{Mg} \\
\mathrm{Mn}\end{array}$ & $\begin{array}{l}0.22 \\
0.094 \\
0.15\end{array}$ & $\begin{array}{l}0.92 \\
0.63 \\
0.19\end{array}$ & $\begin{array}{l}1.71 \\
1.89 \\
0.063\end{array}$ & $\begin{array}{l}3.27 \\
2.63 \\
0.1\end{array}$ & $\begin{array}{l}3.42 \\
2.61 \\
0.089\end{array}$ & $\begin{array}{l}3.62 \\
2.93 \\
0.1\end{array}$ & $\begin{array}{l}4.51 \\
1.4 \\
--\end{array}$ & $\begin{array}{l}5.31 \\
4.13 \\
0.18\end{array}$ & $\begin{array}{l}6.16 \\
3.29 \\
0.23\end{array}$ & $\begin{array}{l}6.21 \\
3.09 \\
0.19\end{array}$ & $\begin{array}{l}6.49 \\
3.32 \\
0.14\end{array}$ & $\begin{array}{l}7.88 \\
4.04 \\
0.03\end{array}$ \\
\hline Mo & -- & -- & -- & $\because 1$ & -0 & $\ldots$ & -- & -- & -- & -- & 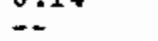 & -0 \\
\hline $\mathrm{Na}$ & 0.27 & 0.93 & 1.84 & 2.97 & 3.07 & 3.36 & $4.2 \theta$ & 5.12 & 5.45 & 5.51 & 5.71 & 7.26 \\
\hline Nd & $-\infty$ & -- & 0.026 & $=$ & -- & - & $=$ & -- & -- & -- & -- & -- \\
\hline $\mathrm{Ni}$ & 0.11 & 0.074 & 0.041 & 0.11 & 0.083 & 0.13 & 0.0083 & 0.16 & 0.25 & 0.19 & 0.17 & 0.017 \\
\hline $\mathrm{P}$ & $=$ & $\ldots$ & -- & 3.21 & 1.83 & 2.06 & -- & $-\infty$ & 5.73 & 5.28 & -- & 6.88 \\
\hline $5 i$ & 0.27 & 0.89 & 1.68 & 2.85 & 2.98 & 3.1 & 3.95 & 4.39 & 4.8 & 4.87 & 5.12 & 5.58 \\
\hline sr & 0.25 & 0.76 & 1.35 & 1.69 & 1.77 & 1.6 & 0.76 & 1.86 & 1.44 & 1.35 & 1.44 & 1.6 \\
\hline Ti & -- & -- & 0.044 & -- & -- & -- & -- & -- & -- & -- & -- & -- \\
\hline $\mathrm{U}$ & 0.1 & 0.12 & 0.15 & 0.24 & 0.24 & 0.23 & 0.32 & $0.5 \theta$ & 0.64 & 0.58 & 0.71 & 5.6 \\
\hline $\mathrm{zn}$ & -- & -- & - & -- & -- & $\cdots$ & -- & -- & -- & - & -- & -- \\
\hline 25 & 0.087 & -- & 0.13 & 0.13 & -- & -- & 0.044 & -- & $-\cdots$ & -- & -- & 1.44 \\
\hline
\end{tabular}

\footnotetext{
= results from acid stripping the leach contalner

$F=$ results from solutions filtered through an $18 \AA$ filter. Wote Ca data
} are usually high in these solutions and should be disregarded. 
TABLE A.2. (contd)

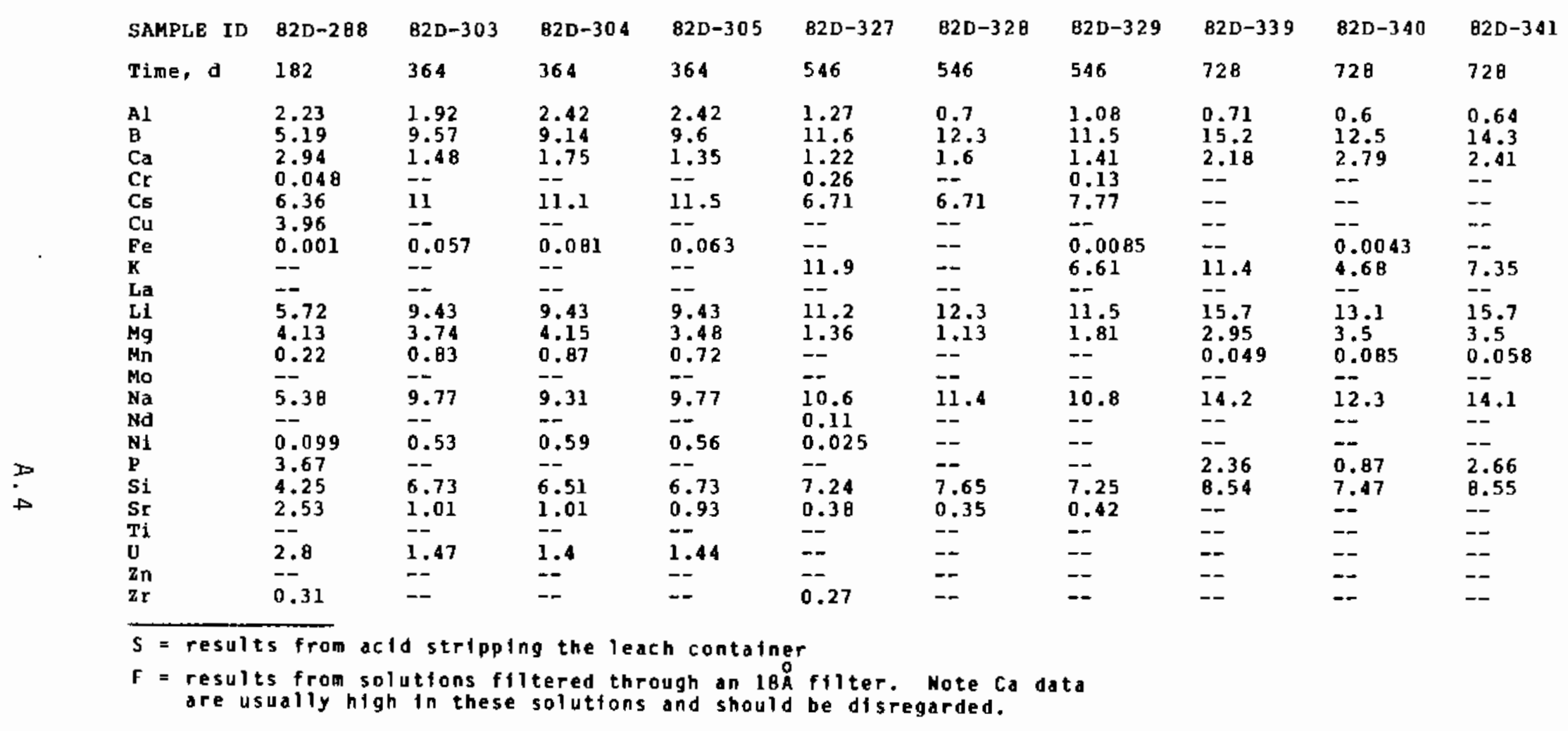


TABLE A.3. Concentrations (mg/L) of Elements Leached from SRL-131 Glass in Deionized Water at $90^{\circ} \mathrm{C}$

\begin{tabular}{|c|c|c|c|c|c|c|c|c|c|c|c|c|}
\hline & $82 D-218$ & $82 \mathrm{D}-220$ & $82 \mathrm{D}-222$ & $82 D-235$ & B2D -236 & $82 \mathrm{D}-237$ & $B 2 D-255 F$ & $82 \mathrm{D}-255 \mathrm{~s}$ & $82 D-256$ & 62D-275 & $82 D-276$ & B2D -277 \\
\hline TIME, d & 3 & 7 & 14 & 28 & 28 & 28 & 56 & 56 & 56 & 91 & 91 & 91 \\
\hline $\begin{array}{l}\text { Al } \\
\text { B }\end{array}$ & $\begin{array}{l}1.48 \\
4.14\end{array}$ & $\begin{array}{l}1.8 B \\
6.23\end{array}$ & $\begin{array}{l}2.04 \\
7.97\end{array}$ & $\begin{array}{l}2.27 \\
10.3\end{array}$ & $\begin{array}{l}2.26 \\
10.2\end{array}$ & $\begin{array}{l}2.22 \\
9.92\end{array}$ & $\begin{array}{l}2.52 \\
15.2\end{array}$ & 0.030 & $\begin{array}{l}2.65 \\
15.7\end{array}$ & $\begin{array}{l}2.60 \\
19.7\end{array}$ & $\begin{array}{l}2.64 \\
19.9\end{array}$ & $\begin{array}{l}2.50 \\
21.1\end{array}$ \\
\hline $\begin{array}{l}\mathrm{Ca} \\
\mathrm{Cr}\end{array}$ & $\begin{array}{l}0.061 \\
--\end{array}$ & 0.024 & ${ }_{--}^{0.031}$ & $=$ & 0.012 & 0.011 & $\begin{array}{l}-- \\
--\end{array}$ & $=$ & $\begin{array}{l}0.014 \\
--\end{array}$ & 0.013 & $=-$ & 0.013 \\
\hline $\mathrm{Cs}_{\mathrm{C}}$ & 0.431 & 0.682 & 0.880 & 1.04 & 1.02 & 1.00 & 1.03 & -- & 1.14 & 1.09 & 1.05 & 1.06 \\
\hline $\mathrm{Cu}$ & 0.020 & 0.005 & - & -- & 0.004 & - & - & 0.006 & - & - & 0.004 & 0.006 \\
\hline $\mathbf{F e}$ & 0.039 & 0.017 & 0.028 & 0.044 & 0.042 & 0.101 & 0.012 & 0.015 & 0.176 & 0.064 & 0.111 & $0.12 B$ \\
\hline $\mathrm{K}$ & -- & -- & -- & -- & -- & -7 & -- & - & & -- & - & -- \\
\hline La & -- & -- & -- & -- & $=$ & $0.00 B$ & -- & -- & 0.036 & -- & $=$ & $-\overline{1} 200$ \\
\hline $\mathbf{L i}$ & 2.54 & 3.88 & 4.91 & 6.23 & 6.19 & 5.94 & 9.10 & 0.020 & 9.49 & 12.8 & 13.1 & 13.300 \\
\hline $\begin{array}{l}\mathrm{Hg} \\
\mathrm{Hn}\end{array}$ & 0.014 & 0.023 & 0.030 & 0.039 & 0.052 & 0.057 & 0.002 & 0.033 & $\begin{array}{l}0.129 \\
0.075\end{array}$ & $\overline{0.048}$ & $\overline{0.046}$ & 0.073 \\
\hline Mo & 0.018 & -- & -- & - & & $=$ & -- & $\approx$ & 0.012 & -- & $\cdots$ & -- \\
\hline $\mathrm{Na}$ & 15.2 & 21.0 & 30.0 & 34.3 & 34.1 & 32.9 & 51.4 & -- & 54.5 & 63.4 & 64.3 & 64.5 \\
\hline $\mathrm{Nd}$ & -- & -- & -- & $=$ & -- & $=$ & -- & $=$ & $-\overline{0} 023$ & -- & - & $=-030$ \\
\hline $\mathbf{N i}$ & -- & $\cdots$ & -- & -- & $=$ & -- & $\cdots$ & -- & 0.023 & $=$ & 0.024 & 0.020 \\
\hline$\stackrel{P}{S i}$ & 20.2 & 29.3 & 36.4 & $\overline{44} \cdot B$ & 44.6 & $\overline{42.5}$ & 60.7 & $\overline{0.145}$ & 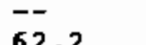 & 71 & $\overline{71} 7$ & $\overline{73} .0$ \\
\hline Sr & 0.018 & 0.002 & -- & $=-$ & $=-$ & -.. & - & $\ldots$ & 0.016 & -- & $\ldots$ & 13.0 \\
\hline & 0.007 & 0.002 & 0.002 & -- & -- & 0.007 & -- & -- & 0.012 & 0.003 & 0.003 & 0.014 \\
\hline $\mathrm{U}$ & 0.163 & 0.152 & 0.222 & 0.113 & 0.236 & 0.236 & 0.233 & 0.008 & 0.382 & 0.567 & 0.355 & 0.507 \\
\hline $\mathrm{Zn}_{\mathrm{I}}$ & 0.033 & -- & - & -- & $\overline{-}$ & $=$ & 0.061 & - & 0.014 & - & - & 0.015 \\
\hline pH & 10.0 & 10.11 & 10.19 & 10.13 & 10.13 & 10.04 & 9.92 & 9.92 & 10.15 & 10.24 & 10.24 & 10.08 \\
\hline
\end{tabular}

$S=$ results from acid stripping the leach container

$F=$ results from solutions filtered through an $18 \AA$ f 11 ter. Note Ca data are usually high in these solutions and should be disregarded. 
TABLE A.3. (contd)

\begin{tabular}{|c|c|c|c|c|c|c|c|c|c|c|c|c|}
\hline & $82 D-295$ & $82 \mathrm{D}-295 \mathrm{~F}$ & $82 D-2958$ & $B 2 D-296$ & $82 D-2965$ & 82D-315 & $82 \mathrm{D}-315 \mathrm{~F}$ & $82 D-315 S$ & $82 D-316$ & $82 D-316 F$ & $82 D-3165$ & $82 D-317$ \\
\hline TIME, $\mathrm{d}$ & 182 & 182 & 182 & 182 & 182 & 364 & 364 & 364 & 364 & 364 & 364 & 364 \\
\hline Al & 2.48 & 2.55 & & 2.41 & 0.032 & 2,30 & 2.30 & - & 2.20 & 2.20 & -- & 2.10 \\
\hline $\begin{array}{l}\mathrm{B} \\
\mathrm{Ca}\end{array}$ & $\begin{array}{l}28.4 \\
0.019\end{array}$ & $\begin{array}{l}28.4 \\
0.138\end{array}$ & 0.442 & $\begin{array}{l}27.6 \\
0.017\end{array}$ & 0.536 & 38.5 & 38.1 & $=-$ & 41.6 & 41.5 & $=$ & 40.4 \\
\hline $\mathrm{Cr}$ & 0.024 & 0.021 & - & 0.026 & - & 0.053 & 0.048 & -- & 0.059 & $\begin{array}{l}0.170 \\
0.058\end{array}$ & $=-$ & $\overline{0.053}$ \\
\hline $\mathrm{Cs}$ & 0.960 & 1.00 & 0.011 & 1.10 & 0.017 & 1.10 & 1.10 & -- & 1.10 & 1.10 & - & 1.10 \\
\hline $\mathrm{Cu}$ & 0.009 & -- & & 0.009 & & $-\pi$ & -- & -- & & & $\ldots$ & \\
\hline $\mathbf{F e}$ & 0.115 & 0.025 & 0.010 & 0.109 & 0.008 & 0.097 & 0.027 & 0.021 & 0.100 & 0.028 & 0.015 & 0.057 \\
\hline K & $=--$ & -- & -- & $\because$ & $\cdots$ & 0.350 & 0.400 & -- & 0.400 & 0.380 & -- & 0.350 \\
\hline La & $\overline{16.7}$ & $\overline{10} 5$ & $\overline{0.237}$ & $\ddot{16}$, & 0.281 & 20 & $\overline{20} 0$ & $=$ & $\overline{1} 0$ & $=$ & -- & 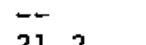 \\
\hline $\mathrm{Mg}$ & -- & -- & -- & 20.2 & -- & -- & -- & -- & --0 & --.7 & -- & --.2 \\
\hline$M n$ & 0.045 & -- & 0.009 & 0.027 & 0.010 & 0.044 & -- & 0.017 & 0.043 & -- & 0.010 & 0.032 \\
\hline Mo & 85.3 & $\overline{94.6}$ & $\overline{1.35}$ & $\overline{A 4} 6$ & $i_{63}$ & $\overline{123}$ & $-\overline{121}$ & $=-$ & $-\overline{13}$ & $-\overline{30}$ & & $-\overline{-}$ \\
\hline $\mathrm{Na}$ & -- & -2 & -- & $\ldots$ & -- & -- & -- & -- & -- & -- & - & -2 \\
\hline N1 & - & 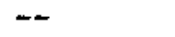 & -- & 0.022 & -- & 0.028 & -- & -- & 0.020 & -- & -- & 0.023 \\
\hline P & $\overline{0} 7$ & $\overline{-}$ & -- & $\overline{-1} 7$ & 39 & $\overline{134}$ & $\overline{123}$ & חונים & $-\overline{3}$ & $\cdots$ & - & 129 \\
\hline Sr & -91. & -9.1 & $\begin{array}{l}1.44 \\
0.003\end{array}$ & $=-1$ & --01 & 124 & -- & -- & 131 & 130 & 0.100 & 129 \\
\hline $\mathbf{T i}$ & -- & -- & -- & -- & -- & -- & -- & -- & -- & -- & -- & -- \\
\hline $\mathrm{u}$ & 2.62 & -- & -- & 0.540 & - & 0.714 & 0.461 & 0.001 & 0.750 & 0.545 & 0.001 & 0.650 \\
\hline Zn & -- & 0.611 & -- & -- & -- & 0.012 & 0.750 & -- & -- & 0.830 & -- & \\
\hline $2 \mathbf{t}$ & 0.013 & & -- & -- & -- & & $\cdots$ & $\cdots$ & -- & & -- & -- \\
\hline pH & 10.27 & 10.27 & 10.27 & 10.21 & 10.21 & 9.98 & 9.98 & 9.98 & 10.0 & 10.0 & 10.0 & 9.99 \\
\hline
\end{tabular}

5 = results from acid stripping the leach contalner

$F$ = results from solutions flltered through an $18 \AA$ fllter. Note Ca data are usually high in these solutions and should be disregarded. 
TABLE A.3. (contd)

\begin{tabular}{|c|c|c|c|c|c|c|c|c|}
\hline & $82 D-317 F$ & $82 D-317 s$ & $82 D-333$ & $82 D-334$ & $82 D-335$ & $82 D-345$ & $82 D-346$ & $82 D-347$ \\
\hline TIME, $\mathrm{d}$ & 364 & 364 & 546 & 546 & 546 & 728 & $72 B$ & 728 \\
\hline $\begin{array}{l}\mathrm{Al} \\
\mathrm{B} \\
\mathrm{Ca} \\
\mathrm{Cr} \\
\mathrm{Cs}\end{array}$ & $\begin{array}{l}2.10 \\
40.3 \\
0.160 \\
0.055 \\
1.00\end{array}$ & $\begin{array}{l}-- \\
-- \\
-- \\
--\end{array}$ & $\begin{array}{l}2.32 \\
35.9 \\
0.242 \\
0.042 \\
0.700\end{array}$ & $\begin{array}{l}2.30 \\
33.3 \\
0.253 \\
0.044 \\
0.520\end{array}$ & $\begin{array}{l}2.60 \\
35.7 \\
0.256 \\
0.050 \\
0.680\end{array}$ & $\begin{array}{l}2.52 \\
35.2 \\
0.182 \\
0.057 \\
1.04\end{array}$ & $\begin{array}{l}2.00 \\
41.1 \\
0.212 \\
0.065 \\
1.10\end{array}$ & $\begin{array}{l}2.29 \\
38.9 \\
0.193 \\
0.059 \\
1.10\end{array}$ \\
\hline $\mathrm{Cu}$ & -- & -- & -- & $=-$ & -- & $=-$ & -- & $=$ \\
\hline $\mathbf{F e}$ & $\begin{array}{l}0.065 \\
0.430\end{array}$ & 0.020 & $\begin{array}{l}0.014 \\
0.263\end{array}$ & $\begin{array}{l}0.077 \\
0.263\end{array}$ & $\begin{array}{l}0.041 \\
0.290\end{array}$ & $\begin{array}{l}0.017 \\
0.346\end{array}$ & $\begin{array}{l}0.002 \\
0.386\end{array}$ & $\begin{array}{l}0.012 \\
0.373\end{array}$ \\
\hline $\mathrm{La}$ & -- & -- & -- & $=$ & -- & 0.0006 & -- & -- \\
\hline Li & 21.0 & -- & 19.6 & 17.9 & 19.1 & 19.8 & 23.1 & 21.6 \\
\hline Mg & -- & - & -- & -- & -- & 0.031 & -- & 0.021 \\
\hline $\operatorname{Mn}$ & -- & 0.022 & -- & -- & $=-$ & 0.002 & 0.0005 & 0.0005 \\
\hline Ho & -- & -- & 0.013 & 0.019 & 0.009 & 0.009 & 0.018 & 0.021 \\
\hline Na & 125 & -- & 106 & 100 & 108 & 113 & 128 & 123 \\
\hline Nd & -- & -- & $=$ & -- & -- & -- & -- & -- \\
\hline N1 & -- & - & -- & -- & -- & -- & -- & -- \\
\hline $\mathbf{P}$ & -- & -- & 0.449 & 0.399 & 0.449 & 0.395 & 0.411 & 0.865 \\
\hline Si & 128 & 0.120 & 113 & 105 & 110 & 107 & 120 & 115 \\
\hline Sr & -- & -- & 0.0002 & -- & 0.002 & 0.002 & 0.001 & 0.001 \\
\hline $\mathbf{T} \mathbf{i}$ & -- & -- & -- & -- & 0.011 & 0.005 & -- & $-\infty$ \\
\hline v & 0.434 & 0.002 & -- & -- & $\cdots$ & -- & -- & -- \\
\hline $\mathrm{zn}$ & 1.00 & -- & 1.73 & 1.88 & 1.23 & 0.925 & 1.14 & 0.909 \\
\hline $\mathbf{Z I}$ & -- & -- & 0.002 & -- & 0.018 & 0.015 & -- & 0.003 \\
\hline pH & 9.99 & 9.99 & 9.97 & 10.01 & 10.01 & 9.83 & 9.89 & 9.86 \\
\hline
\end{tabular}

$S=$ results from acid stripping the leach container

$F=$ results from solutions flltered through an $18 \mathrm{~A}$ fliter. Note Ca data are usualiy high in these solutions and should be disregarded. 
TABLE A.4. Normalized Elemental Mass Loss $\left(\mathrm{g} / \mathrm{m}^{2}\right)$ for SRL-131 GIass in Deionized Water at $90^{\circ} \mathrm{C}$

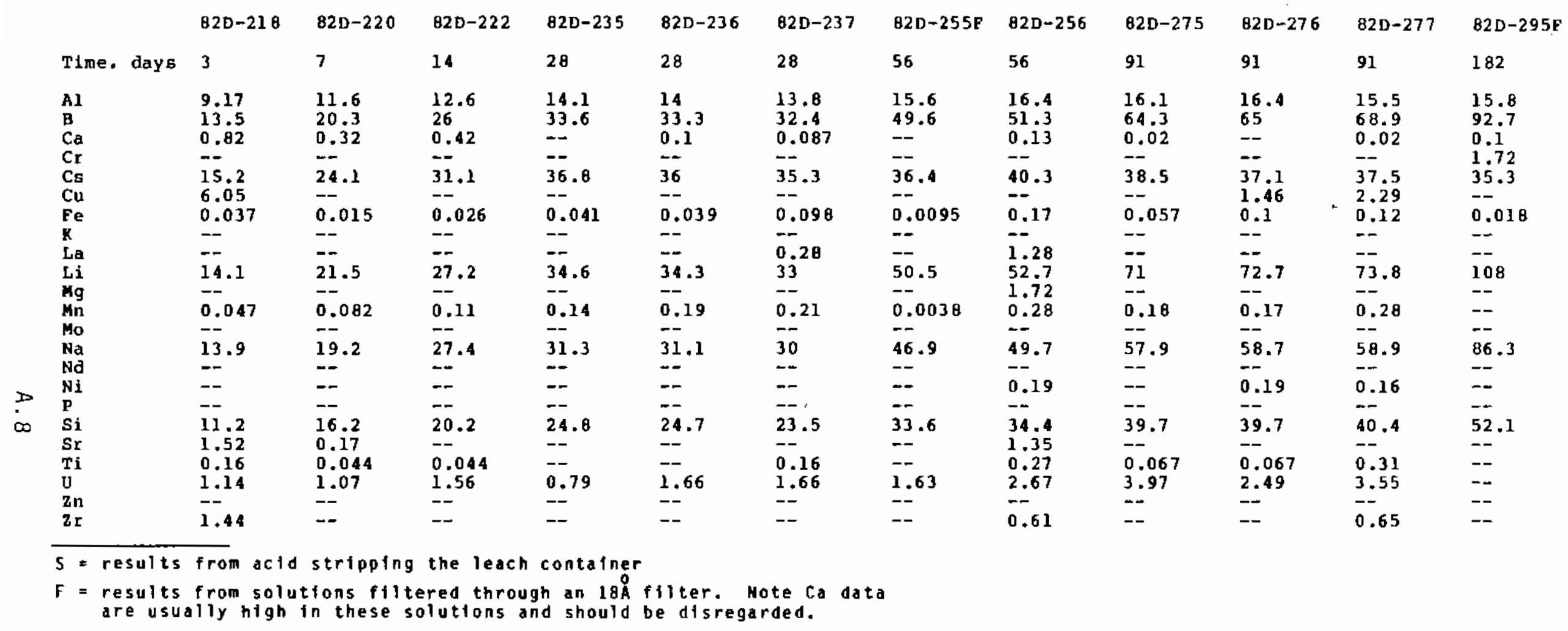


TABLE A.4. (contd)

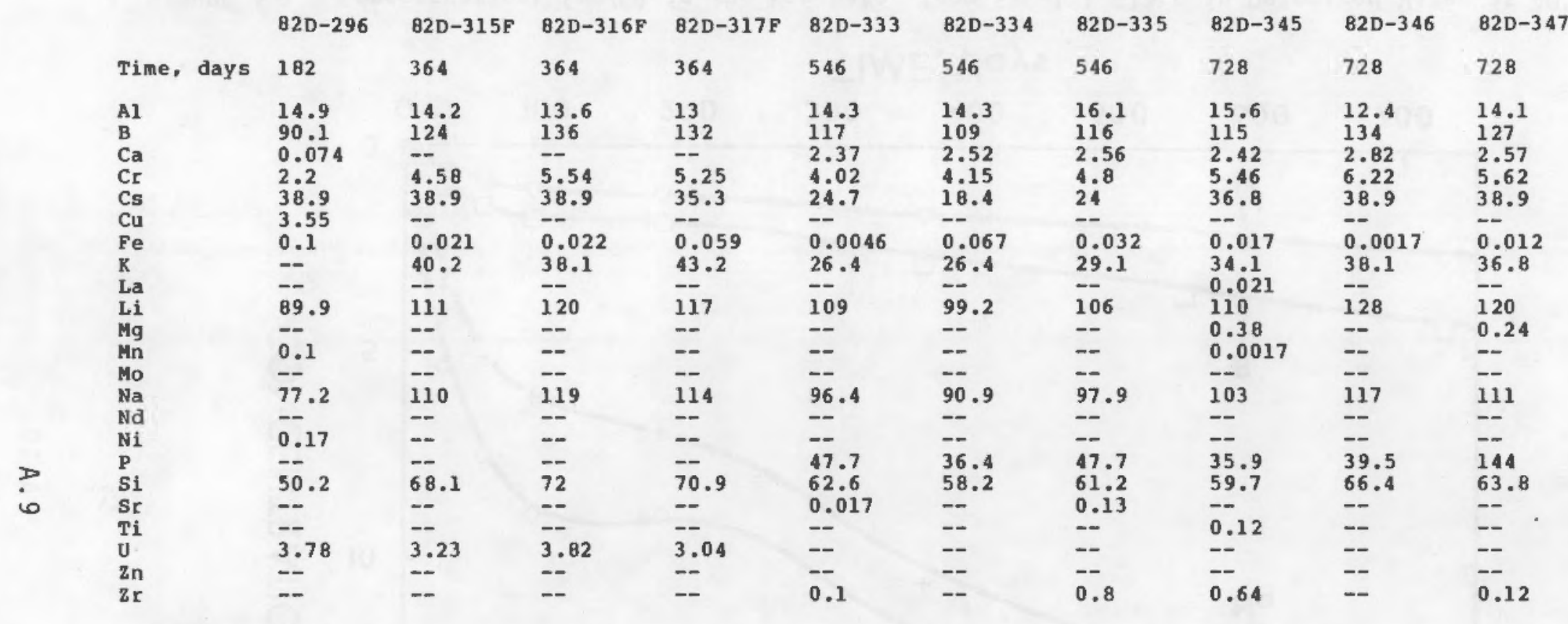

$S=$ results from acid stripping the leach container

$F=$ results from solutions filtered through an $18 \AA$ filter. Note Ca data are usually high in these solutions and should be disregarded. 


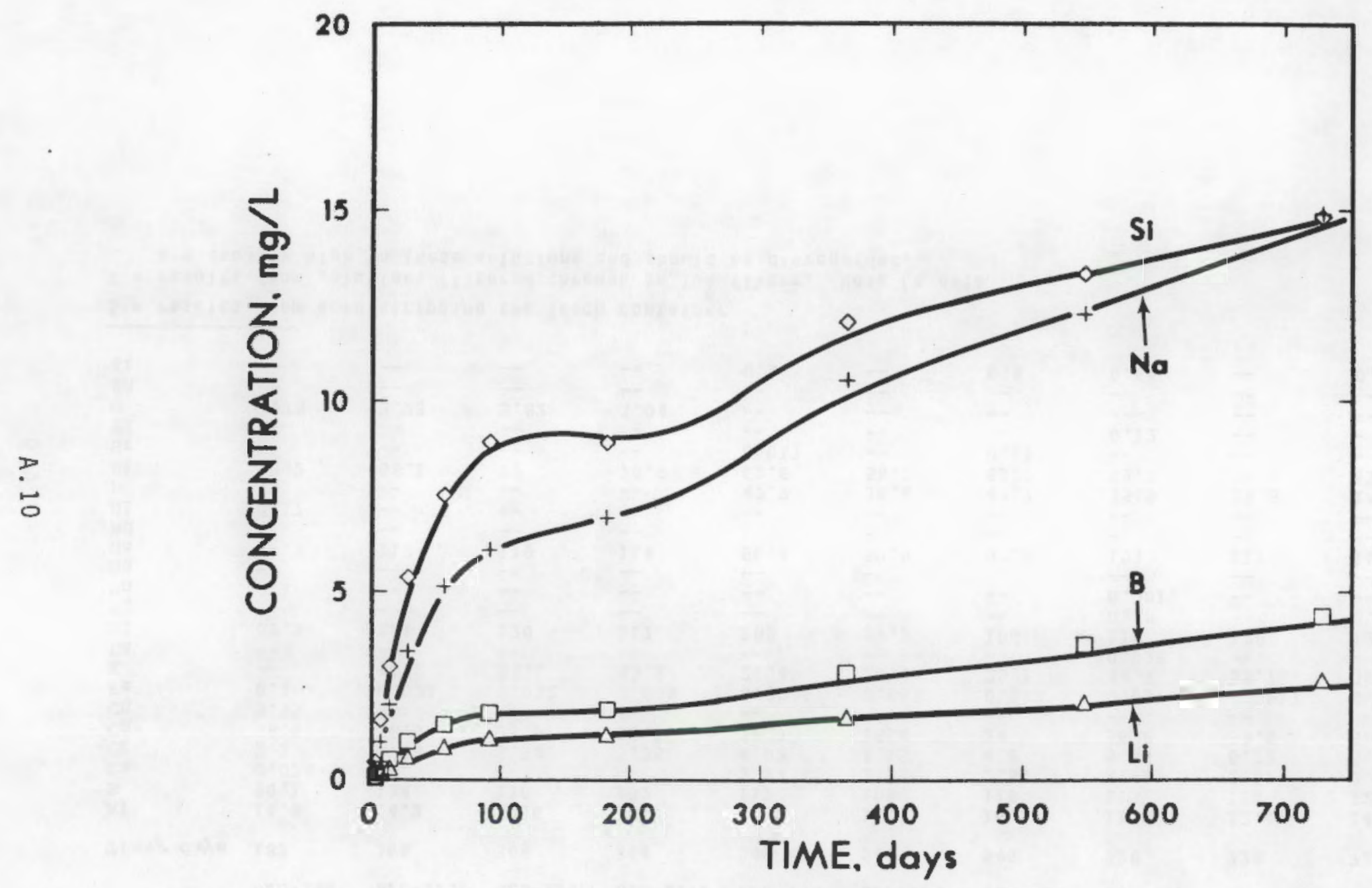

FIGURE A.1. Concentrations $(\mathrm{mg} / \mathrm{L})$ in the Leachates from SRL-131 Glass in Deionized Water at $40^{\circ} \mathrm{C}$ 


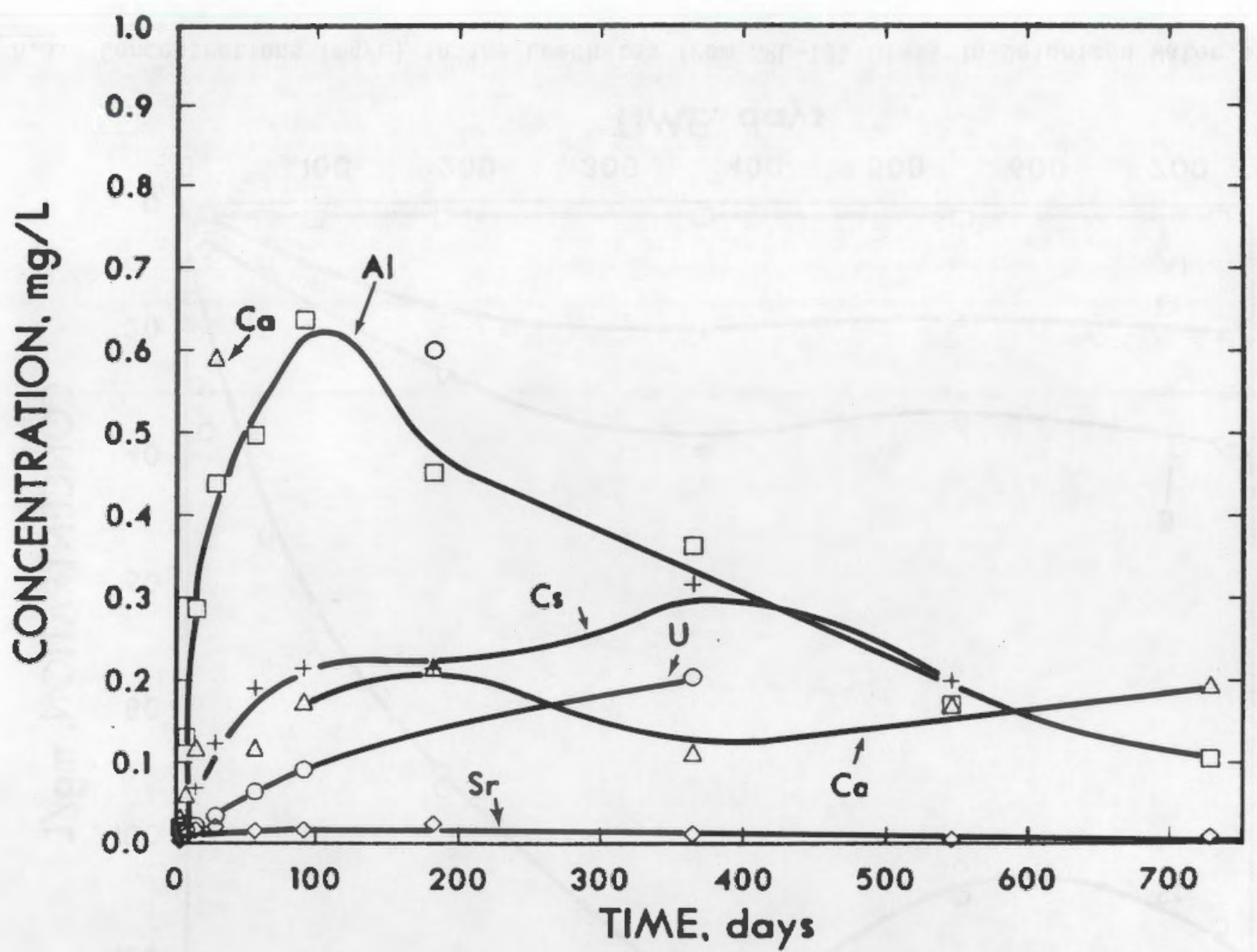

FIGURE A.2. Concentrations $\left(\mathrm{mg} / \mathrm{L}\right.$ ) in the Leachates from SRL-131 Glass in Deionized Water at $40^{\circ} \mathrm{C}$ 


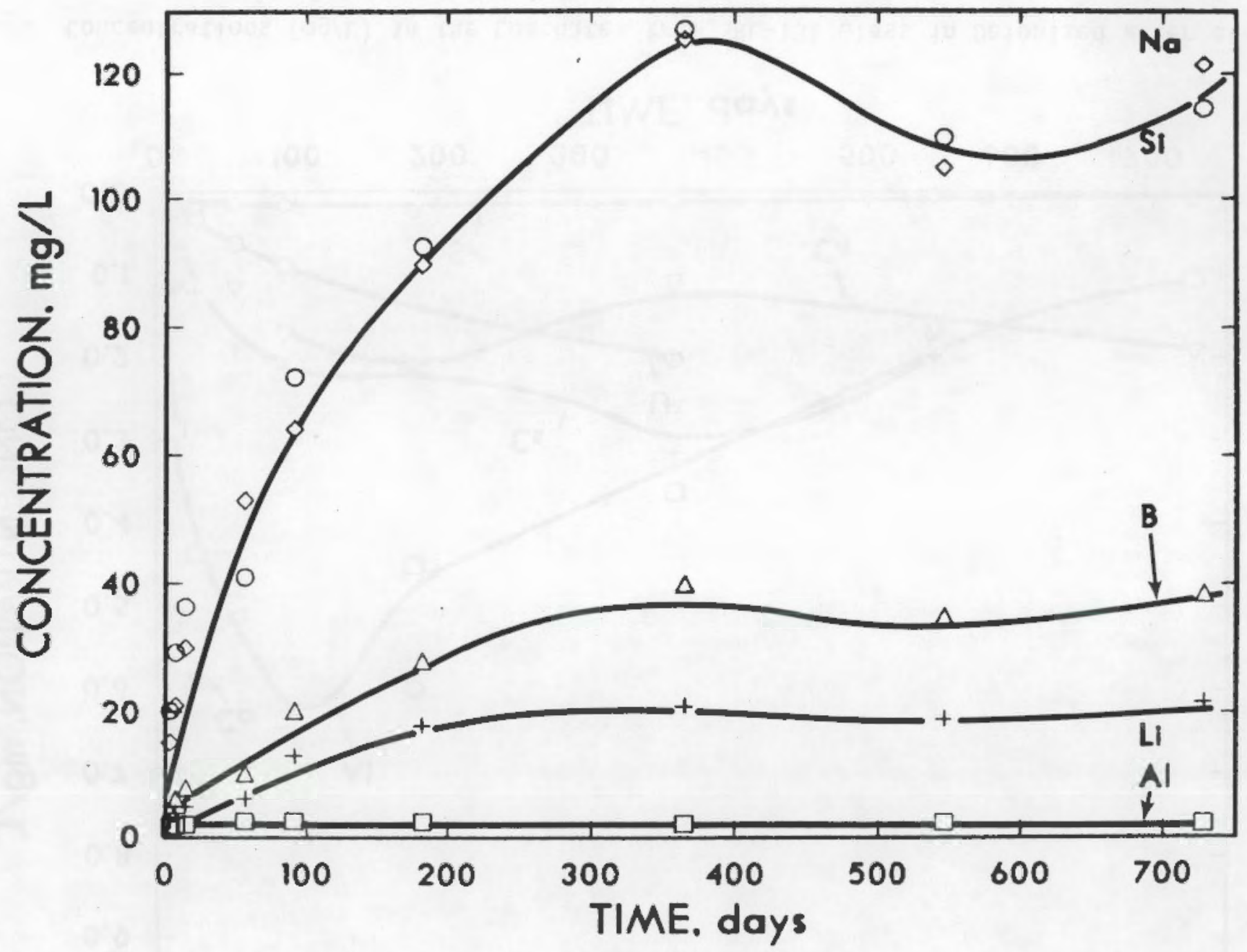

FIGURE A.3. Concentrations $(\mathrm{mg} / \mathrm{L})$ in the Leachates from SRL-131 Glass in Deionized Water at $90^{\circ} \mathrm{C}$ 


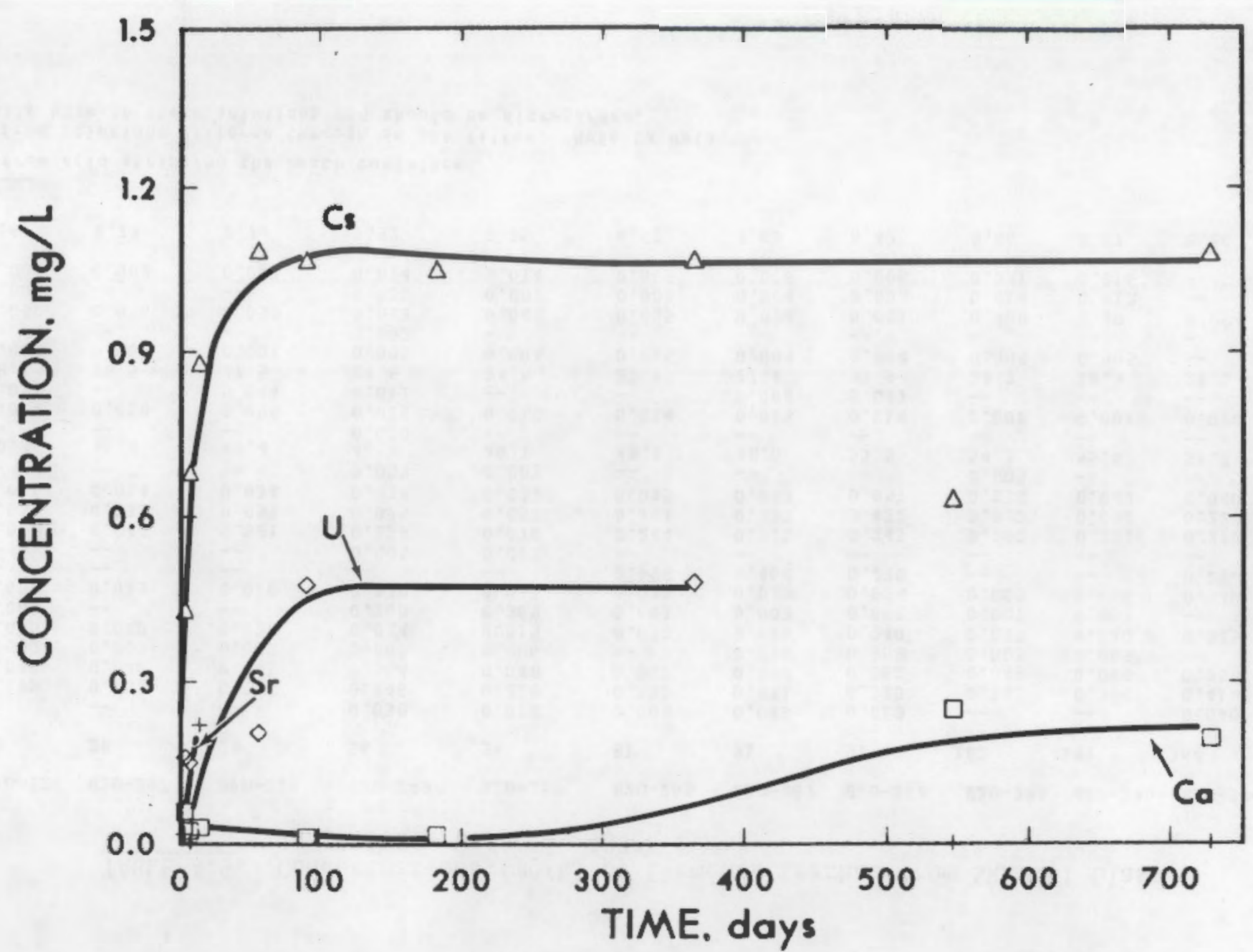

FIGURE A.4. Concentrations $(\mathrm{mg} / \mathrm{L})$ in the Leachates from SRL-131 Glass in Deionized Water at $90^{\circ} \mathrm{C}$ 
TABLE A.5. Concentrations (mg/L) of Elements Leached from SRL-131 Glass in Silicate Water at $40^{\circ} \mathrm{C}$

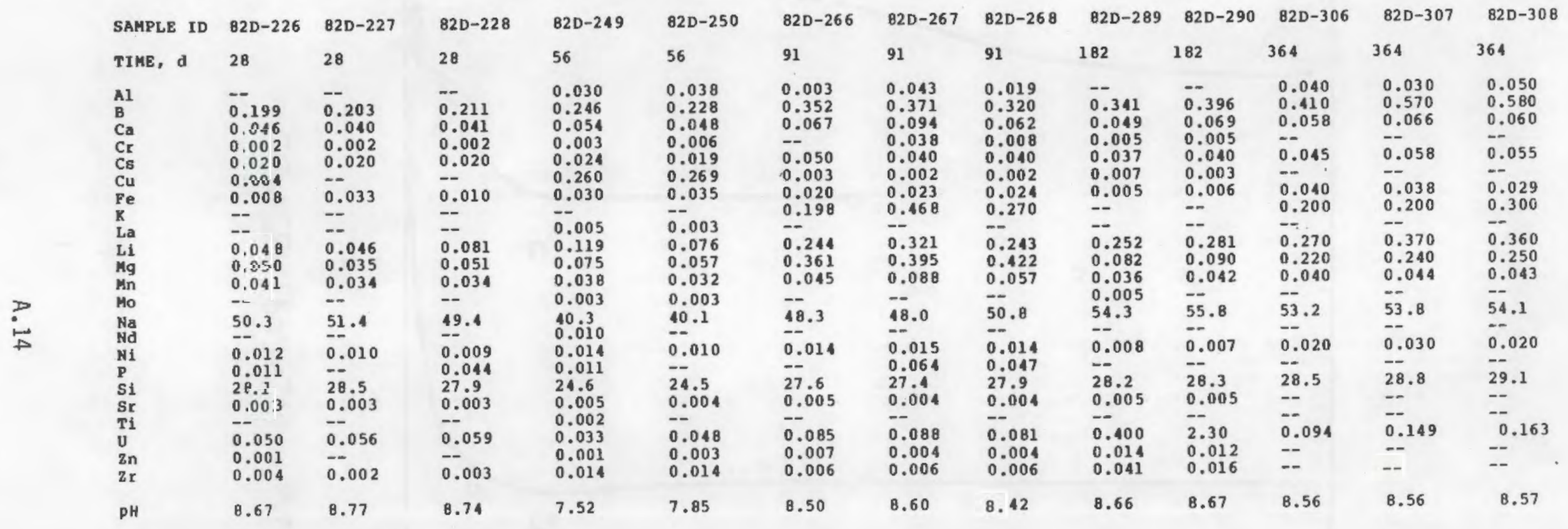

$S$ a results from acid stripping the leach container

$F=$ results from solutions filtered through an $18 \mathrm{~B}^{\circ}$ fllter. Note ca data are usually high in these solutions and should be disregarded. 
TABLE A.7. Concentrations ( $\mathrm{mg} / \mathrm{L}$ ) of Elements Leached from SRL-131 Glass in Silicate water at $90^{\circ} \mathrm{C}$

\begin{tabular}{|c|c|c|c|c|c|c|c|c|c|c|c|c|c|}
\hline SAMPLE IU & $82 D-226$ & a2D-227 & $82 D-228$ & $82 D-249$ & $32 \mathrm{D}-250$ & $82 D-266$ & $82 D-267$ & $82 D-268$ & $82 D-289$ & $82 \mathrm{D}-290$ & $820-306$ & $82 D-307$ & $82 \mathrm{D}-308$ \\
\hline Time, d & 28 & 28 & 28 & 56 & 56 & 91 & 91 & 91 & 182 & 182 & 364 & 364 & 364 \\
\hline Al & -- & -- & -- & 0.19 & 0.24 & 0.019 & 0.27 & 0.12 & -- & -- & -- & -- & -- \\
\hline B & 0.47 & 0.49 & 0.51 & 0.63 & 0.57 & 1.09 & 1.16 & 0.99 & 1.06 & 1.24 & 1.31 & 1.83 & 1.86 \\
\hline $\mathrm{Ca}$ & 0.33 & 0.25 & 0.26 & 0.44 & 0.36 & 0.57 & 0.93 & 0.5 & 0.32 & 0.59 & 0.44 & 0.55 & \\
\hline $\begin{array}{l}\mathrm{Cr} \\
\mathrm{Cs}\end{array}$ & 0.19 & 0.19 & 0.19 & 0.29 & 0.57 & -- & 3.58 & 0.72 & 0.43 & 0.43 & $-x^{-10}$ & $\overline{5}$ & -9 \\
\hline $\begin{array}{l}\text { Cs } \\
\text { Cu }\end{array}$ & 0.71 & 0.71 & 0.71 & 0.85 & 0.67 & 1.77 & 1.41 & 1.41 & 1.31 & 1.41 & 1.59 & 2.05 & 1.54 \\
\hline Fe & 0.004 & 0.029 & 0.006 & $\begin{array}{l}106 \\
0.026\end{array}$ & $\begin{array}{l}110 \\
0.031\end{array}$ & $=$ & -- & - & -- & -- & -- & $\overline{--}$ & - \\
\hline $\mathbf{K}$ & -- & - & -- & $\therefore-$ & -- & 8.68 & 35.8 & 15.9 & -- & -- & -- & -- & 5.02 \\
\hline La & - & $=$ & -- & 0.18 & 0.11 & -- & -- & -- & -- & -- & $=$ & -- & -- \\
\hline $\begin{array}{l}\mathbf{L i} \\
\mathbf{M g}\end{array}$ & $\begin{array}{l}0.26 \\
0.66\end{array}$ & $\begin{array}{l}0.24 \\
0.46\end{array}$ & $\begin{array}{l}0.41 \\
0.68\end{array}$ & 0.65 & 0.41 & 1.35 & 1.78 & 1.35 & 1.4 & 1.56 & 1.5 & $\begin{array}{l}2.05 \\
0.87\end{array}$ & 2 \\
\hline Mn & 0.14 & 0.11 & 0.11 & 0.13 & $0.1^{\circ}$ & $\begin{array}{l}2.9 \\
0.17\end{array}$ & $\begin{array}{l}3.36 \\
0.33\end{array}$ & $\begin{array}{l}3.72 \\
0.22\end{array}$ & $\overline{0.14}$ & $\overline{0.16}$ & 0.15 & 0.17 & $\begin{array}{l}1 \\
0.16\end{array}$ \\
\hline Mo & -- & -- & -- & -- & -- & -- & -1 & - & - & -- & -- & -- & 0.80 \\
\hline Na & -- & 0.27 & -- & -- & -- & 0.82 & 0.55 & 3.1 & 6.3 & 7.67 & 1.92 & 2.46 & 2.74 \\
\hline Nd & -- & -- & -- & 0.26 & -- & -- & -- & -- & - & -- & -- & -- & -- \\
\hline Ni & 0.099 & 0.083 & 0.074 & 0.12 & 0.083 & 0.062 & 0.07 & 0.062 & 0.012 & 0.0041 & -- & 0.083 & -- \\
\hline $\begin{array}{l}P \\
S_{1}\end{array}$ & 0.8 & -- & 8.37 & 0.8 & -- & -- & 2.64 & $-0^{-17}$ & $\overline{0.64}$ & $\overline{0.69}$ & $\overline{0.53}$ & $\overline{0.69}$ & $\overline{0.86}$ \\
\hline $\begin{array}{l}\text { Si } \\
\text { Sr }\end{array}$ & 0.25 & $\begin{array}{l}0.19 \\
0.25\end{array}$ & $\overline{0.25}$ & $\overline{0.42}$ & $\overline{0.34}$ & 0.3 & 0.19 & 0.47 & $\begin{array}{l}0.64 \\
--\end{array}$ & $\begin{array}{l}0.69 \\
--\end{array}$ & 0.53 & 0.69 & 0.86 \\
\hline Ti & $\ldots$ & - & -2 & 0.044 & -.34 & -- & -- & - & - & -- & -- & - & -- \\
\hline $\mathbf{u}$ & 0.35 & 0.39 & 0.42 & 0.23 & 0.33 & 0.6 & 0.61 & 0.57 & 2.8 & 16.1 & 0.66 & 1.04 & 1.14 \\
\hline $\mathrm{zn}_{\mathrm{n}}$ & -- & - & - & -- & -- & -- & -- & -- & -7 & -- & -- & -- & $=$ \\
\hline 25 & -- & -- & -- & -- & -- & -- & -- & -- & 0.78 & -- & -- & -- & -- \\
\hline
\end{tabular}

$S=$ results from acid stripping the leach contalner

$F=$ results from solutions filtered through an $18 \AA^{\circ}$ filter. Note Ca data

are usually high in these solutions and should be disiegarded. 
TABLE A.6. Normalized Elemental Mass Loss $\left(\mathrm{g} / \mathrm{m}^{2}\right)$ for SRL-131 Glass in Silicate Water at $40^{\circ} \mathrm{C}$

\begin{tabular}{|c|c|c|c|c|c|c|c|c|c|c|c|c|c|}
\hline & & $82 D-238$ & $82 D-239$ & $82 D-240$ & $82 D-257$ & $82 D-258$ & $82 D-278$ & $82 D-279$ & $82 D-280$ & $82 D-297$ & $82 \mathrm{D}-297 \mathrm{~F}$ & $82 D-297 S$ & $82 D-298$ \\
\hline & TIME, d & 28 & 28 & 28 & 56 & 56 & 91 & 91 & 91 & 182 & 182 & 182 & 122 \\
\hline & Al & 0.859 & 0.885 & 0.857 & 0.789 & 0.847 & 0.773 & 0.799 & 0.789 & 0.844 & 0.852 & -- & 0.787 \\
\hline & B & 6.19 & 6.17 & 6.43 & 7.66 & 8.07 & 10.5 & 10.3 & 10.6 & 13.9 & 13.3 & 0.099 & 13.7 \\
\hline & Ca & 0.011 & -- & 0.053 & 0.022 & 0.019 & -- & -- & -- & 0.026 & 0.012 & -- & 0.027 \\
\hline & $\mathrm{Cr}$ & $\ldots$ & -- & - & - & -- & -- & -- & -- & 0.025 & 0.022 & -- & 0.023 \\
\hline & Cs & 0.600 & 0.590 & 0.620 & 0.660 & 0.620 & 0.760 & 0.740 & 0.750 & 0.940 & 0.910 & - & 0.940 \\
\hline & $\mathrm{Cu}$ & -- & -- & -- & 0.200 & 0.207 & 0.046 & 0.016 & 0.008 & 0.044 & -- & -- & -- \\
\hline & $\mathrm{Fe}$ & 0.032 & 0.042 & 0.028 & 0.047 & 0.060 & 0.091 & 0.072 & 0.072 & 0.040 & 0.008 & 0.030 & 0.026 \\
\hline & K & -- & -- & $\ldots$ & -- & -- & 0.464 & -- & -- & -- & 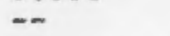 & - & -- \\
\hline & La & -- & -- & - & -- & - & -- & -- & -- & - & - & -- & -- \\
\hline & $\mathbf{L} \dot{i}$ & 4.15 & 4.20 & 4.27 & 4.66 & 4.84 & 7.30 & 7.20 & 7.15 & 8.74 & 9.08 & 0.035 & 8.90 \\
\hline & Mg & -- & - & -- & 0.127 & 0.179 & 0.809 & 0.284 & 0.366 & 0.144 & -- & -- & 0.120 \\
\hline & $\mathrm{Mn}$ & 0.066 & 0.076 & 0.062 & 0.089 & 0.102 & 0.124 & 0.131 & 0.117 & 0.079 & -- & 0.041 & 0.077 \\
\hline & Mo & -- & -- & -- & -- & -- & 0.035 & 0.011 & -- & -- & -- & $\ldots$ & -- \\
\hline & $\mathrm{Na}$ & 78.0 & 79.4 & 78.9 & 64.5 & 65.3 & 79.7 & 79.4 & 77.3 & 91.1 & 99.7 & 0.514 & 94.5 \\
\hline & Nd & $\ldots$ & $\ldots$ & -- & $\ldots$ & -- & -- & - & - & -- & -- & -- & -- \\
\hline & $\mathrm{Ni}$ & -- & 0.029 & -- & 0.032 & 0.042 & 0.090 & 0.073 & 0.072 & 0.020 & -- & -- & 0.025 \\
\hline 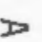 & $\mathbf{P}$ & -- & - & -- & -- & -- & $-\infty$ & -- & -- & - & -- & -- & $\ldots$ \\
\hline 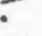 & Si & 51.3 & 51.4 & 51.9 & 48.2 & 49.9 & 57.8 & 57.5 & 57.8 & 68.3 & 68.5 & 0.474 & 67.4 \\
\hline • & $\mathrm{Sr}$ & -- & -- & -- & 0.002 & 0.004 & 0.033 & 0.010 & 0.003 & -- & - & -- & -- \\
\hline & $\mathbf{T i}$ & -- & -- & -- & -- & - & 0.028 & 0.003 & - & -- & -- & -- & -- \\
\hline & U & 0.708 & 0.763 & 0.596 & 0.997 & 0.900 & 0.735 & 0.818 & 0.490 & 1.30 & -- & -- & 3.20 \\
\hline & $\mathrm{zn}$ & $\ldots$ & - & -- & $=$ & - & 0.042 & $-\infty$ & - & -- & 0.529 & -- & $\ldots$ \\
\hline & $\mathrm{Z \tau}$ & -- & -- & -- & -- & -- & 0.040 & 0.011 & -- & 0.009 & -- & -- & -- \\
\hline & pit & 9.70 & 9.70 & 9.72 & 9.71 & 9.83 & 9.76 & 9.73 & 9.70 & 9.77 & 9.77 & 9.77 & 9.873 \\
\hline
\end{tabular}

$S=$ results from acid stripping the leach container

$F=$ results from solutions filtered through an $18 \AA$ filter: No:e Ca data are usually high in these solutions and should be disregarded. 
TABLE A.6. (contd)

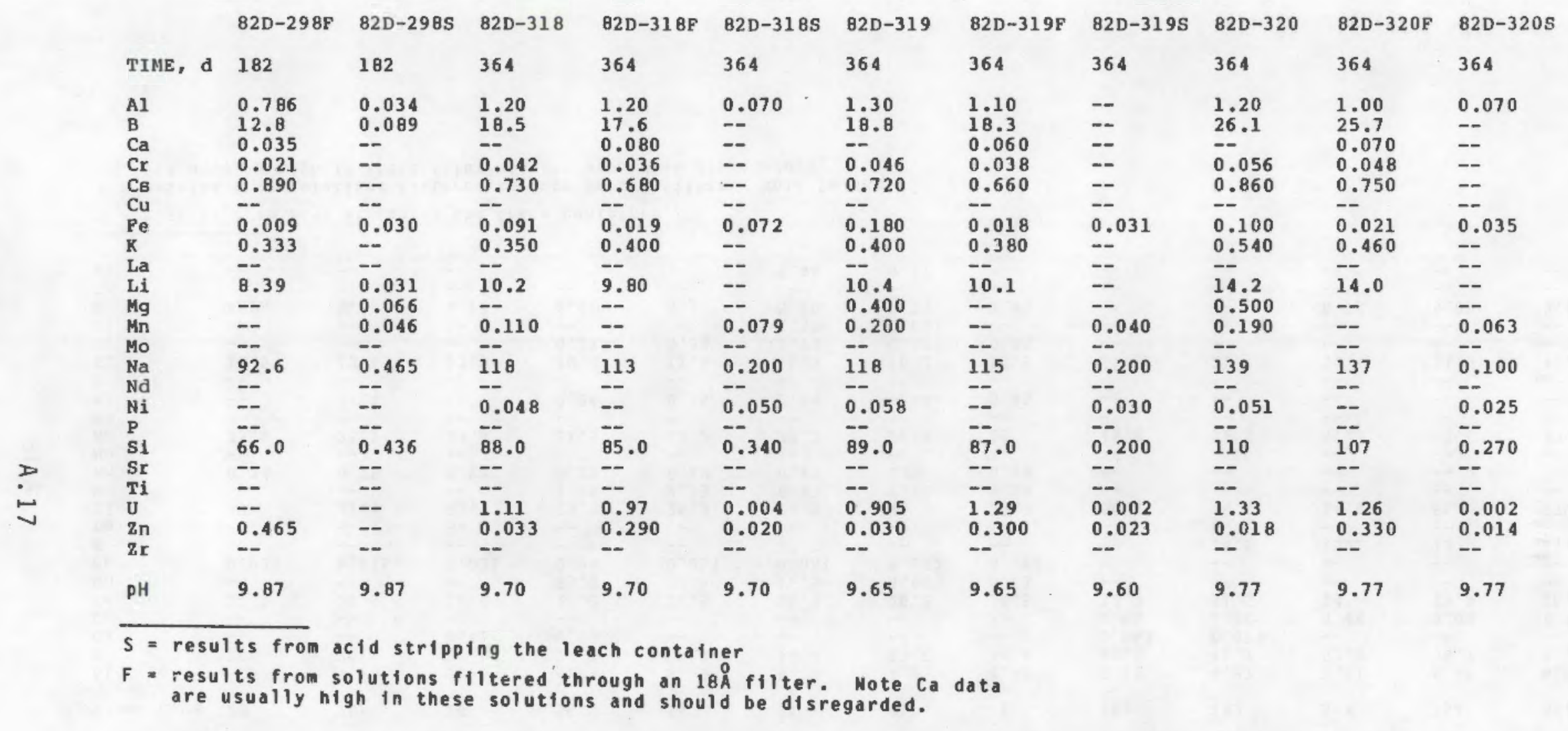


TABLE A.8. Normalized Elemental Mass Loss $\left(\mathrm{g} / \mathrm{m}^{2}\right)$ for SRL-131 Glass in Silicate Water at $90^{\circ} \mathrm{C}$

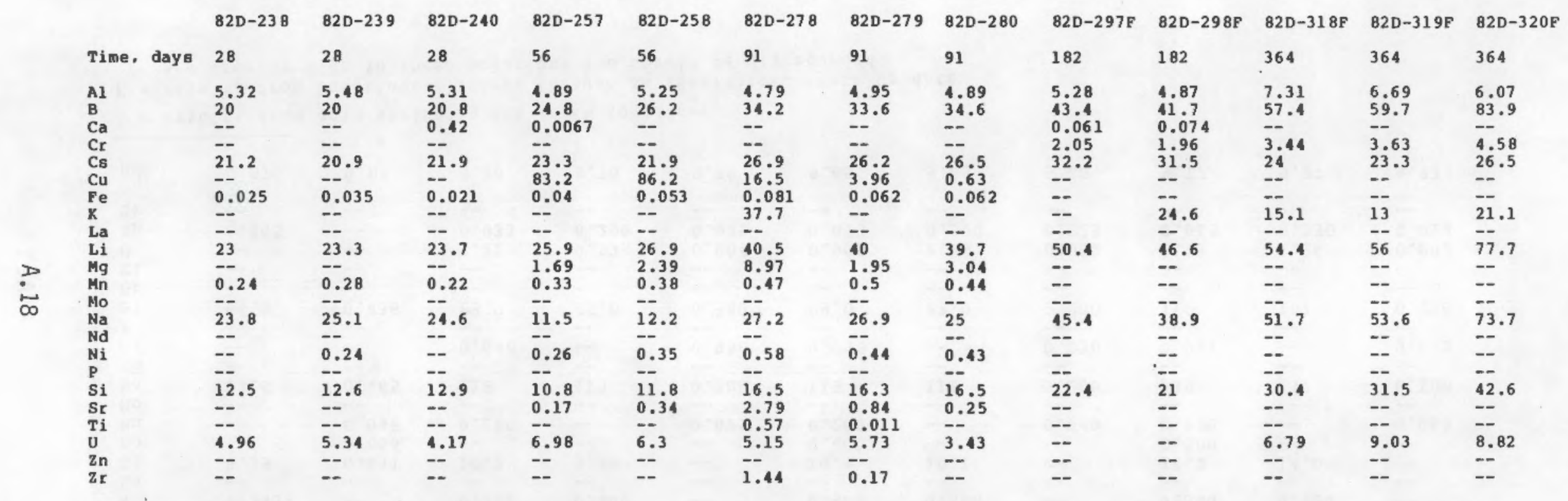

$S=$ results from acid stripping the leach contalner

$F=$ results from solutions filtered through an $18 \AA^{\circ}$ fliter. Note ca data are usually high in these solutions and should be disregarded. 


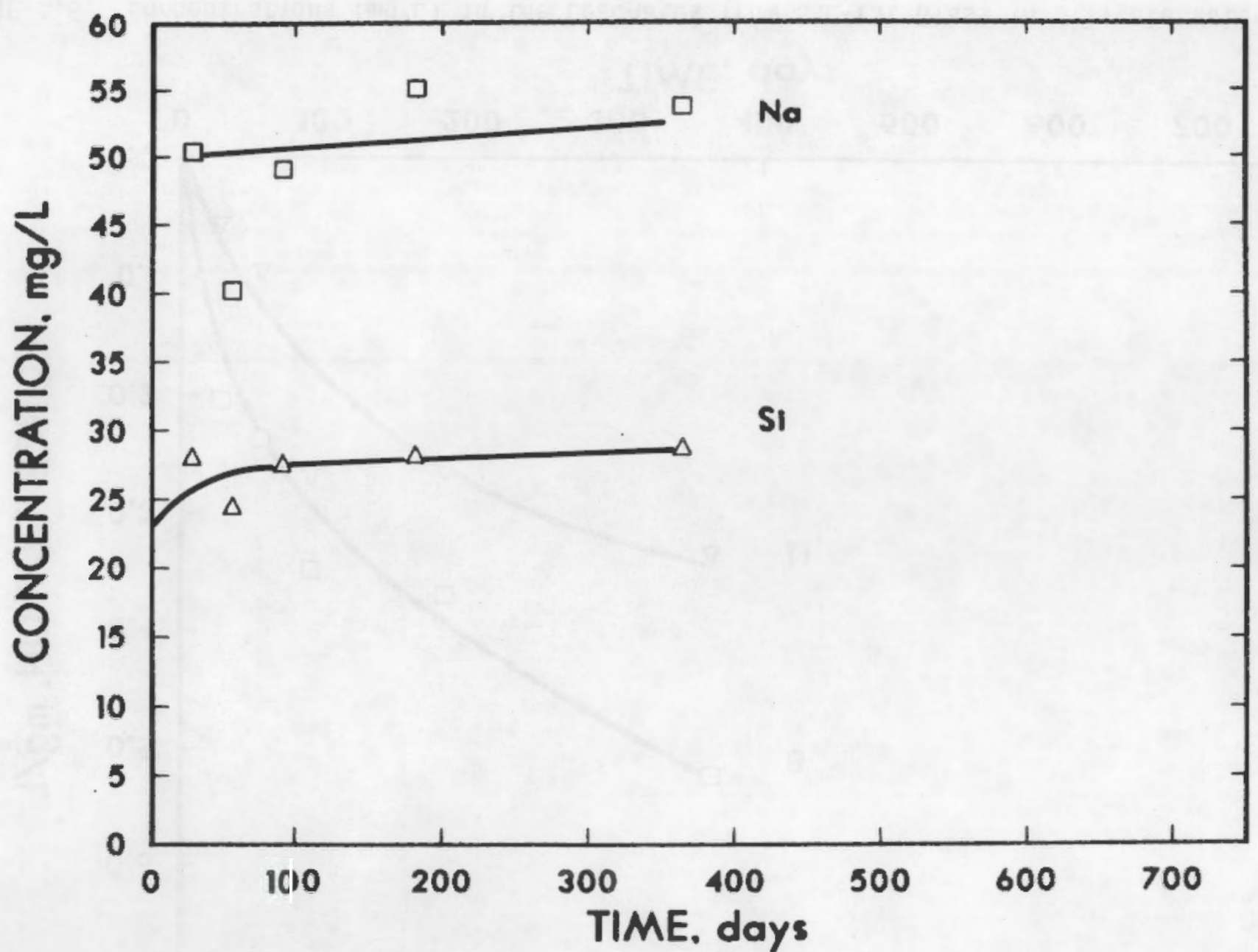

FIGURE A.5. Concentrations $(\mathrm{mg} / \mathrm{L})$ in the Leachates from SRL-131. Glass in Silicate Water at $40^{\circ} \mathrm{C}$ 


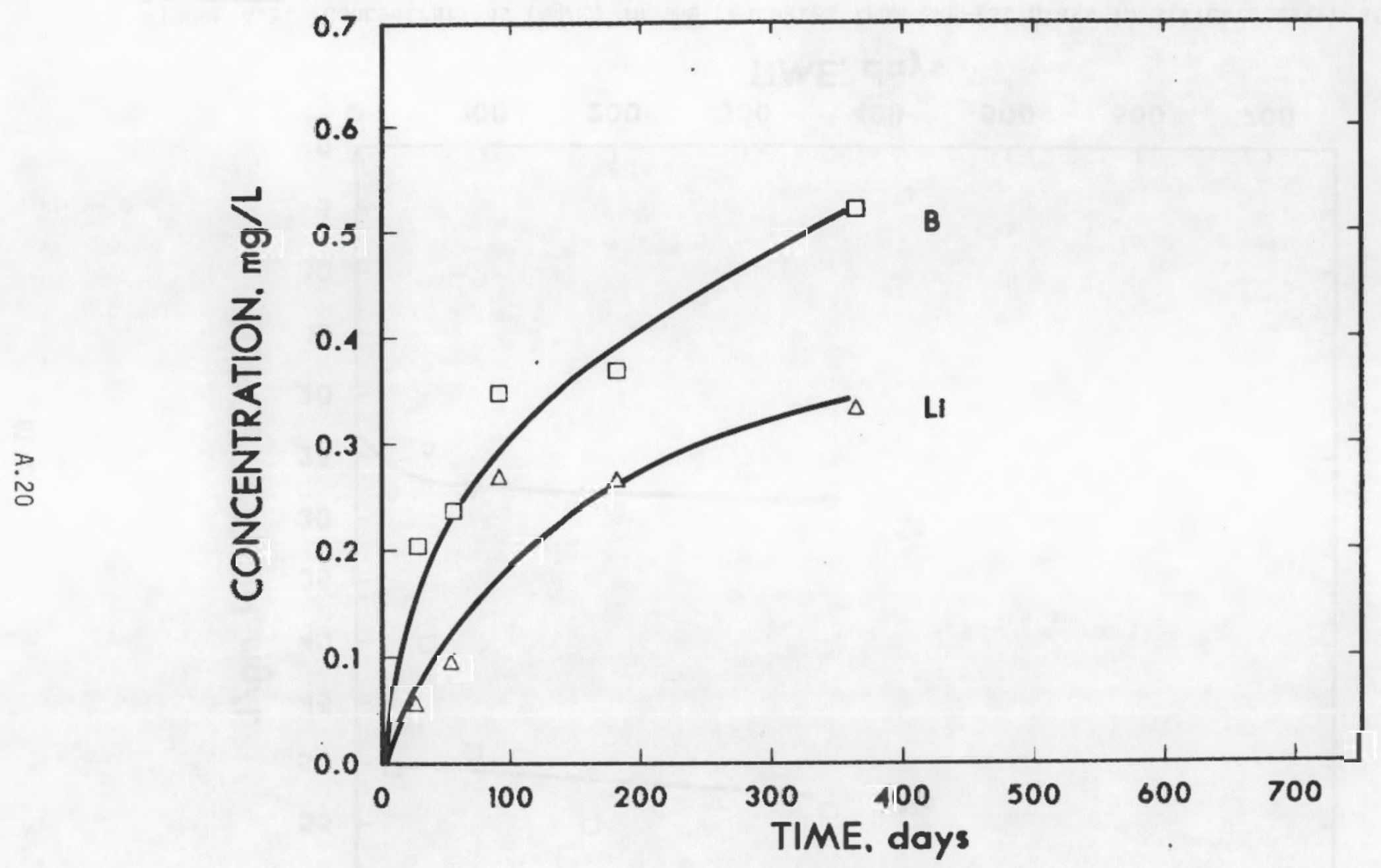

FIGURE A.6. Concentrations (mg/L) in the Leachates from SRL-131 Glass in Silicate water at $40^{\circ} \mathrm{C}$ 


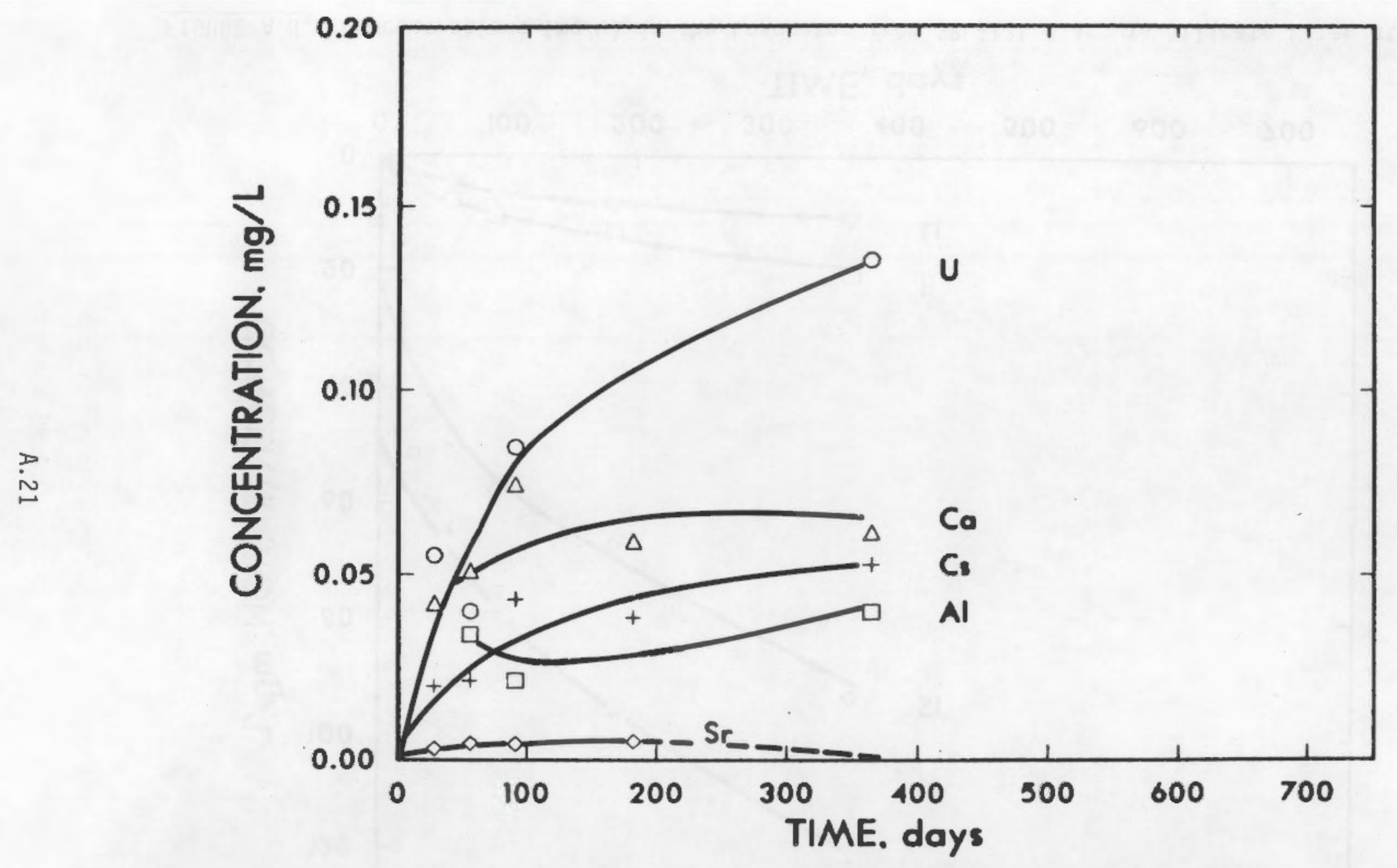

FIGURE A.7. Concentrations $(\mathrm{mg} / \mathrm{L})$ in the Leachates from SRL-131 Glass in Silicate water at $40^{\circ} \mathrm{C}$ 


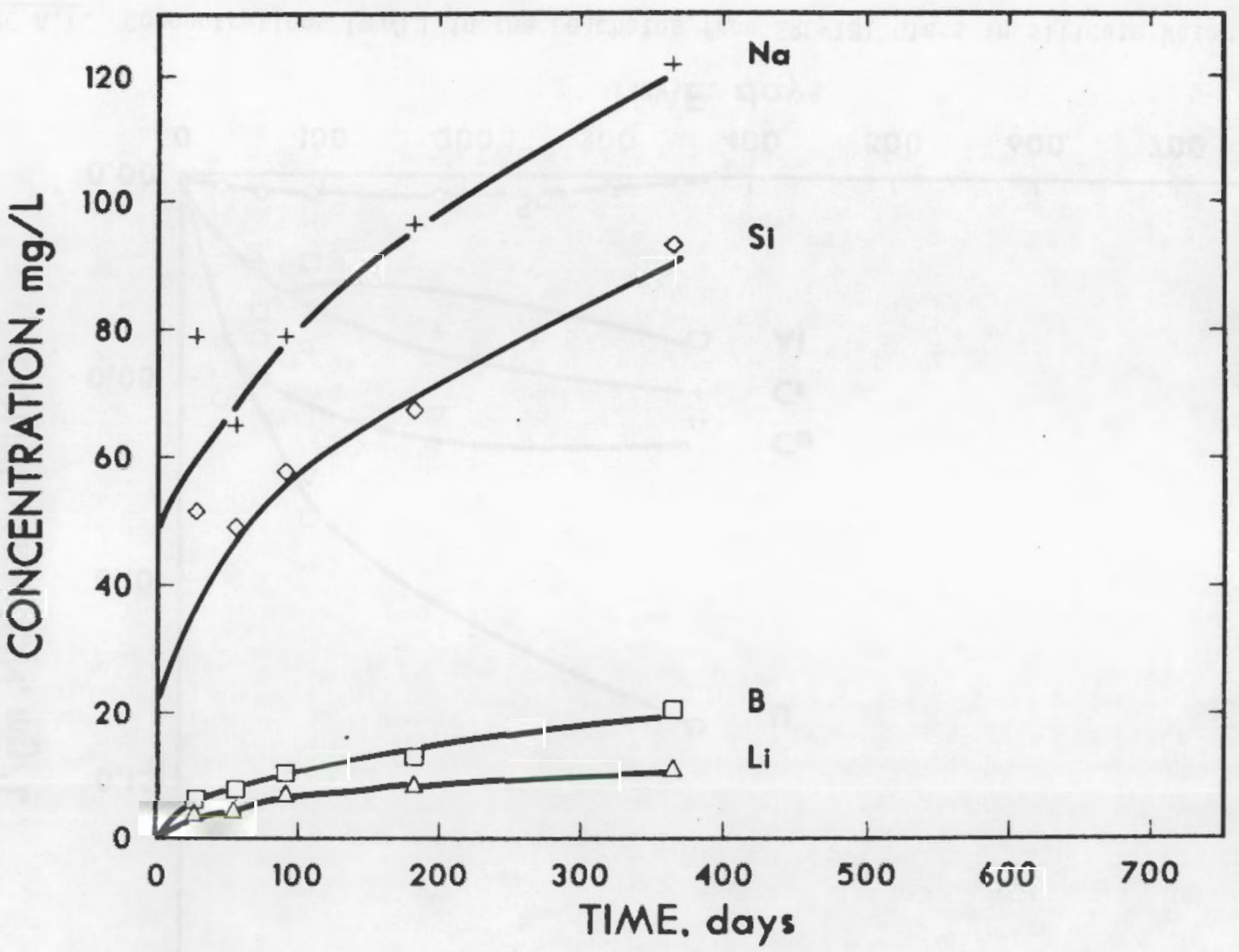

FIGURE A.8. Concentrations $(\mathrm{mg} / \mathrm{L})$ in the Leachates from SRL-131 Glass in Silicate Water at $90^{\circ} \mathrm{C}$ 


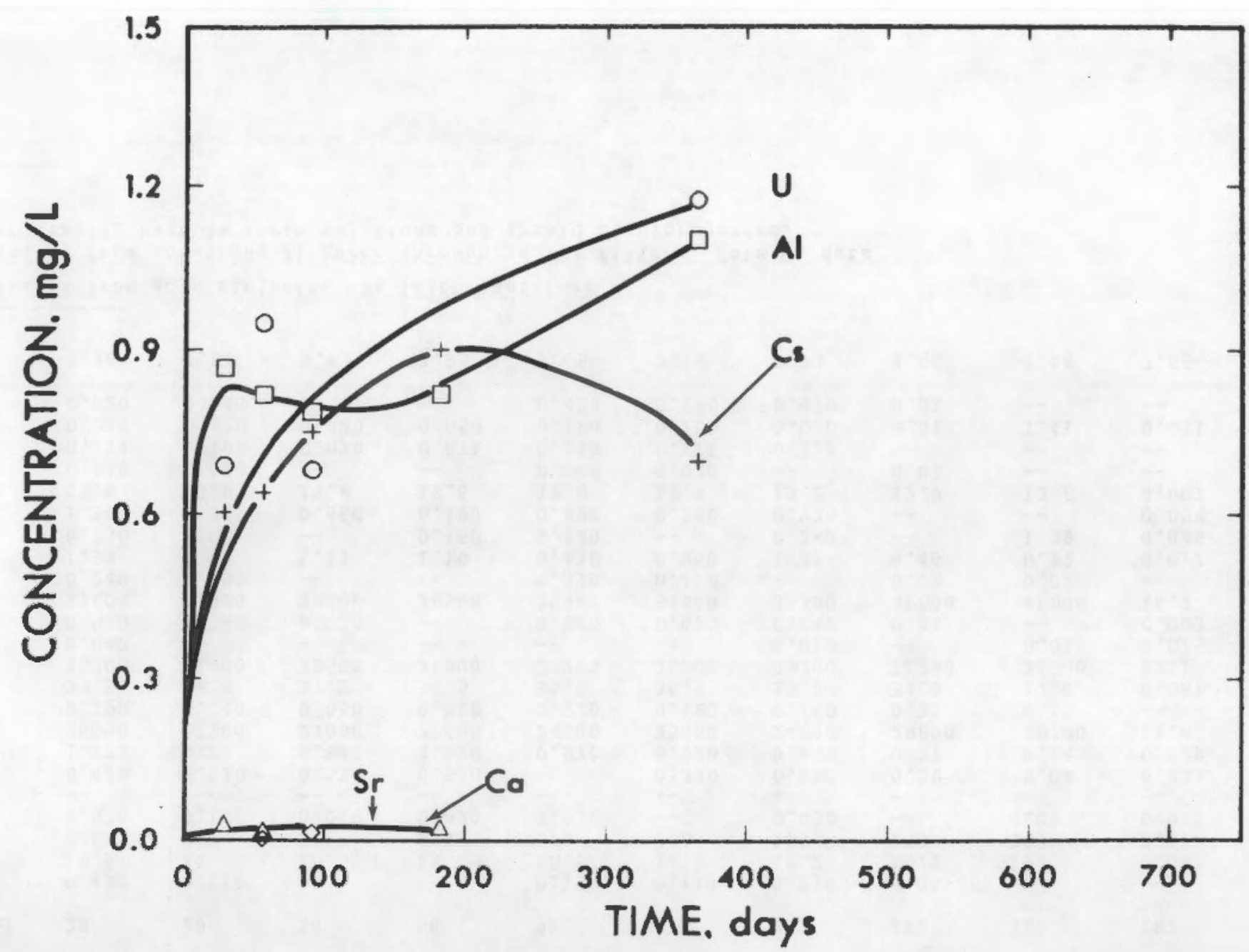

FIGURE A.9. Concentrations $(\mathrm{mg} / \mathrm{L})$ in the Leachates from SRL-131 Glass in Silicate Water at $90^{\circ} \mathrm{C}$ 
TABLE A.9. Concentrations ( $\mathrm{mg} / \mathrm{L}$ ) of Elements from SRL-131 Glass in Salt Brine at $40^{\circ} \mathrm{C}$

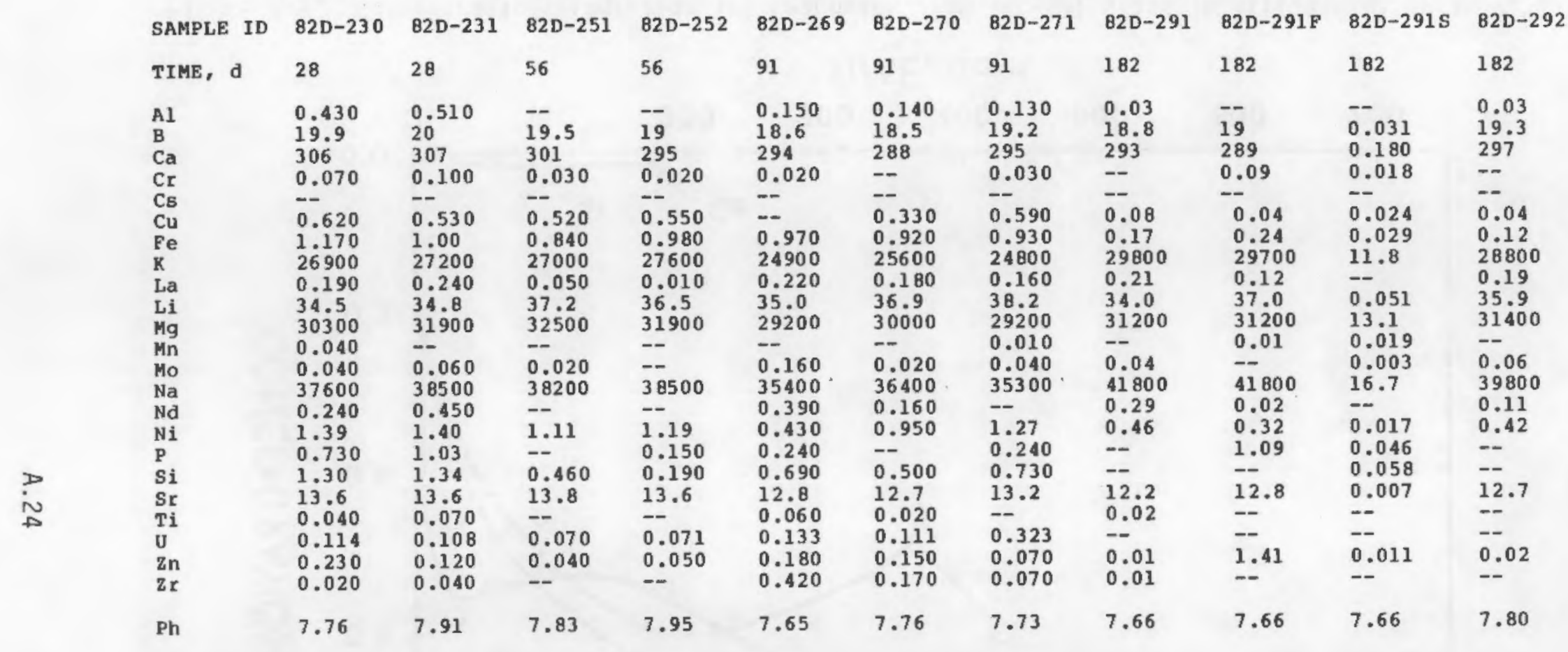

$S$ * results from acid stripping the leach container

$F=$ results from solutions flltered through an $18 \AA$ filter. Note Ca data are usually high in these solutions and should be disregarded. 
TABLE A.9. (contd)

\begin{tabular}{|c|c|c|c|c|c|c|c|c|c|c|c|}
\hline SAMPLE ID & $82 D-292 F$ & $82 D-292 S$ & $82 D-309$ & $82 D-310$ & $82 \mathrm{D}-311$ & $82 \mathrm{D}-330$ & $82 D-331$ & $82 \mathrm{D}-332$ & $82 \mathrm{D}-342$ & $82 D-343$ & $82 \mathrm{D}-344$ \\
\hline TIME, $d$ & 182 & 132 & 364 & 364 & 364 & 546 & 546 & 546 & 728 & 728 & 728 \\
\hline Al & -- & -- & -- & -- & -- & 2.43 & 2.61 & 2.43 & 1.10 & 0.838 & 0.045 \\
\hline B & 19.3 & 0.050 & 19.3 & 19.4 & 19.3 & 20.6 & 20.9 & 20.6 & 20.0 & 20.0 & 2.00 \\
\hline $\mathrm{Ca}$ & 290 & 0.815 & 313 & 314 & 313 & $240^{\circ}$ & 236 & $244^{\circ}$ & 307 & 303 & 300 \\
\hline $\mathrm{Cr}$ & -- & 0.006 & 0.043 & 0.029 & 0.157 & 1.44 & 1.44 & 1.34 & 0.210 & 0.160 & 0.009 \\
\hline $\begin{array}{l}\text { Cs } \\
\text { Cu }\end{array}$ & -- & $\overline{0.028}$ & $=-$ & $=$ & $=$ & $=$ & $=$ & $=-$ & $=$ & $=$ & $=$ \\
\hline $\mathbf{F e}$ & $=$ & 0.038 & 1.19 & 1.13 & 1.21 & 0.683 & 0.864 & $\overline{0.576}$ & 1.35 & 0.102 & 0.092 \\
\hline K & 28000 & 64.8 & 27000 & 26857 & $\begin{array}{l}1.21 \\
26514\end{array}$ & $\begin{array}{l}0.683 \\
24816\end{array}$ & $\begin{array}{l}0.864 \\
24759\end{array}$ & 24759 & $\begin{array}{l}1.35 \\
25294\end{array}$ & $\begin{array}{l}0.102 \\
25013\end{array}$ & $\begin{array}{l}0.092 \\
25080\end{array}$ \\
\hline $\mathrm{La}$ & 0.04 & -- & 0.052 & - & -- & -- & & & 0.096 & $\begin{array}{l}25013 \\
0.077\end{array}$ & 0.034 \\
\hline $\mathrm{Li}$ & 40.4 & 0.108 & 34.0 & 34.1 & 34.0 & 27.6 & 27.9 & 27.8 & 35.7 & 35.7 & 36.0 \\
\hline $\mathrm{Mg}$ & 31400 & 74.3 & 32678 & 32452 & 31967 & 30265 & 30102 & 30157 & 30814 & 30305 & 30458 \\
\hline Mn & -- & 0.007 & 0.244 & 0.220 & 0.205 & 0.225 & 0.225 & 0.271 & 1.01 & 0.013 & 0.784 \\
\hline Mo & -- & -- & -- & 0.018 & --200 & 0.174 & 0.124 & 0.199 & 0.052 & 0.052 & 0.029 \\
\hline $\mathrm{Na}$ & 39800 & 85.7 & 38803 & 38757 & 38261 & 36157 & 36062 & 35827 & 36546 & 35840 & 36299 \\
\hline Nd & -- & -- & 0.042 & 0.095 & 0.095 & -2 & -- & -- & 0.514 & 0.422 & 0.020 \\
\hline $\mathbf{N i}$ & 0.31 & 0.020 & 1.52 & 1.45 & 1.45 & 1.03 & 1.03 & 0.989 & 2.12 & 1.64 & 1.55 \\
\hline P & 0.11 & 0.124 & 0.515 & 0.811 & 0.516 & 11.4 & 10.9 & 11.7 & 0.788 & 0.481 & 0.350 \\
\hline Si & $\cdots$ & -- & 2.44 & 2.31 & 1.95 & 3.07 & 2.94 & 2.54 & 6.67 & 5.15 & 4.71 \\
\hline Sr & 13.1 & 0.033 & 13.9 & 13.9 & 13.9 & -- & & & 13.1 & 13.0 & 13.1 \\
\hline $\mathbf{T i}$ & -- & -- & 0.013 & -- & -- & 0.055 & 0.041 & 0.028 & 0.053 & 0.039 & 0.007 \\
\hline $\mathrm{U}$ & -- & -- & & -- & -- & -- & & & & & \\
\hline $\mathrm{zn}$ & 1.55 & 0.020 & 0.100 & 0.148 & 0.132 & -- & -- & -- & 0.162 & 0.156 & 0.148 \\
\hline $\mathrm{zr}$ & -- & -- & & & & 0.087 & 0.058 & 0.044 & 0.043 & 0.027 & -- \\
\hline pH & 7.80 & 7.80 & 7.75 & 7.85 & 7.90 & 7.20 & 7.16 & 7.24 & 7.14 & 7.14 & 7.14 \\
\hline
\end{tabular}

$S=$ results from acid stripping the leach container

$F=$ results from solutions filtered through an $18 \AA$ filter. Wote Ca data

are usualiy high in these solutions and should be disregarded. 
TABLE A.10. Normalized Elemental Mass Loss $\left(\mathrm{g} / \mathrm{m}^{2}\right)$ for SRL-131 Glass in Salt Brine at $40^{\circ} \mathrm{C}$

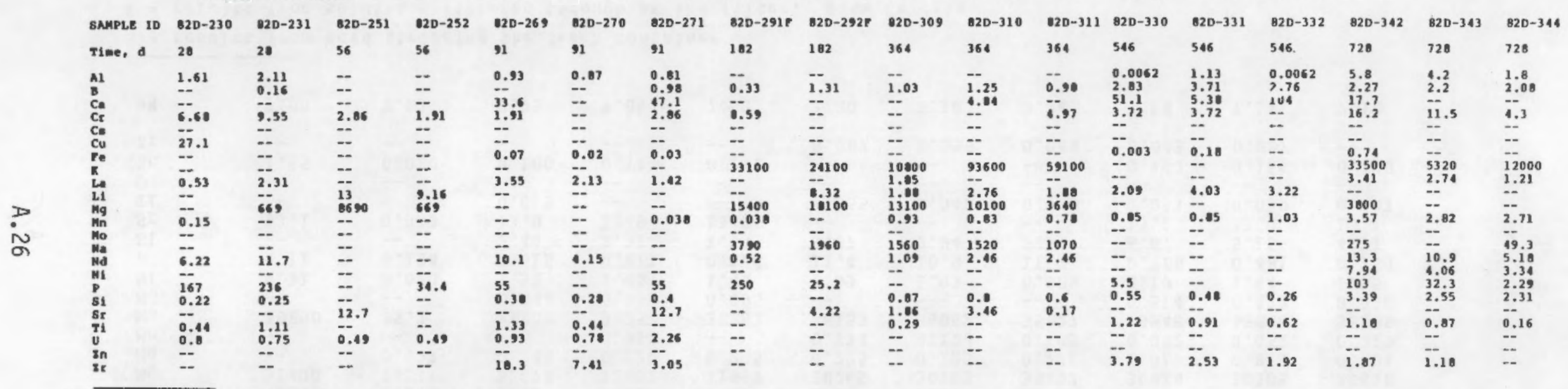

5- results from acte stripping the leach contalngr

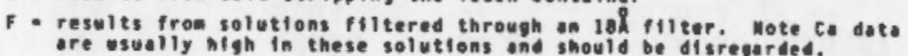


TABLE A.11. Concentrations (mg/L) of Elements Leached from SRL-131 Glass in Salt Brine at $90^{\circ} \mathrm{C}$

\begin{tabular}{|c|c|c|c|c|c|c|c|c|c|c|c|c|}
\hline & $82 D-241$ & $32 \mathrm{D}-242$ & $82 \mathrm{D}-243$ & คาD-259 & $82 \mathrm{D}-260$ & $82 \mathrm{D}-281$ & $82 \mathrm{D}-282$ & $82 D-283$ & $82 \mathrm{D}-299$ & $82 \mathrm{D}-299 \mathrm{~F}$ & $82 D-299 S$ & $82 D-300$ \\
\hline TIME, $d$ & 28 & 28 & 28 & 56 & 56 & 91 & 91 & 91 & 182 & 182 & 182 & 182 \\
\hline A & 0.42 & 0.96 & 0.39 & $\bar{m}$ & $\bar{m}$ & 0.39 & 0.35 & $\bar{m}$ & 0.12 & $\bar{m}$ & -- & 0.16 \\
\hline B & 20.5 & 20.3 & 20.5 & 20.8 & 20.9 & 21.2 & 21.8 & 21.1 & 23.8 & 23.4 & 0.06 & 24.0 \\
\hline $\mathrm{Ca}$ & 304 & 303 & 304 & 307 & 305 & 302 & 309 & 300 & 312 & 303 & 0.59 & 317 \\
\hline $\mathrm{Cr}$ & -- & -- & -- & -- & -- & -- & -- & -- & -- & 0.03 & -- & -- \\
\hline $\begin{array}{l}\text { Cs } \\
\text { C }\end{array}$ & $\overline{0.56}$ & $\overline{0.64}$ & $\overline{0.55}$ & 0.17 & 0.27 & $\overline{0.52}$ & $\overline{0.60}$ & $\overline{0.55}$ & $\overline{0.12}$ & $\overline{0.14}$ & & $\overline{0.19}$ \\
\hline $\mathrm{Fe}$ & 1.35 & 1.31 & 1.34 & 0.93 & 0.91 & 1.03 & 1.11 & 1.24 & 0.08 & --14 & 0.04 & 0.10 \\
\hline $\mathrm{K}$ & 27900 & 28500 & 29400 & 26900 & 27500 & 27100 & 25900 & 25000 & 32100 & 32100 & 55.9 & 29800 \\
\hline L. & 0.24 & 0.35 & 0.25 & & & 0.20 & 0.19 & 0.17 & 0.18 & 0.12 & -- & 0.21 \\
\hline $\mathbf{L i}$ & 34.3 & 33.9 & 34.2 & 39.4 & 39.1 & 38.6 & 40.6 & 39.3 & 39.9 & 41.7 & 0.09 & 39.5 \\
\hline Mg & 31900 & 32400 & 32000 & 31600 & 32000 & 30300 & 30100 & 29700 & 33300 & 33300 & 59.4 & 33200 \\
\hline Mn & 0.30 & 0.33 & 0.31 & 0.13 & 0.21 & 0.58 & 0.50 & 0.46 & & 0.10 & 0.07 & -- \\
\hline Mo & -- & - & 0.24 & 0.15 & -- & -- & 0.10 & -- & 0.09 & -- & -- & 0.12 \\
\hline $\mathrm{Na}$ & 39300 & 40300 & 40500 & 37100 & 37900 & 38600 & 36800 & 35700 & 44000 & 44000 & 73.9 & 41200 \\
\hline Na & 0.30 & 0.84 & 0.39 & - & -- & -- & -- & $-\infty$ & 0.11 & -- & -- & 0.13 \\
\hline Ni & 1.41 & 1.44 & 1.42 & 1.02 & 0.98 & 1.29 & 1.27 & 1.19 & 0.07 & 0.09 & 0.04 & 0.10 \\
\hline $\mathbf{P}$ & - & -- & $\cdots$ & - & -- & -- & - & - & -- & 0.46 & 0.01 & 0.00 \\
\hline si & 3.79 & 4.15 & 3.78 & 4.36 & 4.57 & 6.94 & 7.09 & 6.31 & 1.89 & 1.27 & -- & 2.05 \\
\hline sr & 13.5 & 13.4 & 13.5 & 14.4 & 14.4 & 13.5 & 13.9 & 13.5 & 13.5 & 13.6 & 0.03 & 13.7 \\
\hline $\mathbf{T i}$ & 0.06 & 0.09 & 0.08 & -- & -- & -- & -- & 0.01 & -- & -- & 0.01 & - \\
\hline v & 0.01 & 0.01 & 0.01 & 0.02 & 0.02 & 0.03 & 0.03 & 0.03 & -- & -- & 0.00 & -- \\
\hline $\mathrm{zn}$ & -- & -- & -- & -- & -- & -- & - & - & 0.06 & 1.74 & 0.01 & 0.08 \\
\hline $\mathrm{zr}$ & -- & 0.09 & 0.73 & 0.29 & -- & -- & -- & -- & -- & - & -- & -- \\
\hline Ph & 8.20 & 8.32 & 8.14 & 8.12 & 7.90 & 7.53 & 7.76 & 7.67 & 6.61 & 6.61 & 6.61 & 67.0 \\
\hline
\end{tabular}

$S=$ results from acid stripping the leach contalner

$F=$ results from solutions flltered through an $18 \AA$ filter. Note Ca data are usually high in these solutions and should be disregarded. 
TABLE A.11. (contd)

\begin{tabular}{|c|c|c|c|c|c|c|c|c|c|c|c|}
\hline & $82 \mathrm{D}-300 \mathrm{~F}$ & $82 \mathrm{D}-300 \mathrm{~S}$ & $82 D-321$ & $82 \mathrm{D}-321 \mathrm{~F}$ & $82 \mathrm{D}-321 \mathrm{~S}$ & $82 D-322$ & $82 \mathrm{D}-322 \mathrm{~F}$ & $82 \mathrm{D}-322 \mathrm{~S}$ & $82 D-323$ & $82 \mathrm{D}-323 \mathrm{~F}$ & $82 D-323 s$ \\
\hline TIME, $d$ & 182 & 182 & 364 & 364 & 364 & 364 & 364 & 364 & 364 & 364 & 364 \\
\hline Al & 0.02 & -- & -- & -- & 0.05 & -- & -- & 0.03 & -- & -- & 0.04 \\
\hline B & 23.2 & 0.04 & 24.6 & 23.5 & 0.07 & 24.5 & 23.6 & 0.05 & 27.4 & 26.6 & 0.09 \\
\hline $\mathrm{Ca}$ & 305 & 0.32 & 335 & 330 & 0.13 & 337 & 329 & 0.09 & 333 & 331 & 0.11 \\
\hline $\mathrm{Cr}$ & 0.02 & -- & -- & -- & -- & - & -- & -- & -- & -- & -- \\
\hline $\mathrm{Cs}$ & -- & -- & -- & -- & -- & -- & -- & -- & -- & -- & -. \\
\hline $\mathrm{Cu}$ & 0.18 & 0.01 & -- & -- & -- & -- & -- & -- & -- & -- & -- \\
\hline $\mathbf{F e}$ & 0.02 & 0.03 & 1.10 & 0.16 & 0.18 & 1.10 & 0.19 & 0.16 & 1.00 & -- & 0.22 \\
\hline K & 29800 & 27.9 & 29400 & 29000 & 12.4 & 29000 & 28600 & 8.9 & 29000 & 28600 & 11.5 \\
\hline $\mathbf{L a}$ & 0.15 & - & $\overline{-}$ & $-\bar{x}$ & -- & & & $=-$ & & & \\
\hline Li & 40.6 & 0.04 & 39.9 & 39.5 & 0.02 & 40.0 & 40.2 & 0.01 & 41.4 & 41.2 & 0.02 \\
\hline Mg & 33200 & 31.5 & 35500 & 35100 & 17.4 & 35200 & 34700 & 12.4 & 35000 & 34600 & 18.8 \\
\hline Mn & 0.13 & 0.05 & -- & -- & -- & -- & -- & -- & -- & -- & $\cdots$ \\
\hline Mo & -- & -- & -- & -- & -- & -- & -- & -- & -- & -- & -- \\
\hline $\mathrm{Na}$ & 41200 & 37.9 & 42800 & 42100 & 18.0 & 42400 & 42100 & 13.0 & 42400 & 41700 & 17.0 \\
\hline $\begin{array}{l}\mathrm{Nd} \\
\mathrm{N} \mathrm{i}\end{array}$ & $\begin{array}{l}0.04 \\
0.12\end{array}$ & 0.04 & $\overline{1.10}$ & $\overline{0.20}$ & $\overline{0.11}$ & $\overline{1.30}$ & $\overline{0.10}$ & $\overline{0.08}$ & $\overline{1.50}$ & $\overline{0.20}$ & $\overline{0.19}$ \\
\hline P & 1.77 & 0.05 & $=$ & -- & -- & - & -- & - & -- & -- & -- \\
\hline Si & 1.33 & -- & 11.5 & 0.70 & 1.30 & 12.7 & 0.80 & 1.00 & 21.2 & 5.00 & 3.00 \\
\hline $\mathbf{S} \mathbf{r}$ & 13.6 & 0.01 & 15.0 & 14.8 & -- & 15.0 & 15.0 & -- & 15.0 & 15.0 & \\
\hline $\mathrm{Ti}$ & & -- & & - & -- & -- & -- & -- & -- & - & -- \\
\hline U & -- & -- & -- & $\because$ & -- & -- & -- & - & -- & & -- \\
\hline $2 n$ & 1.72 & 0.01 & 0.14 & 1.60 & - & 0.14 & 1.40 & -- & 0.14 & 1.60 & -- \\
\hline $\mathrm{zr}$ & -- & & -- & -- & - & -- & -- & - & -- & -- & -- \\
\hline PH & 67.0 & 6.70 & 7.61 & 7.61 & 7.61 & 7.42 & 7.42 & 7.42 & 6.50 & 6.50 & 6.50 \\
\hline
\end{tabular}

$S=$ results from acid stripping the leach container

$F=$ results from solutions flltered through an $18 \AA$ fflter. Wote ca data

are usually high in these solutions and should be disregarded. 
TABLE A.12. Normalized Elemental Mass Loss $\left(\mathrm{g} / \mathrm{m}^{2}\right)$ for SRL-131 Glass in Salt Brine at $90^{\circ} \mathrm{C}$

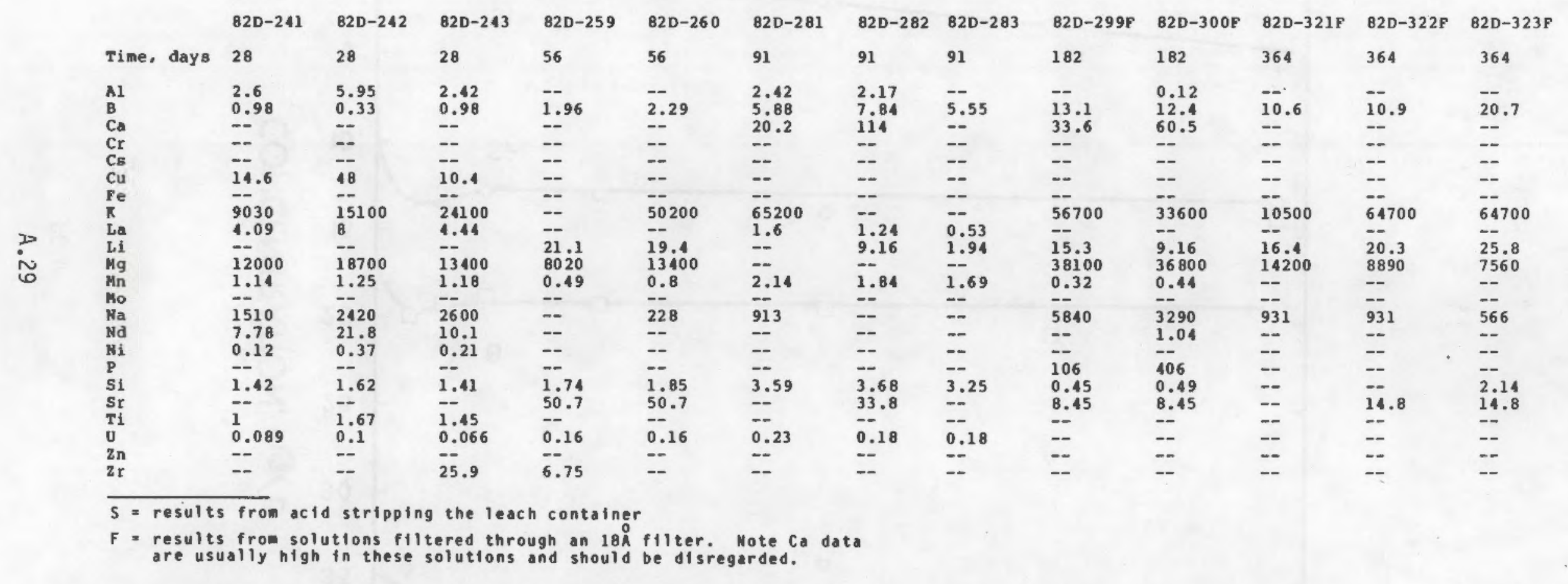




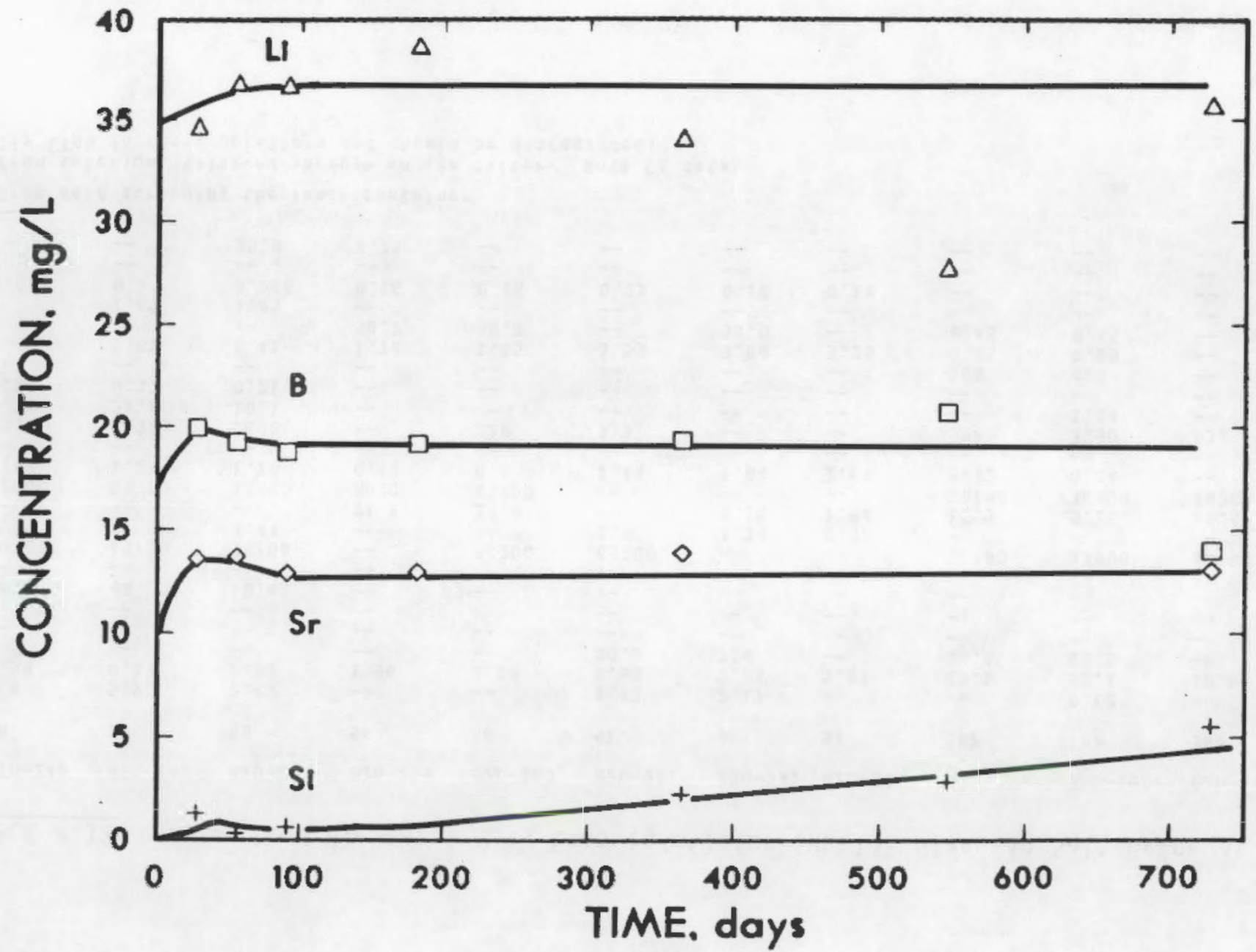

FIGURE A.10. Concentrations (mg/L) in the Leachates from SRL-131 Glass in Salt Brine at $40^{\circ} \mathrm{C}$ 


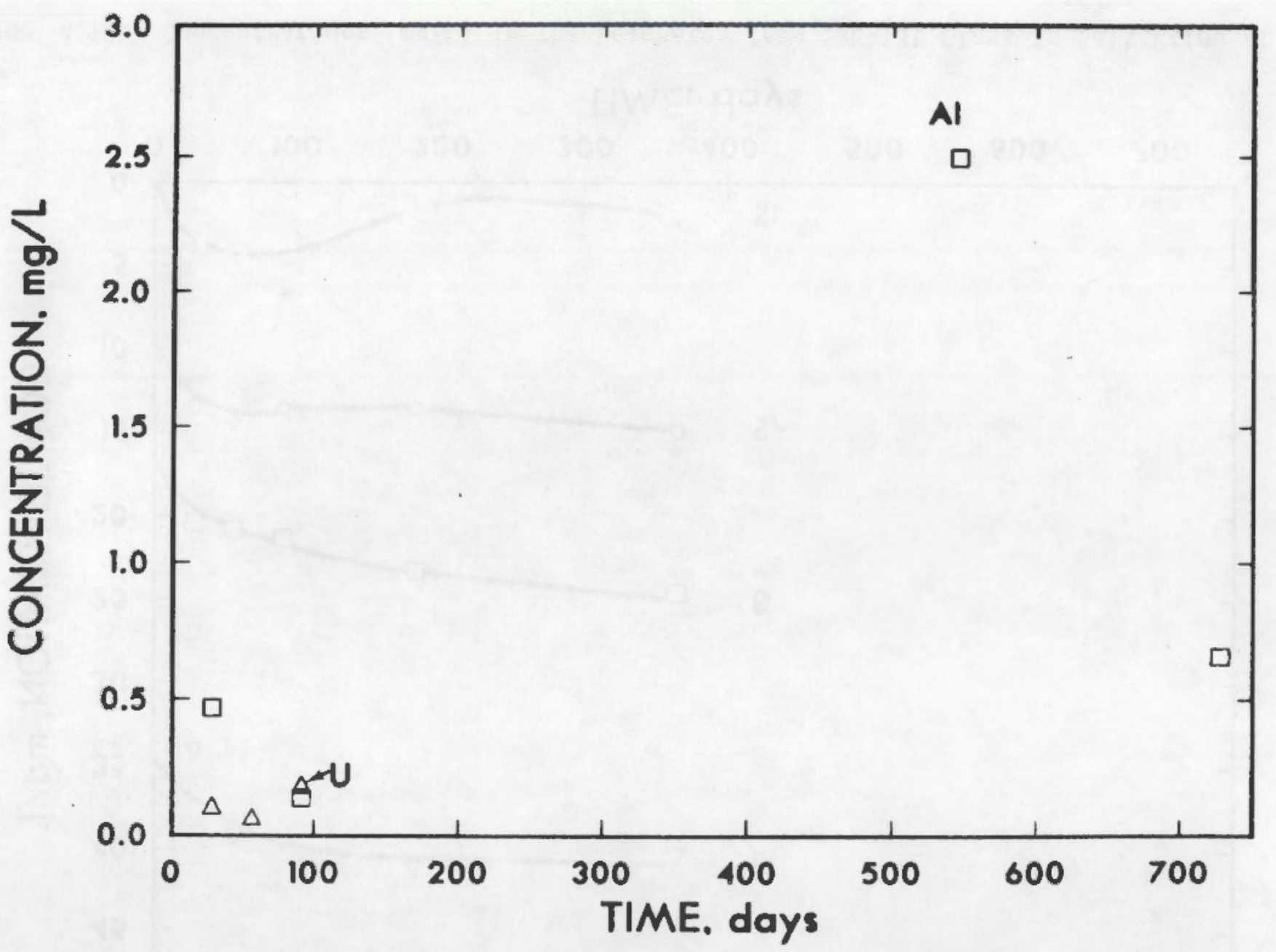

FIGURE A.11. Concentrations $(\mathrm{mg} / \mathrm{L})$ in the Leachates from SRL-131 Glass in Salt Brine at $40^{\circ} \mathrm{C}$ 


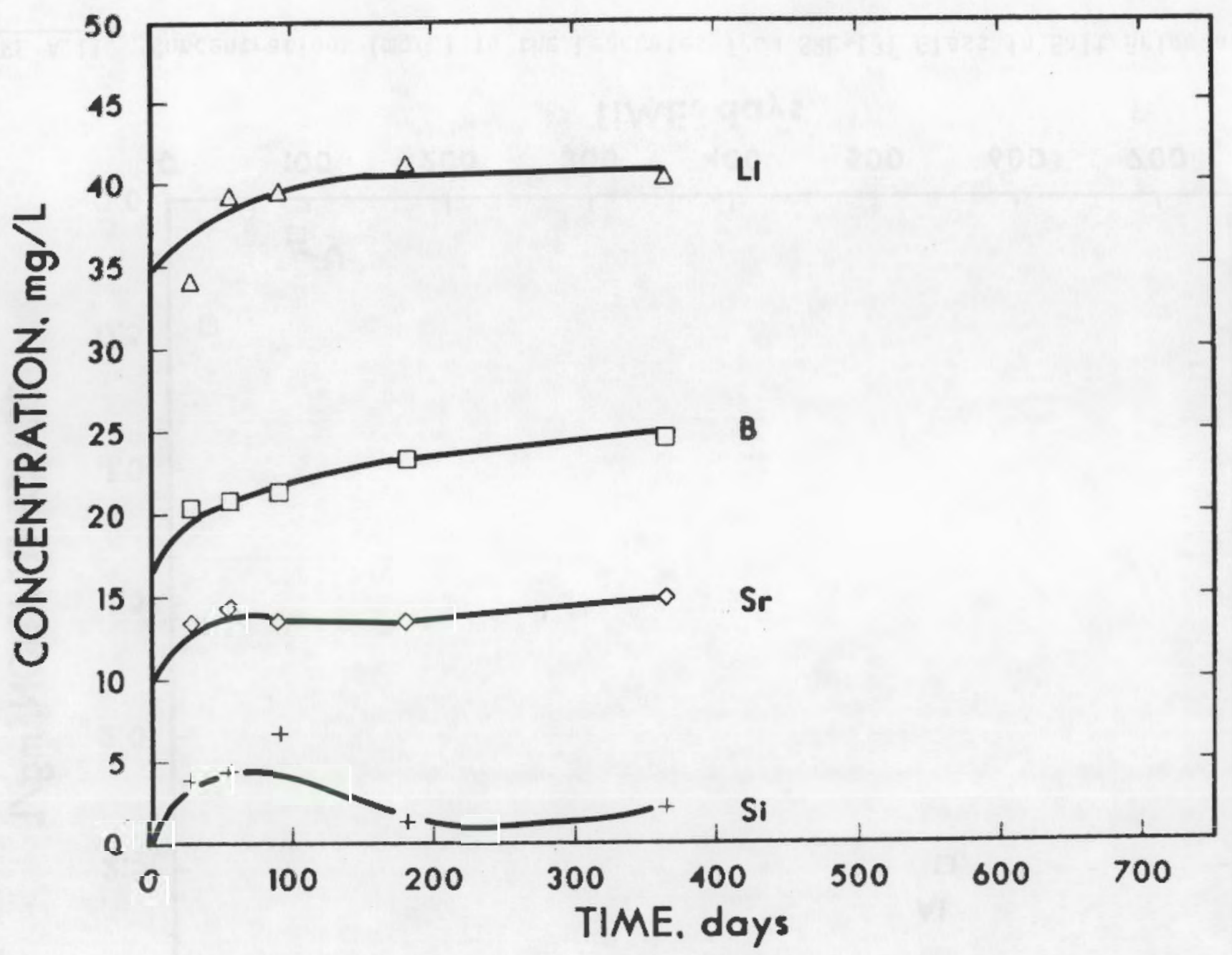

FIGURE A.12. Concentrations $\left(\mathrm{mg} / \mathrm{L}\right.$ ) in the Leachates from SRL-131 Glass in Salt Brine at $90^{\circ} \mathrm{C}$ 


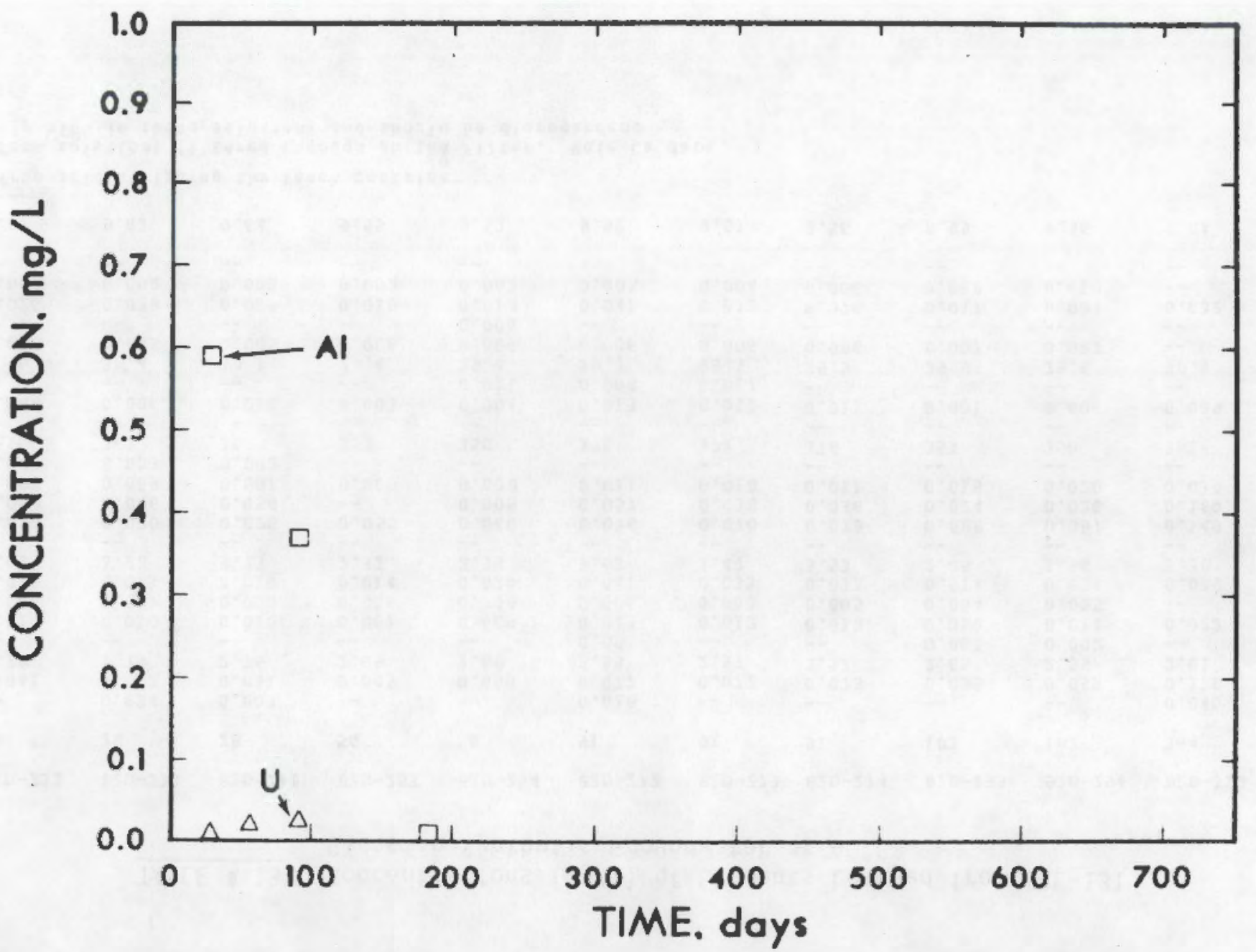

FIGURE A.13. Concentrations $(\mathrm{mg} / \mathrm{L})$ in the Leachates from SRL-131 Glass in Salt Brine at $90^{\circ} \mathrm{C}$ 
TABLE A.13. Concentrations ( $\mathrm{mg} / \mathrm{L}$ ) of Elements Leached from SRL-131

Glass in Synthetic Groundwater at $40^{\circ} \mathrm{C}$

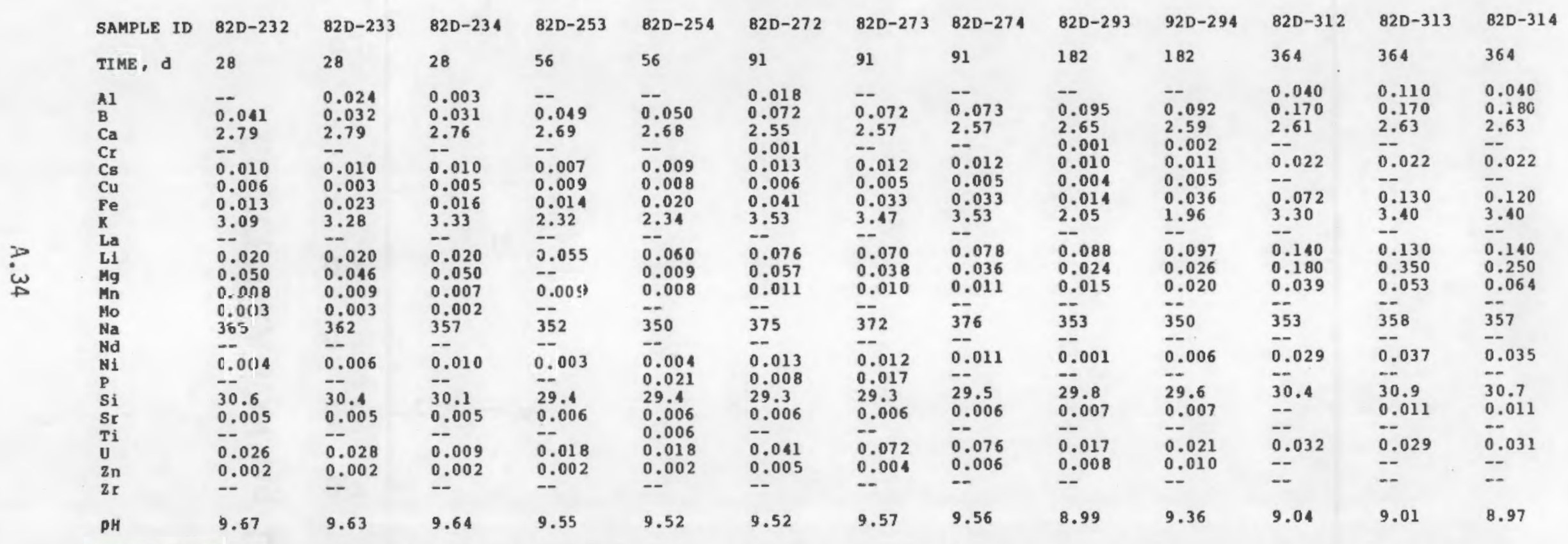

$S$ - results from acid stripping the leach container

$\begin{aligned} & \text { F } \text { results from solutions filtered through an } 180^{\circ} \text { fliter. Note ca data } \\ & \text { are usually high in these solutions and should be disregarded. }\end{aligned}$ 
TABLE A.14. Normalized Elemental Mass Loss $\left(\mathrm{g} / \mathrm{m}^{2}\right)$ for SRL-131 Glass in Synthetic Groundwater at $40^{\circ} \mathrm{C}$

\begin{tabular}{|c|c|c|c|c|c|c|c|c|c|c|c|c|c|}
\hline SAKPLE ID & $82 \mathrm{D}-232$ & $82 \mathrm{D}-233$ & $82 \mathrm{D}-234$ & $82 \mathrm{D}-253$ & $82 D-254$ & $82 \mathrm{D}-272$ & $82 \mathrm{D}-273$ & $82 \mathrm{D}-274$ & $82 D-293$ & $82 D-294$ & $82 \mathrm{D}-312$ & $82 D-313$ & B2D-314 \\
\hline Time, d & 28 & 28 & 28 & 56 & 56 & 91 & 91 & 91 & 182 & 182 & 364 & 364 & 364 \\
\hline Al & $\overline{0.13}$ & $\begin{array}{l}0.099 \\
0.098\end{array}$ & $\overline{0.095}$ & $\overline{0.15}$ & $\overline{0.16}$ & $\begin{array}{l}0.096 \\
0.18\end{array}$ & $\overline{0.18}$ & $\overline{0.19}$ & $\overline{0.26}$ & $\overline{0.25}$ & $\begin{array}{l}0.25 \\
0.56\end{array}$ & 0.68 & 0.25 \\
\hline $\begin{array}{l}\mathrm{B} \\
\mathrm{Ca}\end{array}$ & 0.47 & 0.47 & 0.067 & -- & -- & -10 & -18 & & 0.13 & 0.25 & 0.56 & 0.56 & $\begin{array}{c}0.59 \\
--\end{array}$ \\
\hline Cr & -- & $-\ddot{n}$ & -- & -- & -- & -- & $=-$ & -- & - & -- & -- & $\cdots$ & -- \\
\hline $\mathrm{Cs}$ & 0.35 & 0.35 & 0.35 & 0.25 & 0.32 & 0.46 & 0.42 & 0.42 & 0.35 & 0.39 & 0.78 & 0.78 & 0.76 \\
\hline $\begin{array}{l}\text { Cu } \\
\mathrm{Fe}\end{array}$ & $\begin{array}{l}0.83 \\
0.0065\end{array}$ & $\overline{0.016}$ & $\begin{array}{l}0.42 \\
0.0095\end{array}$ & $\begin{array}{l}2.09 \\
0.0075\end{array}$ & $\begin{array}{l}1.67 \\
0.013\end{array}$ & $\begin{array}{l}2.09 \\
0.026\end{array}$ & $\begin{array}{l}1.67 \\
0.018\end{array}$ & $\begin{array}{l}1.67 \\
0.018\end{array}$ & 1.25 & $\begin{array}{l}1.67 \\
0.021\end{array}$ & $\overline{0.033}$ & $\overline{0.091}$ & 0 \\
\hline $\mathrm{K}$ & $-\infty$ & - & $=$ & - & $=$ & 6.52 & 0.5 & 6.52 & -- & -- & .. & $10^{\circ 1}$ & $\begin{array}{c}0.081 \\
10\end{array}$ \\
\hline $\begin{array}{l}\text { La } \\
\text { Li }\end{array}$ & $\overline{0.064}$ & 0.064 & $\overline{0.064}$ & 0.26 & $\overline{0.29}$ & 0.34 & $\overline{0.3}$ & $\overline{-1}$ & 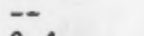 & -- & -- & - & -- \\
\hline Mg & 0.17 & 0.11 & 0.17 & -- & $=$ & 0.24 & 0.3 & $\begin{array}{l}0.35 \\
--\end{array}$ & 0.4 & 0.45 & 0.78 & 0.72 & 0.78 \\
\hline$M n$ & 0.028 & 0.032 & 0.025 & 0.032 & 0.028 & 0.027 & 0.023 & 0.027 & 0.042 & 0.061 & $\overline{0.15}$ & 2.21 & 0.87 \\
\hline Mo & -- & -- & $=-$ & -- & - & $=-$ & $=$ & $\overline{-}$ & -- & -- & -- & -- & --24 \\
\hline $\mathrm{Na}$ & 10 & 7.3 & 2.74 & -- & $\sim$ & 178 & 176 & 179 & 158 & 155 & 0.46 & 5.02 & 4.11 \\
\hline $\begin{array}{l}\text { Nd } \\
\text { Ni }\end{array}$ & $\overline{0.033}$ & 0.05 & 0.083 & $\overline{0.025}$ & $\overline{0.033}$ & $\overline{0.11}$ & 0.099 & $\overline{0.091}$ & 0.0083 & $\overline{0.05}$ & $\overline{0.24}$ & $-\overline{31}$ & $-\overline{7}^{2}$ \\
\hline $\mathbf{P}$ & -- & -- & -- & -- & 2.98 & $m$ & -- & -- & & -- & -2 & 0.31 & 0.29 \\
\hline $\begin{array}{l}\text { Si } \\
\text { Sr }\end{array}$ & $\begin{array}{l}0.75 \\
0.084\end{array}$ & $\begin{array}{l}0.64 \\
0.084\end{array}$ & $\begin{array}{l}0.47 \\
0.084\end{array}$ & $\begin{array}{l}0.083 \\
0.17\end{array}$ & $\begin{array}{l}0.083 \\
0.17\end{array}$ & $\begin{array}{l}0.25 \\
0.25\end{array}$ & $\begin{array}{l}0.25 \\
0.25\end{array}$ & $\begin{array}{l}0.36 \\
0.25\end{array}$ & $\begin{array}{l}0.53 \\
0.34\end{array}$ & $\begin{array}{l}0.42 \\
0.34\end{array}$ & 0.19 & $\begin{array}{l}0.47 \\
0.93\end{array}$ & $\begin{array}{l}0.36 \\
0.93\end{array}$ \\
\hline$T i$ & -- & -- & -- & -- & 0.12 & -- & -- & z-0 & -- & -- & -- & -- & -- \\
\hline U & 0.18 & 0.2 & 0.063 & 0.13 & 0.13 & 0.28 & 0.5 & 0.53 & 0.12 & 0.14 & 0.22 & 0.21 & 0.22 \\
\hline $2 n$ & -- & -- & -- & -- & -- & -- & -- & -- & -- & -- & -- & -- & -- \\
\hline $\mathbf{z r}$ & -- & -- & -- & -- & -- & -- & -- & - & - & -- & -- & -- & -- \\
\hline
\end{tabular}

$S=$ results from acid stripping the leach container

$F=$ results fro solutions filtered through an $18 \hat{f}$ fllter. Note $c a$ data are usually high in these solutions and should be disregarded. 
TABLE A.15. Concentrations (mg/L) of Elements Leached from SRL-131

Glass in Synthetic Groundwater at $90^{\circ} \mathrm{C}$

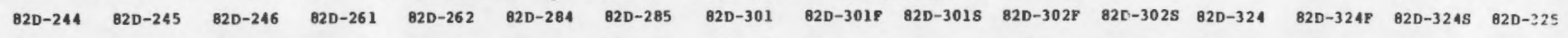

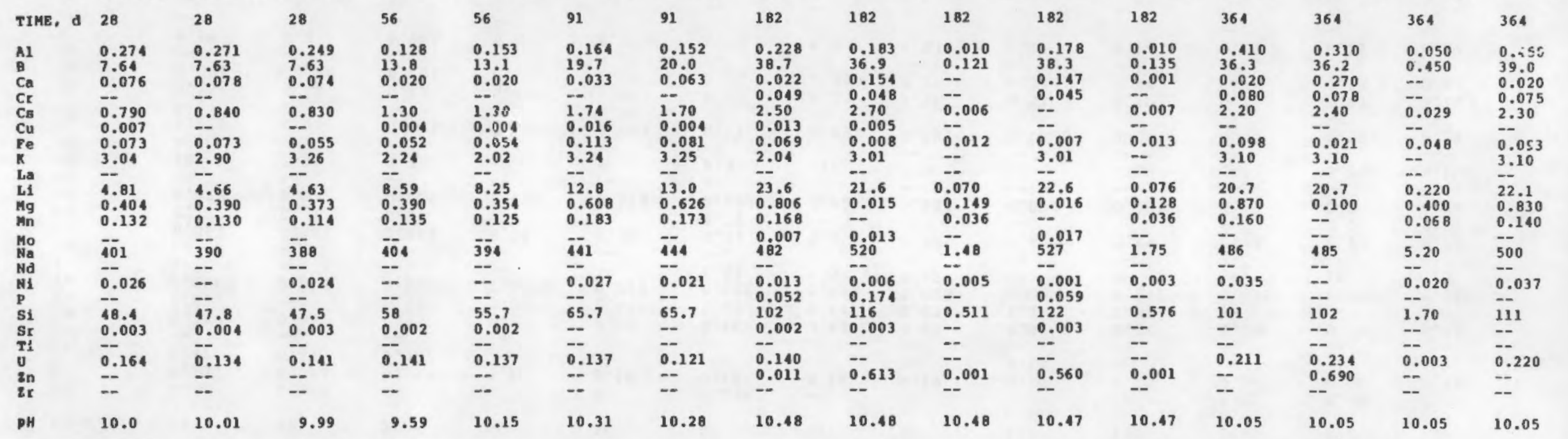

S. results frow acid stripping the leach contalner

F - results from solutions filtered through an $16 \AA$ Miter.' Hote ca data are usually high in these solutions and should be disregarded. 
TABLE A.15. (contd)

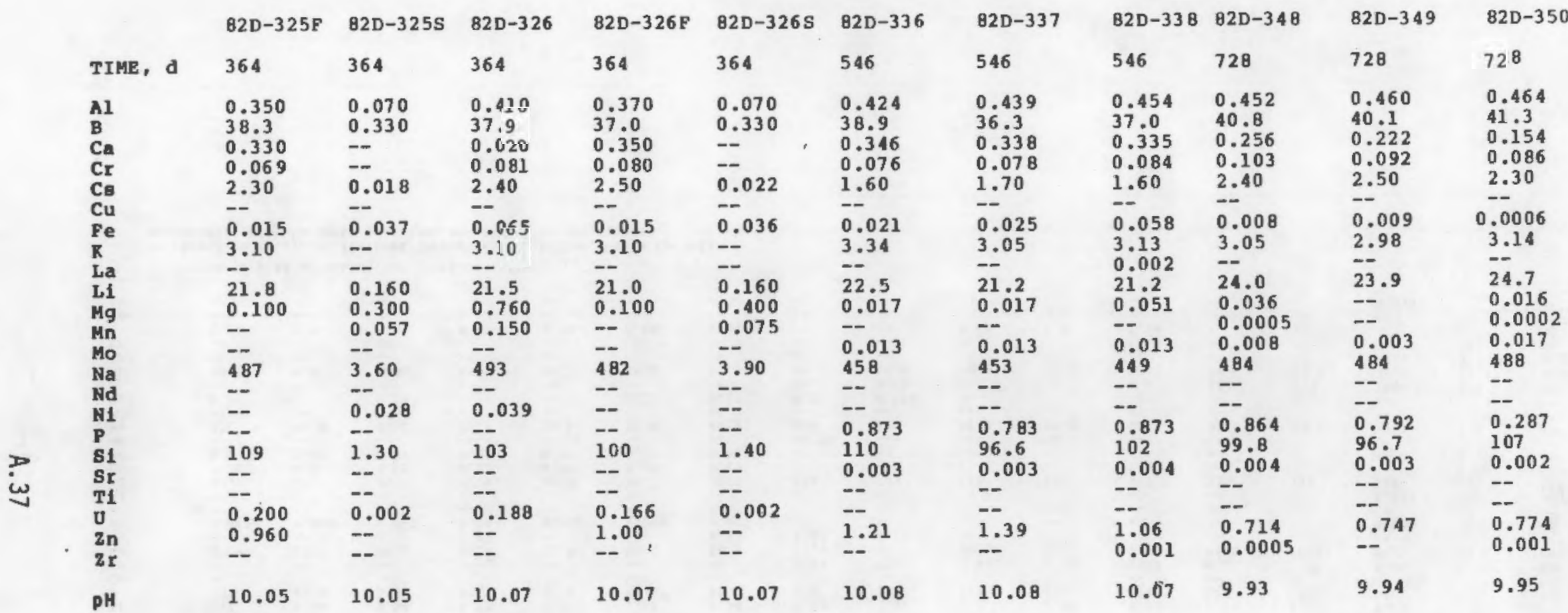

$S=$ results from acid stripping the leach container

$F=$ results from solutions filtered through an $18 \AA$ f 11 ter. Note Ca data are usually high in these solutions and should be disregarded. 
TABLE A.16. Normalized Elemental Mass Loss $\left(\mathrm{g} / \mathrm{m}^{2}\right)$ for SRL-131 Glass in Synthetic Groundwater at $90^{\circ} \mathrm{C}$

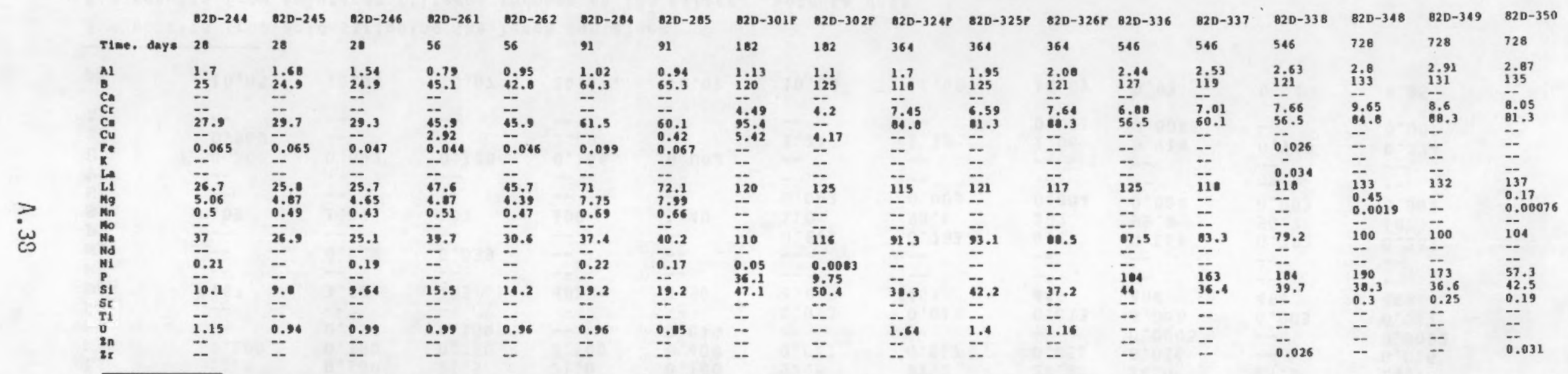

S- results froe acte stripping the leach contolner

- results from solutions flltered through on 10 i nilter. Mote ca date 


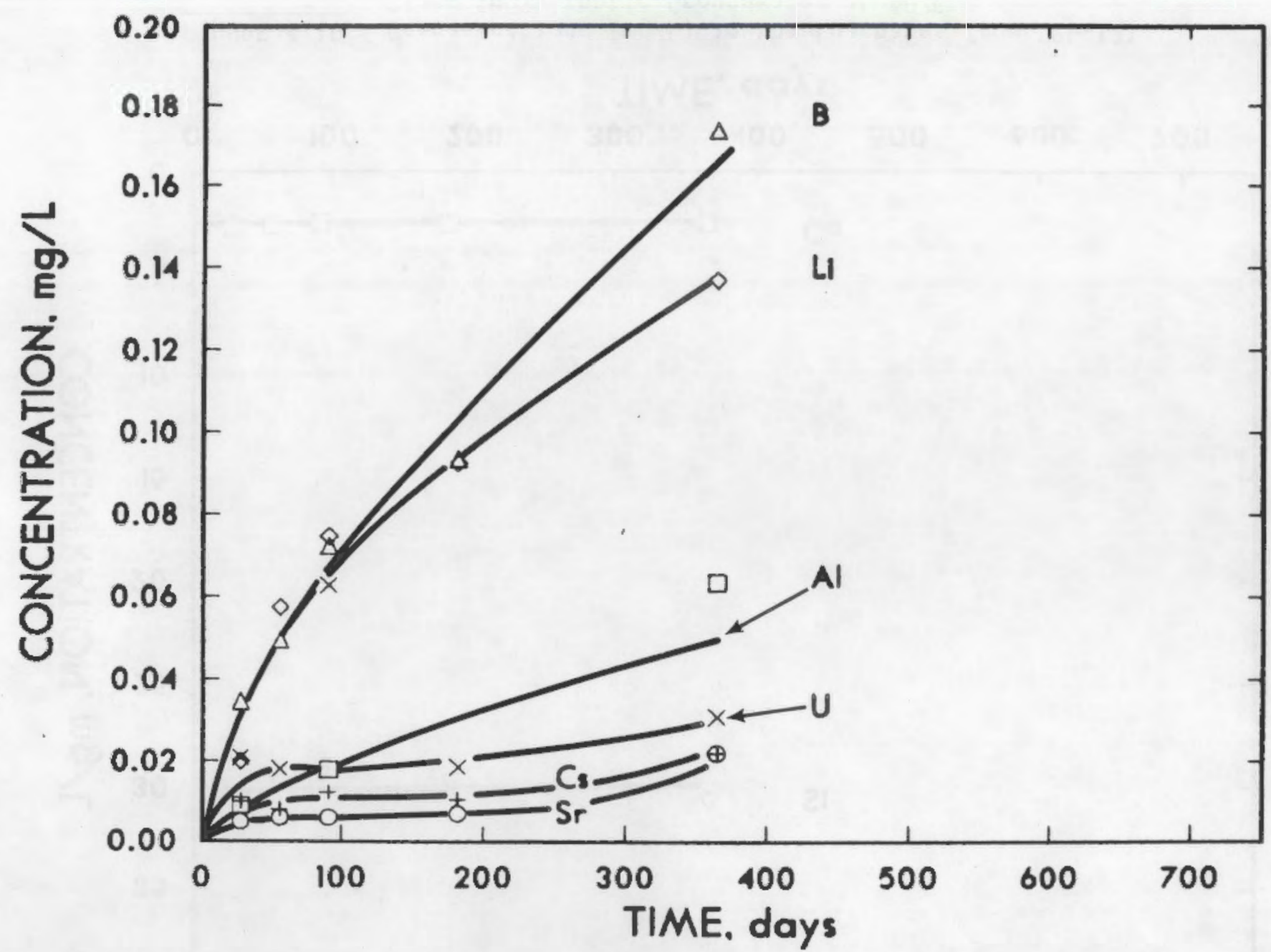

FIGURE A.14. Concentrations (mg/L) in the Leachates from SRL-131 Glass in Synthetic Groundwater at $40^{\circ} \mathrm{C}$ 


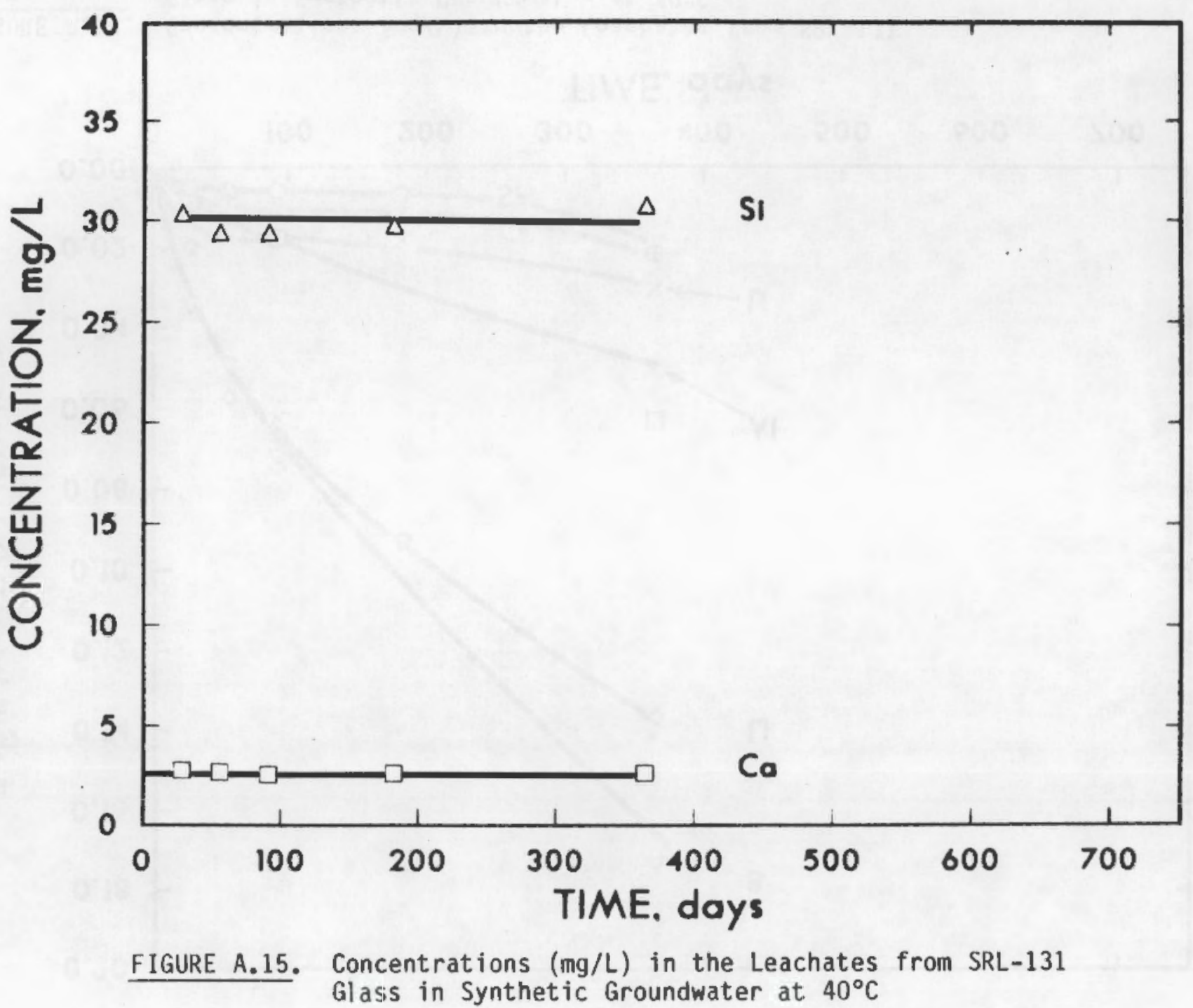




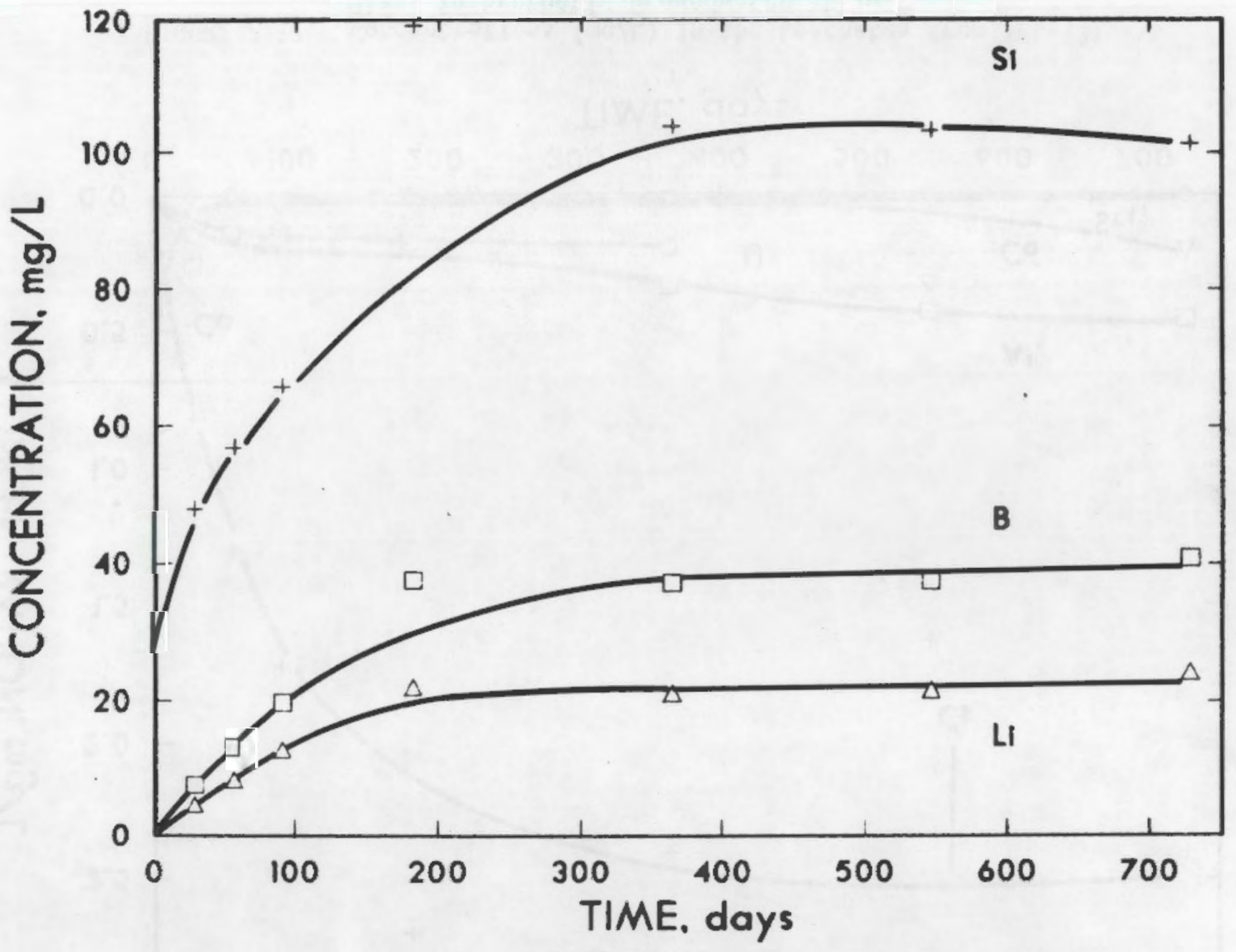

FIGURE A.16. Concentrations (mg/L) in the Leachates from SRL-131 Glass in Synthetic Groundwater at $90^{\circ} \mathrm{C}$ 


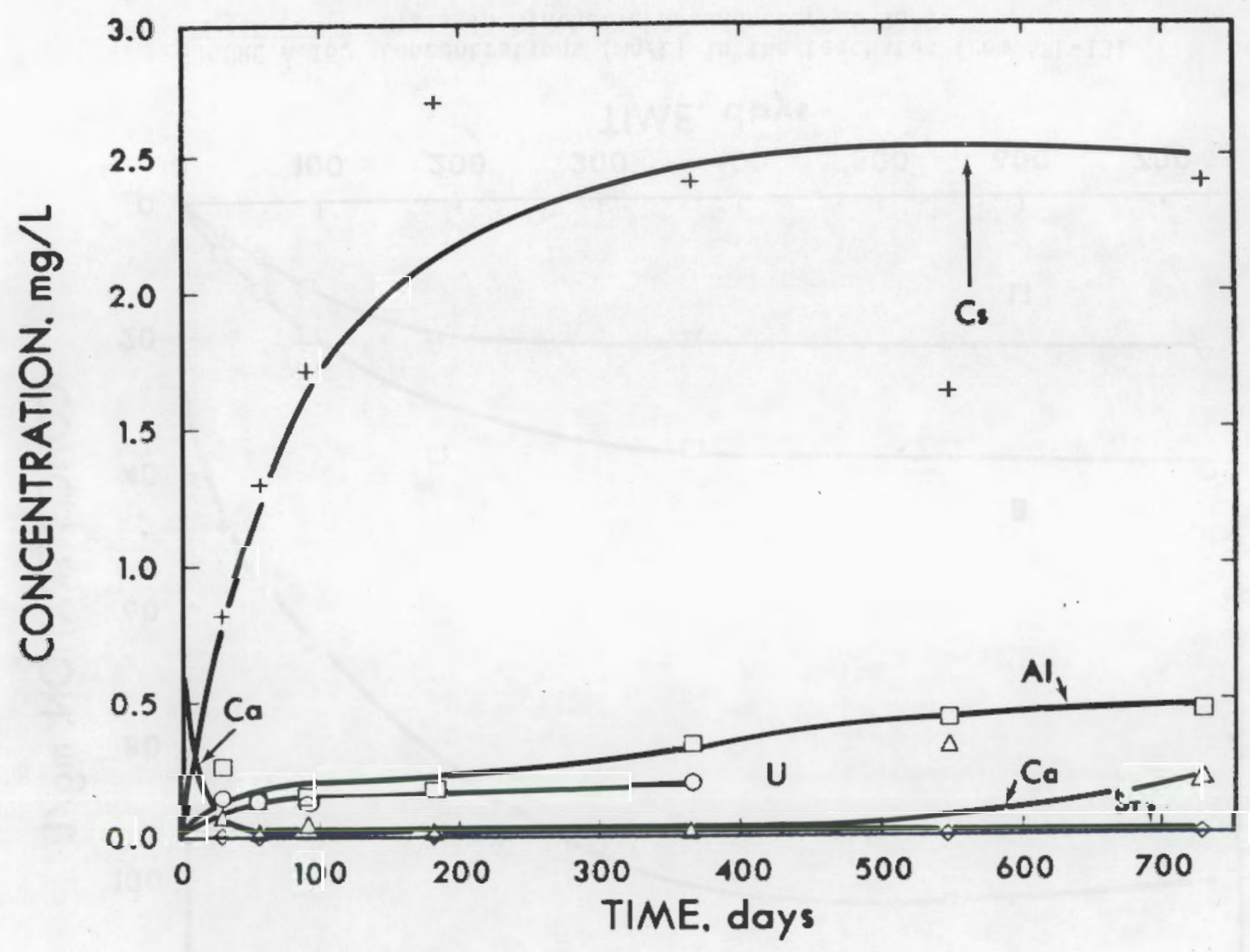

FIGURE A.17. Concentrations ( $\mathrm{mg} / \mathrm{L}$ ) in the Leachates from SRL-131 Glass in Synthetic Groundwater at $90^{\circ} \mathrm{C}$ 


\section{DISTRIBUTION}

No. of

Copies

OFFSITE

Carl Cooley

DOE Headquarters

$\mathrm{RW}-43$

Washington, DC 20545

R. D. Walton, Jr.

DOE Headquarters

DP-123, GTN

Washington, DC 20545

30 DOE Technical Information Center

Michael J. Bell

Nuclear Regulatory Commission

Washington, DC 20555

K. S. Kim

Nuclear Regulatory Commission

Washington, DC 20555

Or. H. E. Nuttall

Nuttall and Associates, Inc. 1445 Honeysuck le Drive, NE

Albuquerque, NM 87122

J. C. Haugen

DOE Chicago Operations office

9800 South Cass Avenue

Argonne, IL 60439

K. K. Hu

U.S. Department of Energy

Salt Repository Project Office

505 King Avenue

Columbus, $\mathrm{OH} 43201$

J. K. Bates

Argonne National Laboratory

9700 South Cass Avenue

Argonne, IL 60439
No. of

Copies

W. B. Seefeldt

Argonne National Laboratory g700 South Cass Avenue

Argonne, IL 60439

M. G. Seittz

Argonne National Laboratory

9700 South Cass Avenue

Argonne, IL 60439

M. J. Steindler

Argonne National Laboratory

9700 South Cass Avenue

Argonne, IL 60439

D. E. Clark

Office of Nuclear Waste Isolation

Battelle Project Management Division

P.0. Box 16594

Columbus, OH 43216-6594

J. F. Kircher

office of Nuclear Waste Isolation

Battelle Project Management Division

P.0. Box 16594

Columbus, $\mathrm{OH} \quad 43216-6594$

E. J. Hennelly

E.I. duPont deNemours and Co., Inc.

Savannah River Laboratory

Aiken, SC 29808-0001

C. M. Jantzen

E.I. duPont deNemours and Co., Inc.

Savannah River Laboratory

Aiken, SC 29808-0001 
No. of

Copies

M. J. Plodinec (6)

E.I. duPont deNemours and Co., Inc.

Savannah River Laboratory

Aiken, SC 29808-0001

J. A. Stone

E.I. duPont deNemours and Co., Inc.

Savannah River Laboratory

Aiken, SC 29808-D001

G. G. Wicks

E.I. duPont deNemours and Co., Inc.

Savannah River Laboratory

Aiken, SC 29808-0001

D. Isherwood

Lawerence Livermore National Laboratory

University of California

P.0. Box 808

Livermore, CA 94550

V. Oversby

Lawrence Livermore National Laboratory

University of California

P.0. Box 808

Livermore, CA 94550

L. Brush

Sandia National Laboratory

P.0. Box 5800

Albuquerque, NM 87107

M. A. Molecke

Sandia National Laboratory

P.0. Box 5800

Albuquerque, NM 87107

A. Barkatt

Vitreous State Laboratory

Keane Hall

Catholic University of America

Washington, DC 20064
No. of

Copies

P. B. Macedo

Vitreous State Laboratory

Keane Hall

Catholic University of America

P.0. Box 1663

Washington, OC 20064

D. E. Clark

University of Florida.

Department of Material Science and Engineering

College of Engineering

Gainesville, FL 32611

L. L. Hench

University of Florida

Department of Material Science and Engineering

College of Engineering

Gainesville, FL 32611

Dr. R. C. Ewing

Department of Geology

University of New Mexico

Albuquerque, NM 87131

W. B. White

Pennsylvania State University

University Park, PA 16802

H. Barnes

Pennsylvania State University

University Park, PA 16802

J. L. Knabenschuh

West Valley Nuclear Services

Co., Inc.

P.0. Box 191

West Valley, NY 14171-0191

J. M. Pope

West Valley Nuclear Services

Co., Inc.

P.0. Box 191

West Valley, NY 14171-0191 
No. of

Copies

A. J. Machiels

EPRI

P.0. Box 10412

Palo Alto, CA 94303

FOREIGN

K. Harvey

Atomic Energy of Canada

Pinawa, Manitoba, ROE ILO

Canada

Lawrence Johnson

Atomic Energy of Canada

Pinawa, Manitoba, ROE ILO

Canada

Peter J. Hayward

Atomic Energy of Canada

Pinawa, Manitoba, ROE 1LO

Canada

Dr. Werner Lutze

Hahn-Meitner Institut fur Kernforschung

Glienicker Strasse 100

D1000 Berlin 39

Federal Republic of Germany

Dr. Bernd Grambow

Hahn-Meitner Institut fur Kernforschung

Glienicker Strasse 100

D1000 Berlin 39

Federal Republic of Germany

Or. Edwin Schiewer

Hahn-Meitner Institut fur Kernforschung

Glienicker Strasse 100

D1000 Berlin 39

Federal Republic of Germany

Or. Seichi Sato

Kyushu University

Department of Nuclear

Engineering

Fukuoka, Japan
No. of

Copies

Dr. Shang J. Liu

Radioactive Waste Management Division

Institute of Nuclear Energy Research

P.0. Box 3-27

Lung Tan, Taiwan 325

ONSITE

4 DOE Richland Operations Office

E. A. Bracken

M. W. Shupe

J. D. White

J. K. W. Wukelic

7 Rockwell Hanford Operations

J. Burnell

M. J. Kupfer

E. H. Randklev

P. F. Salter

W. W. Schulz

M. J. Smith

D. A. Turner

54 Pacific Northwest Laboratory

M. 3. Apted

0. J. Bradley

T. D. Chikalla

D. G. Coles

3. R. Divine

F. N. Hodges

J. H. Jarrett

C. A. Knox

M. R. Kreiter

K. M. Krupka

W. L. Kuhn

J. M. Latkovich

R. 0. Lokken

J. L. McElroy

G. L. McVay

G. B. Mellinger

J. E. Mendel

L. R. Pederson (10)

R. 0 . Peters 
No. of

Copies

D. Rai

W. A. Ross

R. J. Serne

J. W. Shade
No. of

Copies

S. C. Slate

D. M. Strachan (10)

Publishing Coordination (2)

Technical Information (5)

Distr.4 